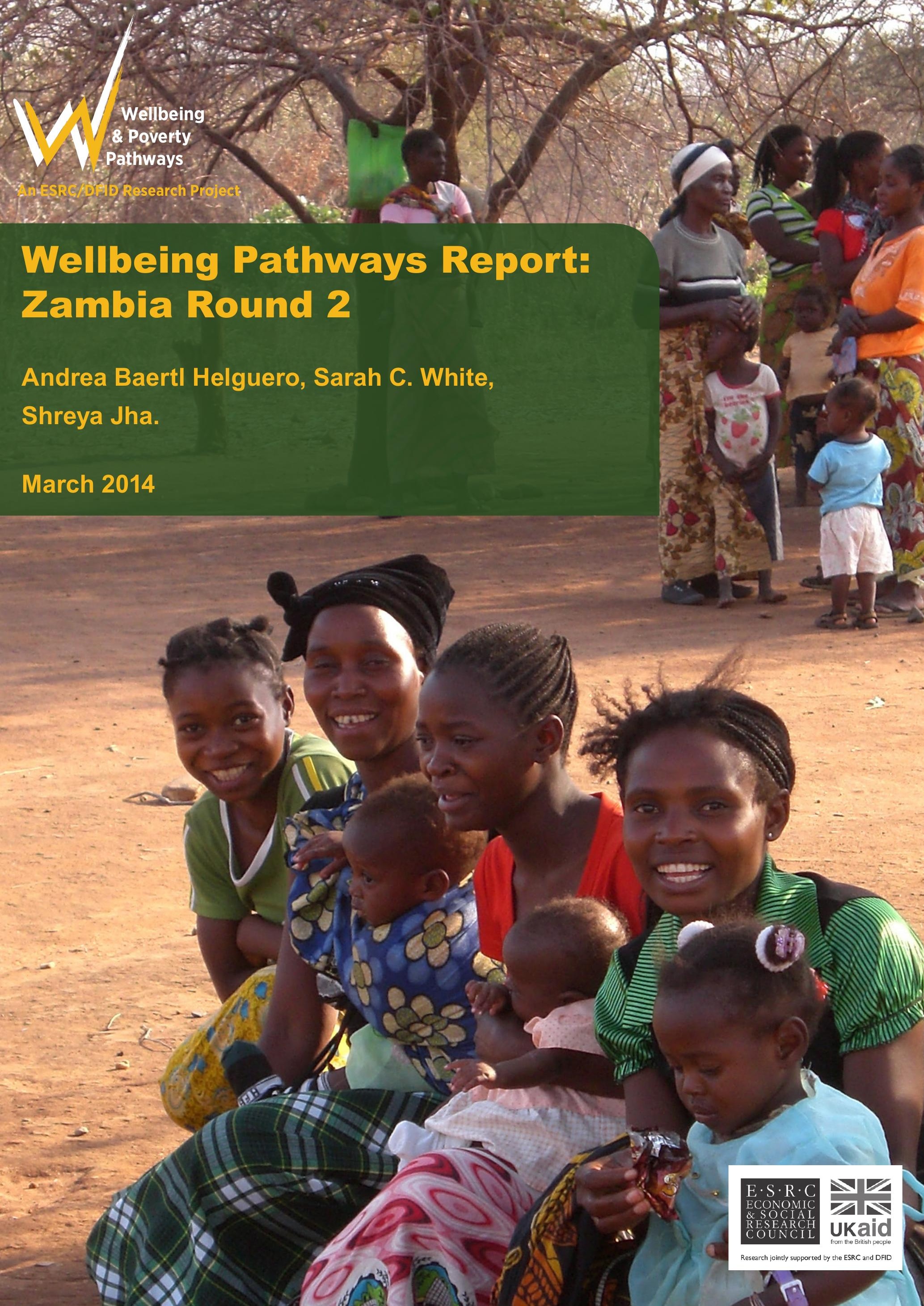




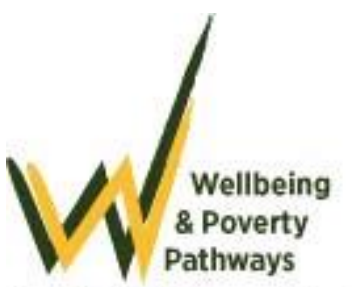

An ESRC/DFID Research Project

\section{Wellbeing Pathways Report: Zambia Round 2}

Andrea Baertl Helguero, Sarah C. White, Shreya Jha

March 2014

\section{Acknowledgements}

This work was supported by the Economic and Social Research Council/Department For International Development Joint Scheme for Research on International Development (Poverty Alleviation) grant number RES-167-25-0507 ES/H033769/1.

Many thanks are due to the other members of the Wellbeing Pathways Team whose work this paper reflects: UK-based, Stanley Gaines Jr., Zambia based, Hodi and Jonnathan Mtonga, Joseph Kajiwa, Stephen Kalio, Kelvin Matesamwa, Goodson Phiri. 


\section{Contents}

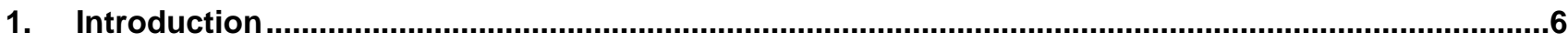

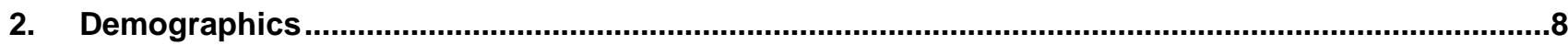

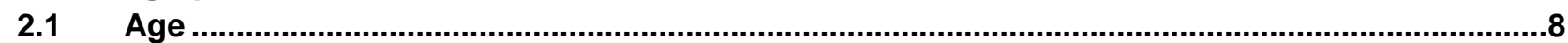

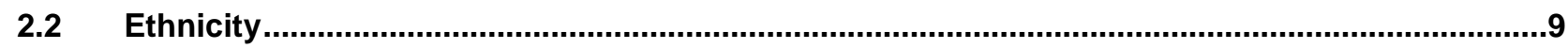

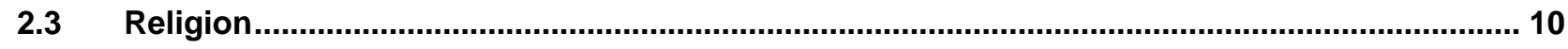

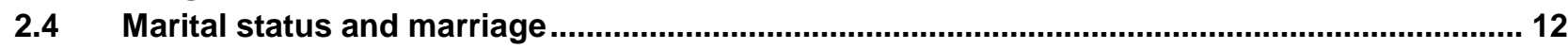

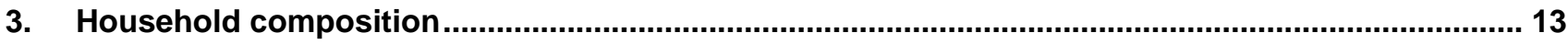

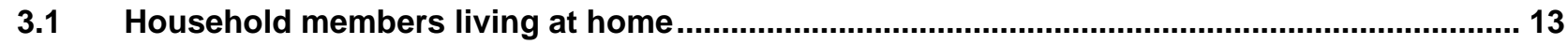

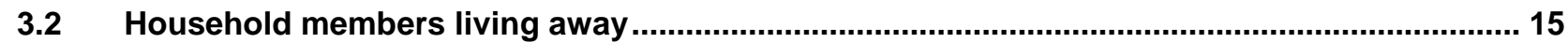

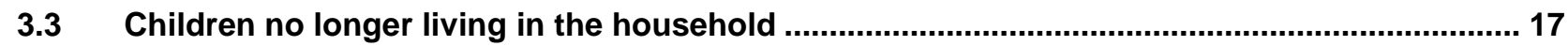

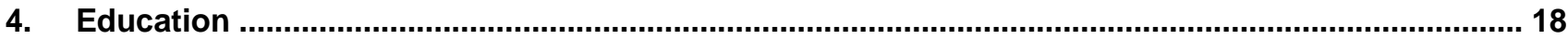

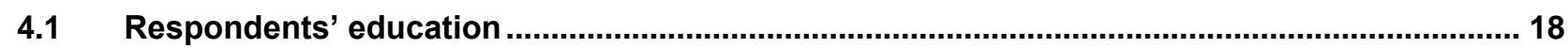

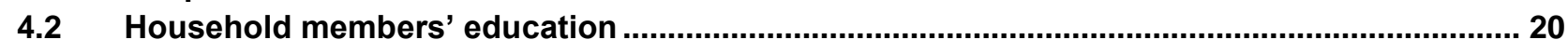

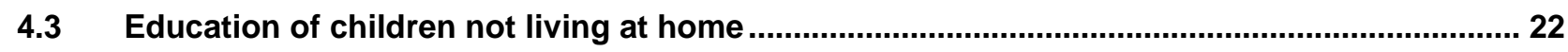

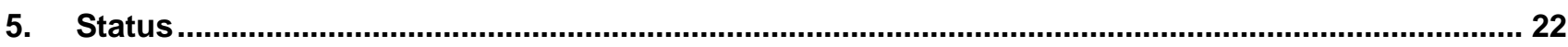

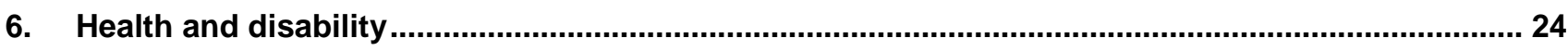

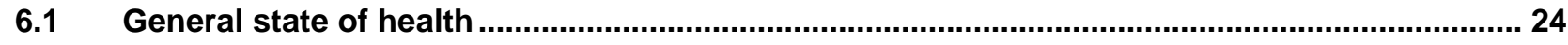

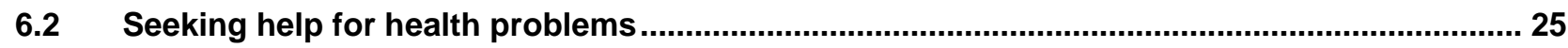

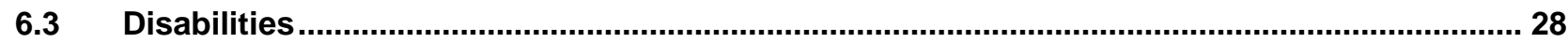

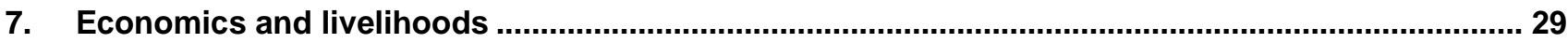

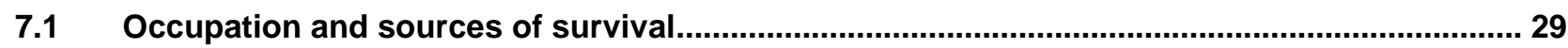

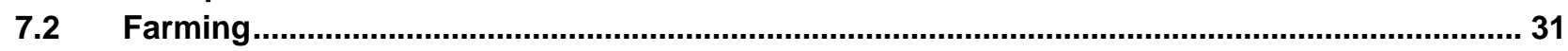

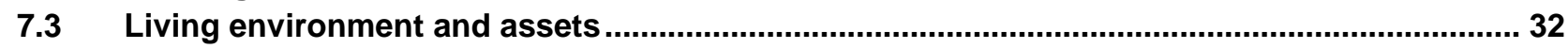

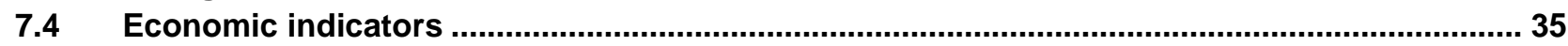

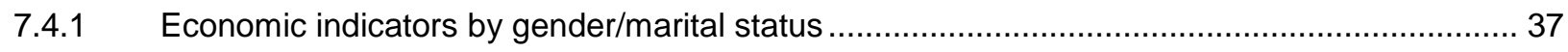

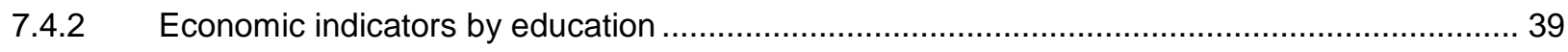

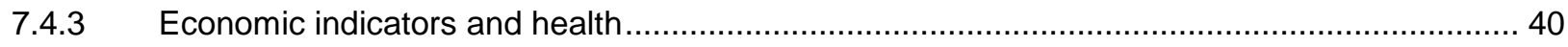

7.4.4 Economic indicators by household size and type .......................................................... 40

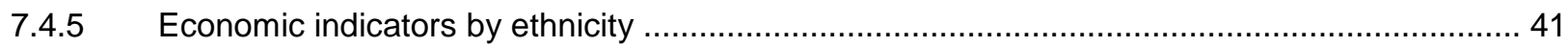

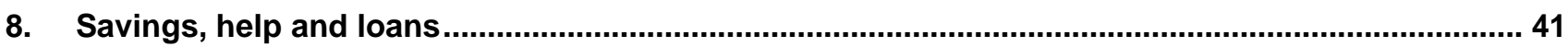

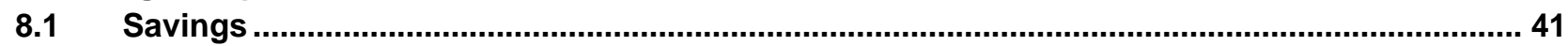

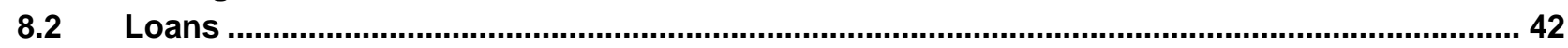

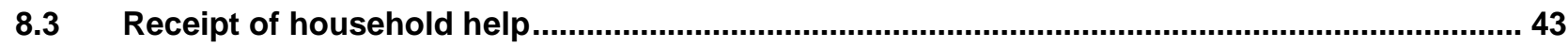

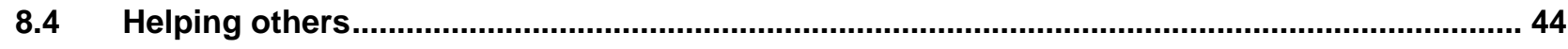

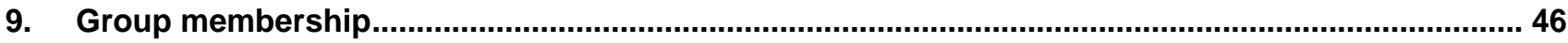

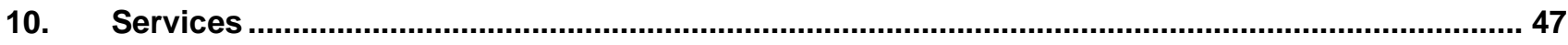

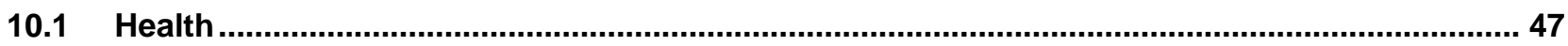

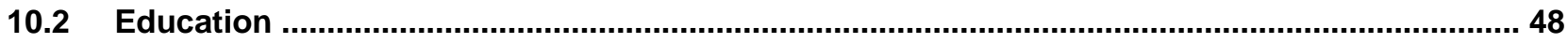

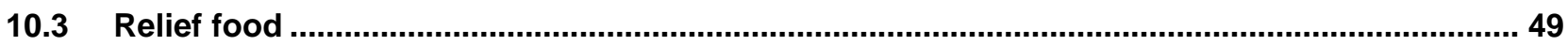

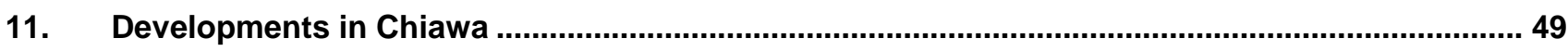

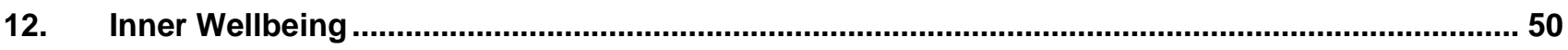

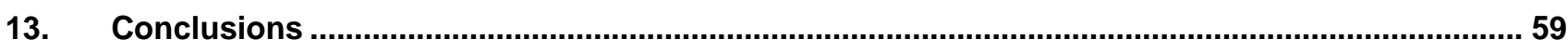

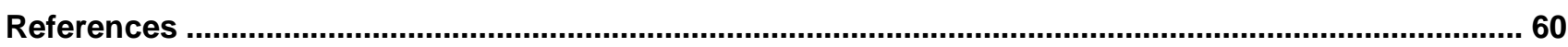




\section{Tables}

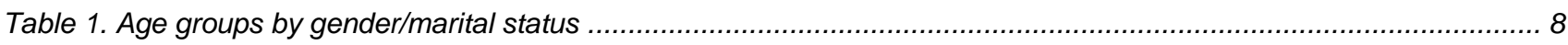

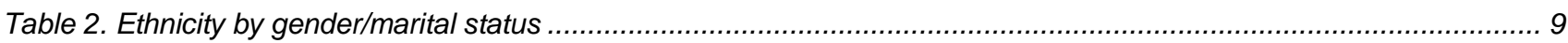

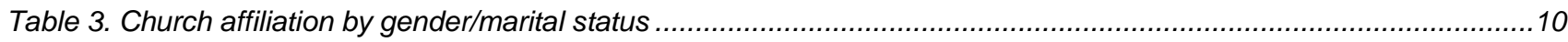

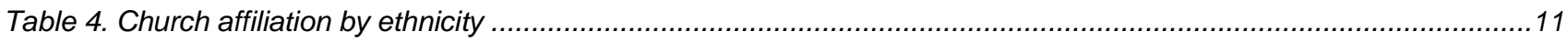

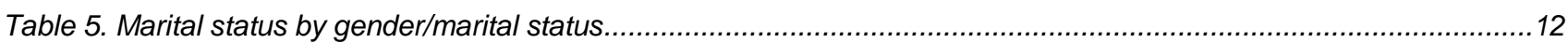

Table 6. Number of marriages that ended in desertion/divorce by gender/marital status .............................................13

Table 7. Number of marriages that ended in death by gender/marital status.............................................................13

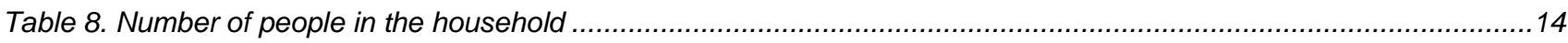

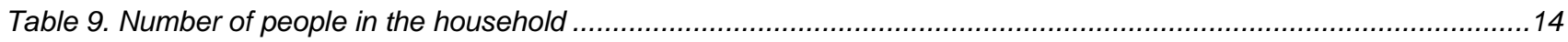

Table 10. Member's relation to household head by age groups (below 19 years old) …...............................................15

Table 11. Household members living away relation to household head away by gender .............................................16

Table 12. Household members living away: place of residence by gender ..................................................................17

Table 13. Sons or daughters not living at home: residence by gender ..................................................................18

Table 14. School level reached by gender/marital status............................................................................... 19

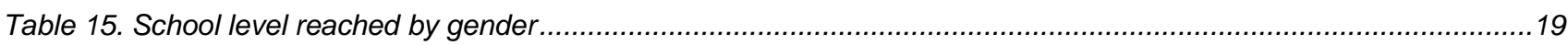

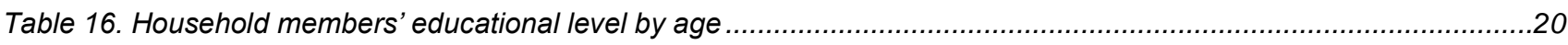

Table 17. Household members' educational level by gender (0-19 years old) ............................................................21

Table 18. Household members' educational level by gender (20 years old and older) ...............................................21

Table 19. Sons and daughters not living at home: education by gender...............................................................22

Table 20. Household member with special position in the community by gender/marital status....................................22

Table 21. Respondent with special position in the community by gender/marital status ..............................................23

Table 22. Household member with special position: Relation to household head by gender..........................................23

Table 23. Household member with special position: Position by gender …............................................................24

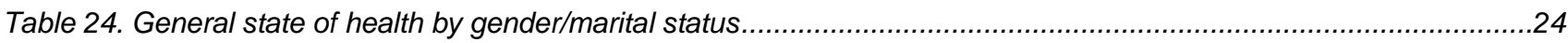

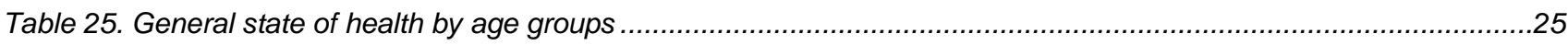

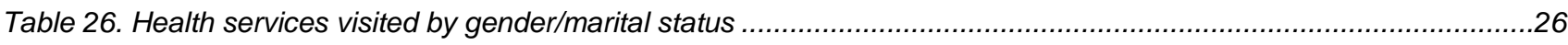

Table 27. Reason for visiting health service by health service ..............................................................................27

Table 28. Household member with most recent health problem .........................................................................28

Table 29. Impact on life by gender/marital status for respondents reporting functional impairment................................28

Table 30. Household member with disability: relation to household head by gender..................................................29

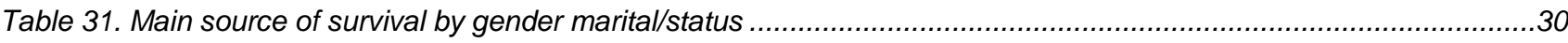

Table 32. Responsibility of source of survival by gender/marital status .....................................................................31

Table 33. Distribution of crops planted by gender/marital status......................................................................... 
Table 34. Amount of maize harvested by gender/marital status 32

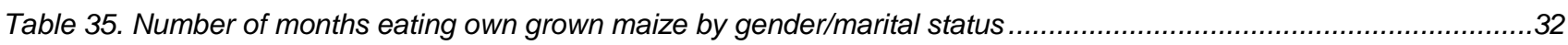

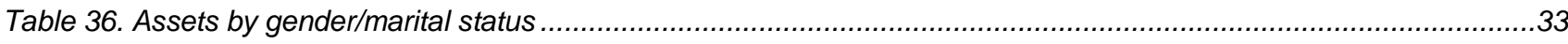

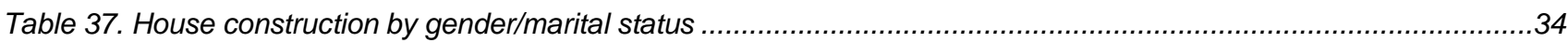

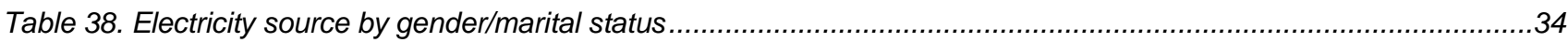

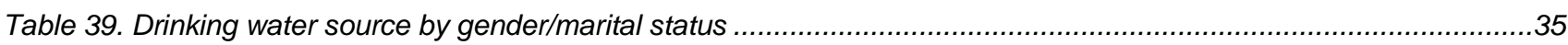

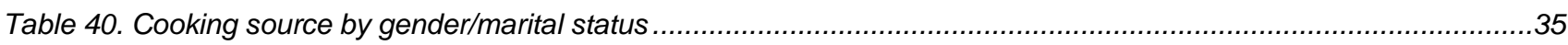

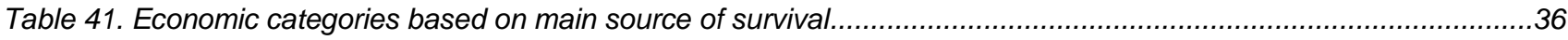

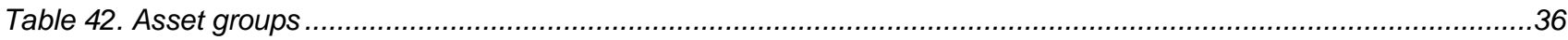

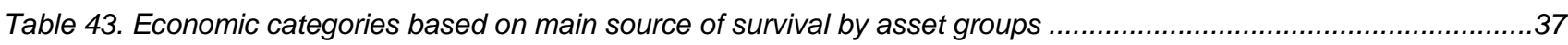

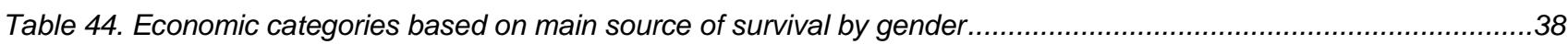

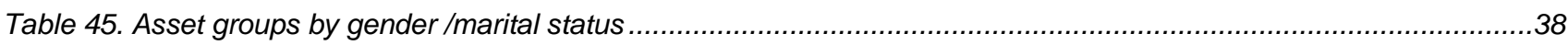

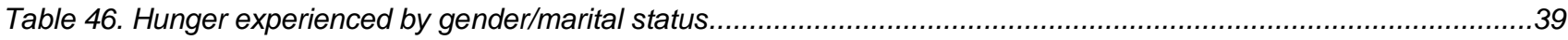

Table 47. Economic categories based on main source of survival by gender /marital status .......................................39

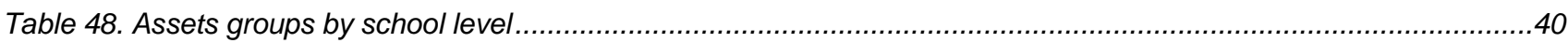

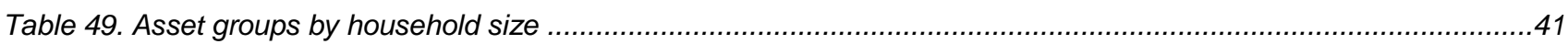

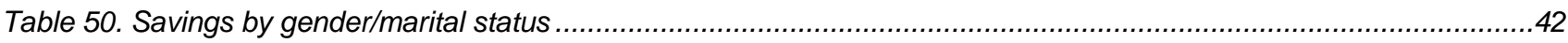

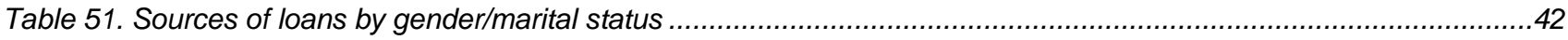

Table 52. Reasons for not taking a loan by gender/marital status .................................................................43

Table 53. Sources of help received by gender/marital status ..........................................................................43

Table 54. Destination of help received by gender/marital status............................................................................44

Table 55. Help given for household needs by gender/marital status............................................................44

Table 56. Destination of help given for household needs by gender/marital status ................................................45

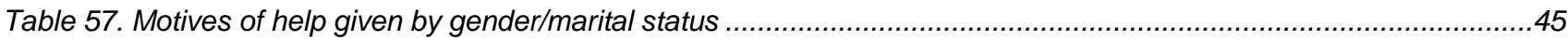

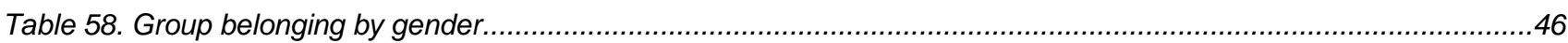

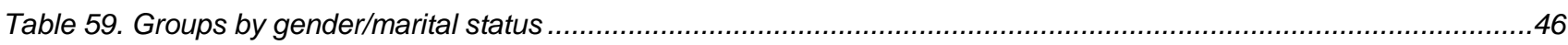

Table 60. Satisfaction with available health services by gender/marital status ....................................................47

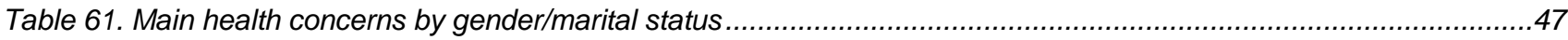

Table 62. Satisfaction with available education by gender/marital status ...........................................................48

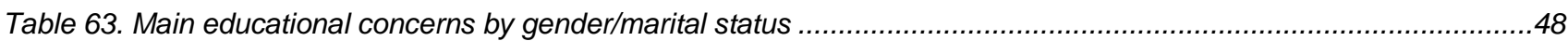

Table 64. Knowledge of new developments by gender/ marital status ..................................................................49

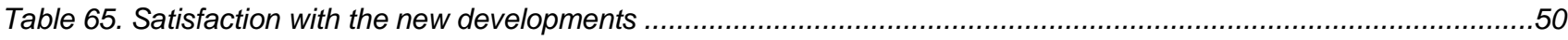

Table 66. Personal economic assessment by gender/marital status ...............................................................

Table 67. Correlation personal economic assessment with well-being domains ...................................................51 
Table 68. Comparison of standard of living with five years ago by gender/marital status .52

Table 69. Correlations comparison of standard of living five years ago with well-being domains ....................................52

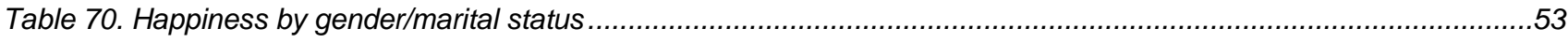

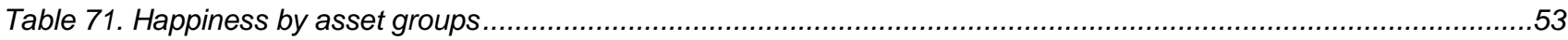

Table 72. Happiness by economic categories based on main source of survival ...................................................53

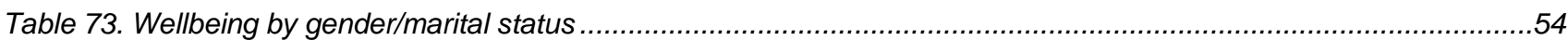

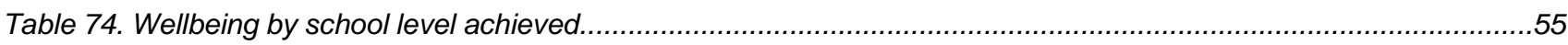

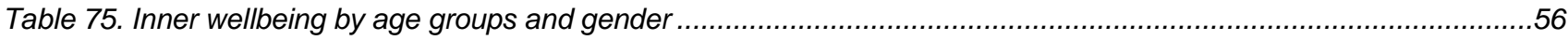

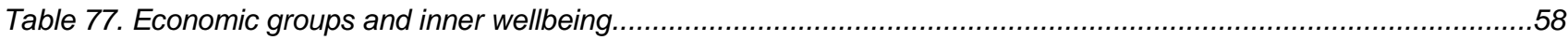

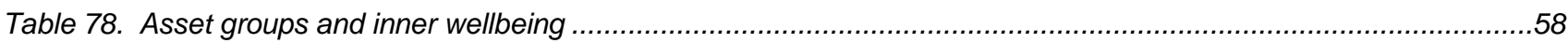




\section{Introduction}

This report presents the findings from the second round of fieldwork carried out in Chiawa, Zambia from August to October 2012 as part of the Wellbeing and Poverty Pathways research project. This project has developed a multi-dimensional model of wellbeing which incorporates both subjective perspectives and objective indicators, exploring how people understand and experience wellbeing and how this affects movement into or out of poverty.

Chiawa is a Game Management Area located $2 \frac{1}{2}$ hours from Lusaka, Zambia's capital, on the outskirts of the Lower Zambezi National Park. Despite its proximity to Lusaka, Chiawa has poor links to the rest of the country. Access means crossing the Kafue river using a ferry which only operates during the day, and there are no metalled roads in Chiawa. A very basic range of amenities can be accessed once across the river: a primary health centre, an agricultural extension office, a community development office, schools and churches. Yet even these services are not easily accessible to all, since there is no public transport.

The majority of the population lives in basic housing and makes a living from low or no technology agriculture, small businesses or jobs in the safari sector. There are a few large plantations which are commercially farmed, fully irrigated and electrically fenced to ensure a high quality crop protected from wild animals. Some employment is available as labour in the plantations and some, mainly young men, work in the luxury safari lodges. Malaria, and malnutrition are common. HIV/AIDS has been a major issue, but the clinic officer states that there are now few, if any, new cases of infection.

For the majority who are dependent on farming to survive, life is hazardous. Plantations and lodges occupy some of the best quality land, meaning local people have to shift into more marginal locations. The most fertile land is along the river banks (the matoro), but farming here is highly risky with the dual hazards of marauding animals and unpredictable flooding when water is released from dams upstream. To try to protect their fields from elephants and hippos, people often sleep in the fields at night, sometimes sustaining serious injuries themselves as a result. As it is a game management area the animals are protected, so the measures that local people can take to protect their crops are limited.

The second round of fieldwork was set in the context of great change on the horizon for the people of Chiawa. Much needed infrastructure developments are planned; a new bridge is under construction, and a new road is to be built which will connect Chiawa more closely to Lusaka on the one hand and the Zimbawean border on the other. Whilst these will undoubtedly reduce travel hardship and the sense of isolation that people experience, they could also set in train a series of other less desirable impacts. Improved access to the region will mean that the land is more attractive to investors, something which local people fear will impact further on their ability to live on productive farmland.

The questions used in this fieldwork gather objective and subjective data across key areas of life, or wellbeing 'domains.' The model of inner wellbeing (IWB) comprises seven domains: economic confidence, agency and participation, social connections, close relationships, competence and self-worth, physical and mental health, and finally, values and meaning. This model was derived through a combination of theoretical reflection and earlier field-testing both in Chiawa and a rural community in the Chhattisgarh state of central India. The survey has five questions (or items) for each domain which are designed to reflect different aspects of that domain. For each question respondents are asked to select one of five graduated answers on a one to five scale, with 1 being the lowest and 5 the highest. A domain score then is derived by averaging the scores from all the items in that domain. The particular questions which make up each domain were extensively grounded and piloted to ensure their relevance in the particular context. More information about our approach to wellbeing assessment and the theoretical model underpinning the fieldwork can be found in Briefing paper No. 1: An 
Integrated Approach to Assessing Wellbeing. ${ }^{1}$ while a more detailed account of the methodological development of the model is available in White et al., (2013).

The survey was comprised of three parts:

1. General demographic questions about the respondents and their household, including some health related questions.

2. Questions on inner wellbeing.

3. Economic and livelihoods questions, including questions about giving and receiving help, assets, loans, group membership, and access to services.

The survey ended with a general subjective economic assessment and a 'global' happiness question.

This report presents the descriptive statistics from the fieldwork and notes statistically significant differences by gender and marital status, age, education and other factors. The report starts by outlining the general demographic features of the sample, including gender, marital status, ethnicity, age and religion. This is followed by a demographic analysis of different levels of educational achievement, income and livelihoods, living environment, assets, savings, help and loans, status, health and other available services. The report finishes with a demographic analysis of people's subjective assessment of their economic position, and how 'happy' they feel.

The research project has been a process of learning across the different rounds of fieldwork, from Zambia in 2010, to India 2011, to Zambia 2012, and ultimately India 2013. Changes have therefore been made to the original survey design, meaning that direct comparisons should not be made with the first round of data collected in Chiawa in 2010. The reports from the first round of research in Zambia and in India contain more details on this learning and how the survey was redesigned in order to take it into account (White et al., $2012 a, b) .^{2}$

This report does not attempt to provide any wider contextual analysis or to draw conclusions and recommendations from the data. For these, please see Briefing Paper No. 2: The Politics of Wellbeing, Conservation and Development in Chiawa.

\footnotetext{
${ }^{1} \mathrm{http} / / /$ www.wellbeingpathways.org/images/stories/pdfs/briefing_papers/BP1rev-web.pdf

2 http://www.wellbeingpathways.org/resources/project-papers/146-zambia-round-1 and http://www.wellbeingpathways.org/images/stories/pdfs/working papers/indiatime1 report.pdf
} 


\section{Demographics}

In this second round of fieldwork in Chiawa, we surveyed 370 people: 148 married men, 166 married women, 52 single women and 4 single men (in total 152 men and 218 women). The single men have all been widowed or divorced since Round 1, two years earlier. Since single men are not a focus of the research, they will not be taken into account in any of the comparison of gender/marital status, but they are included in all of the other analysis when gender/marital status is not central to the analysis. 358 people were interviewed in both rounds of the research.

In total we have data from 229 households; 56 of those are households led by single people and 173 by married people. For 139 households we have data from both husband and wife, for the other 33 from only one spouse (25 women and 8 men). We also have one household in which the husband and 2 wives were surveyed. 52 of the single households are led by women, and 4 by men.

\section{$2.1 \quad$ Age}

The average age for all our respondents is 39 , the minimum 18 and the maximum is $84 .^{3}$ Married men range from 23 to 84, with an average age of 43; married women range from 18 to 67, with an average age of 36; single women range from 23 to 70 , with an average age of 42; single men range from 26 to 60 , with an average age of 39 .

In order to facilitate age comparisons among respondents and its influence on other variables, a new variable was created to differentiate between 5 age groups. These groups were created with two aims: one, to ensure an adequate distribution of respondents among groups, and two, to reflect different stages of adulthood. Of the 353 people that declared their age $18 \%$ are between 18 to 29 years old, $17 \%$ are between 30 to $34,20 \%$ are between 35 to $39,23 \%$ are between 40 and 49 , and $18 \%$ are 50 or more. ${ }^{4}$

The distribution of married men, married woman and single women between the age groups can be seen in Table 1. The most significant finding is how the percentage of married men and single women increases in the higher age groups, whilst the opposite happens for married women. $54 \%$ of the married men and $50 \%$ of the single women are over 40 years old, while only $30 \%$ of the married women are above 40 . A significantly larger percentage of married women (when compared with married men) are between 18 and 29 years old.

Table 1. Age groups by gender/marital status

\begin{tabular}{|c|c|c|c|c|c|c|c|c|c|}
\hline & & \multicolumn{6}{|c|}{ Gender/Marital Status* } & \multirow{2}{*}{\multicolumn{2}{|c|}{ Total }} \\
\hline & & \multicolumn{2}{|c|}{ Married Men } & \multicolumn{2}{|c|}{ Married Women } & \multicolumn{2}{|c|}{ Single Women } & & \\
\hline & & Count & $\begin{array}{c}\text { Column N } \\
\% \\
\end{array}$ & Count & $\begin{array}{c}\text { Column N } \\
\%\end{array}$ & Count & $\begin{array}{c}\text { Column N } \\
\% \\
\end{array}$ & Count & $\begin{array}{c}\text { Column N } \\
\%\end{array}$ \\
\hline \multirow{5}{*}{ Age groups } & 18 to 29 years & $16 \mathrm{a}$ & $11 \%$ & $44_{b}$ & $28 \%$ & $5 a, b$ & $11 \%$ & 65 & $19 \%$ \\
\hline & 30 to 34 years & $23_{a}$ & $16 \%$ & $32_{a}$ & $20 \%$ & $6 \mathrm{a}$ & $14 \%$ & 61 & $17 \%$ \\
\hline & 35 to 39 years & $28 a$ & $19 \%$ & $35 a$ & $22 \%$ & $11_{\mathrm{a}}$ & $25 \%$ & 74 & $21 \%$ \\
\hline & 40 to 49 years & $42 a$ & $29 \%$ & $31_{a}$ & $19 \%$ & $11 \mathrm{a}$ & $25 \%$ & 84 & $24 \%$ \\
\hline & 50 and up & $37 a$ & $25 \%$ & $17_{b}$ & $11 \%$ & $11_{\mathrm{a}}$ & $25 \%$ & 65 & $19 \%$ \\
\hline \multicolumn{2}{|c|}{ Total } & 146 & $100 \%$ & 159 & $100 \%$ & 44 & $100 \%$ & 349 & $100 \%$ \\
\hline
\end{tabular}

*Single men were not included in the analysis.

Note: Values in the same row and sub-table not sharing the same subscript are significantly different at $p<.05$ in the two-sided test of equality for column proportions. Cells with no subscript are not included in the test. Tests assume equal variances.

Tests are adjusted for all pairwise comparisons within a row of each innermost sub-table using the Bonferroni correction.

\footnotetext{
${ }^{3}$ Data from 353 respondents.

${ }^{4}$ In the majority of the tables presented in this report, no decimals will be used in order to facilitate reading. Due to this, in some cases, the sum of percentages might be higher than 100 , but this will not be stated on the table.
} 


\section{$2.2 \quad$ Ethnicity}

Regarding ethnicity, the majority of respondents are Goba (64\%), followed by Tonga (8\%) and Chikunda (7\%). No other ethnic groups in the sample are above 5\%. The results (see Table 2) do not show any statistically significant differences by gender/marital status. To test this further, men and women's ethnicity was compared (without taking into account their marital status) and the only statistically significant difference was found in being Chewa; $7 \%$ of men and $2 \%$ of women reported being Chewa, but as a group they are a minority in the sample.

Table 2. Ethnicity by gender/marital status

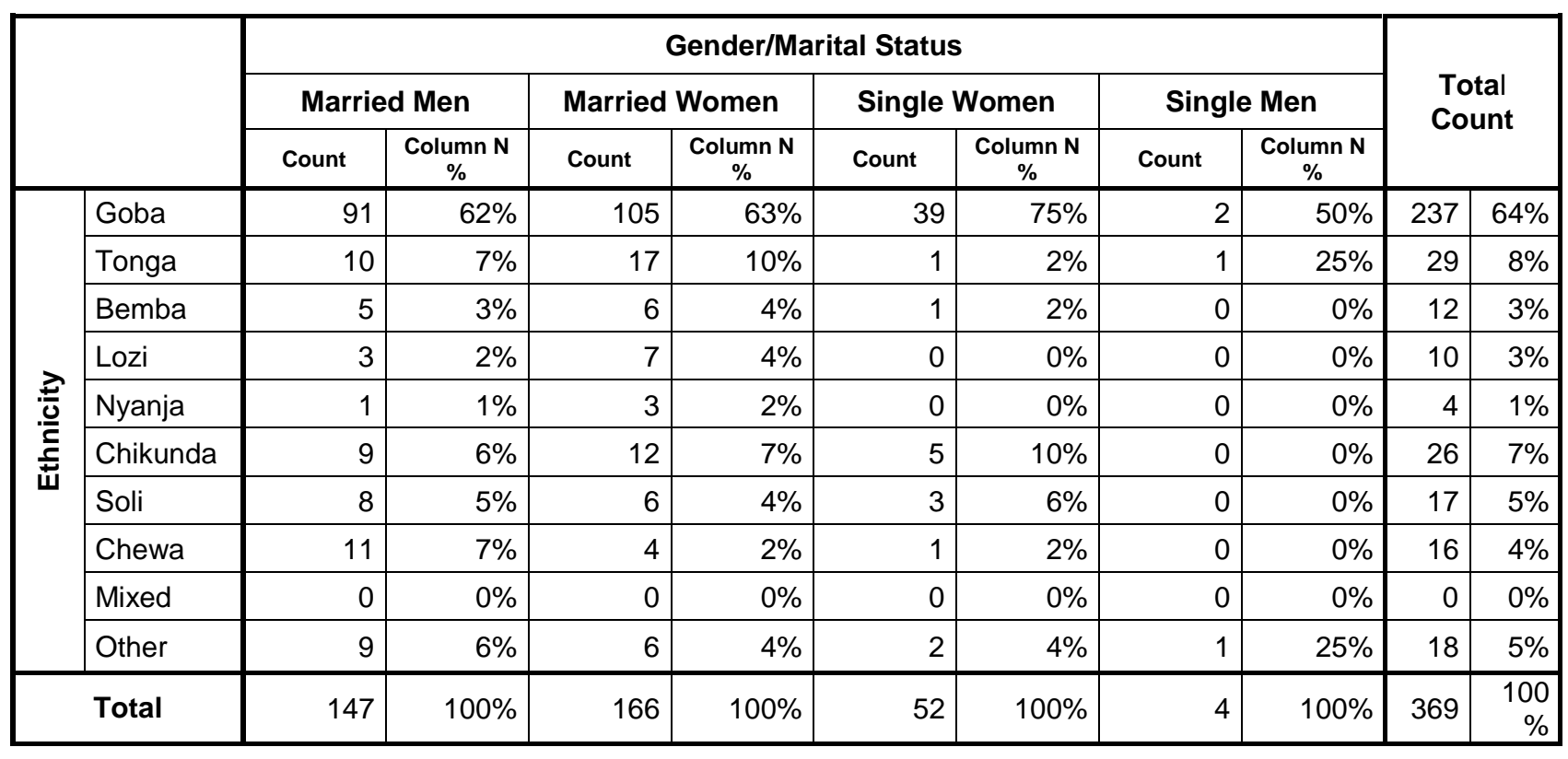




\section{3}

\section{Religion}

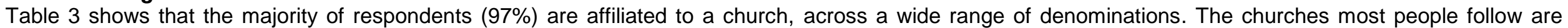

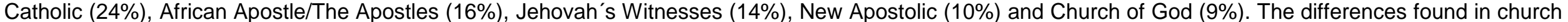

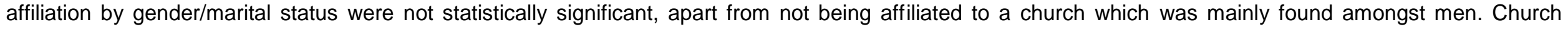

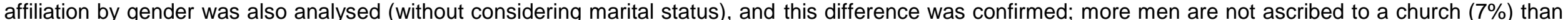
women (less than 1\%). It was also found that more women (6\%) were affiliated to the Assemblies of God church than men (2\%).

Table 3. Church affiliation by gender/marital status

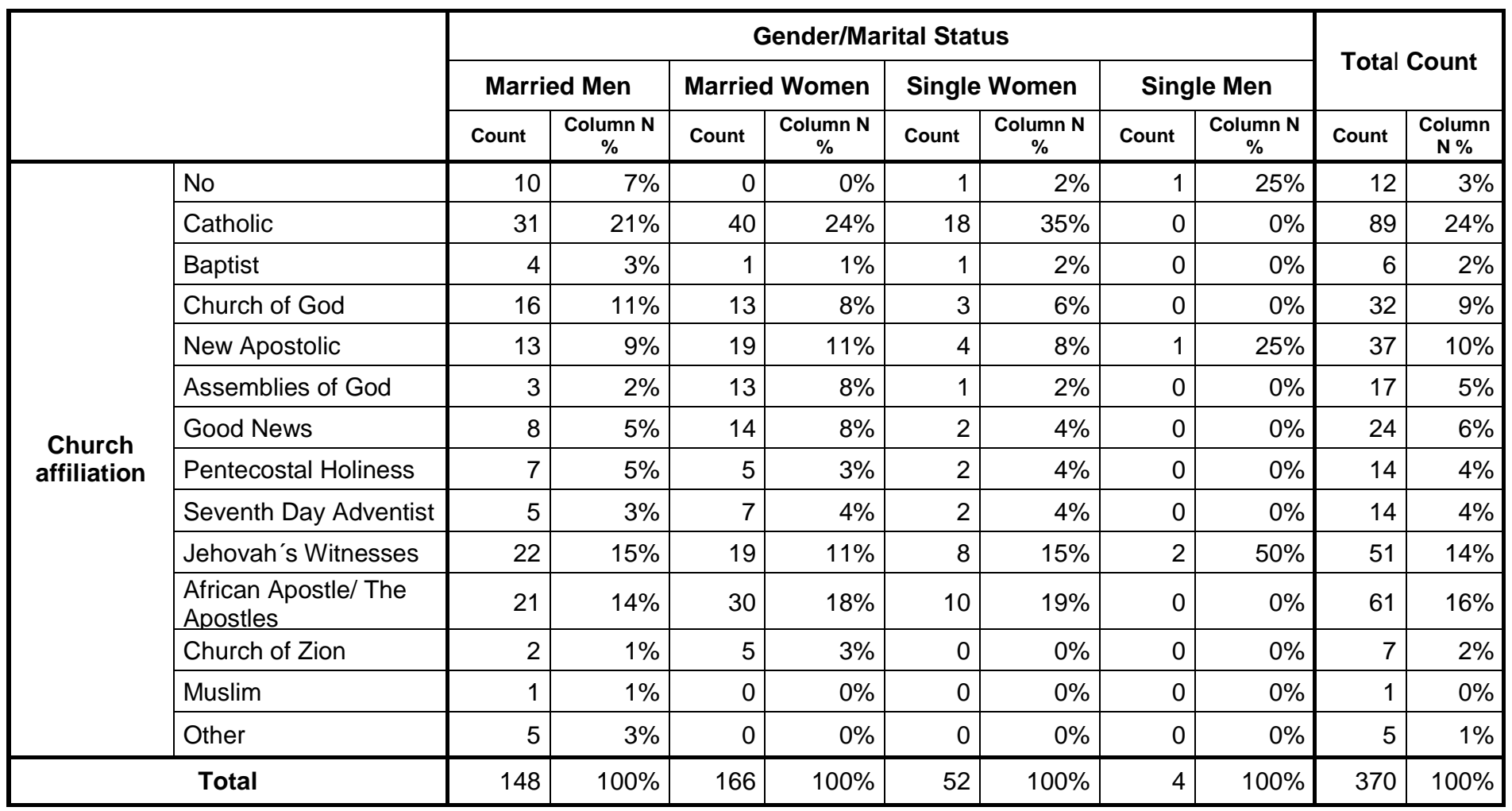


An analysis of ethnic group affiliation to different churches (Table 4) shows that the distribution follows the same pattern; the affiliation to a church among ethnic groups corresponds to the sample's most popular denominations. Very few statistically significant differences were found in different ethnic support of the most popular churches (probably due to the small count in some churches and ethnicities). The only significant finding is that Lozi and Soli groups are rarely Catholic, and that the Lozi ascribe more to New Apostolic and Seventh day Adventist than other ethnic groups. However, the amount of people in those ethnic groups is not very significant in the context of the whole sample.

Table 4. Church affiliation by ethnicity

\begin{tabular}{|c|c|c|c|c|c|c|c|c|c|c|c|c|c|c|c|c|c|c|c|}
\hline & & \multicolumn{16}{|c|}{ Ethnicity } & \multirow{2}{*}{\multicolumn{2}{|c|}{ Total Count }} \\
\hline & & \multicolumn{2}{|c|}{ Goba } & \multicolumn{2}{|c|}{ Tonga } & \multicolumn{2}{|c|}{ Bemba } & \multicolumn{2}{|c|}{ Lozi } & \multicolumn{2}{|c|}{ Chikunda } & \multicolumn{2}{|c|}{ Soli } & \multicolumn{2}{|c|}{ Chewa } & \multicolumn{2}{|c|}{ Other* } & & \\
\hline & & Count & $\begin{array}{c}\text { Column } \\
\mathbf{N} \% \\
\end{array}$ & Count & $\begin{array}{c}\text { Column } \\
\mathrm{N} \% \\
\end{array}$ & Count & $\begin{array}{c}\text { Column } \\
\mathrm{N} \% \\
\end{array}$ & Count & $\begin{array}{c}\text { Column } \\
\mathrm{N} \% \\
\end{array}$ & Count & \begin{tabular}{c|}
$\begin{array}{c}\text { Column } \\
\mathrm{N} \%\end{array}$ \\
\end{tabular} & Count & $\begin{array}{c}\text { Column } \\
\mathrm{N} \%\end{array}$ & Count & $\begin{array}{c}\text { Column } \\
\mathrm{N} \% \\
\end{array}$ & Count & $\begin{array}{c}\begin{array}{c}\text { Column } \\
\mathrm{N} \%\end{array} \\
\end{array}$ & & \\
\hline \multirow{14}{*}{ 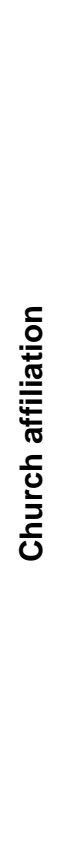 } & No & 7 & $3 \%$ & 2 & $7 \%$ & 0 & $0 \%$ & 0 & $0 \%$ & 1 & $4 \%$ & 0 & $0 \%$ & 1 & $6 \%$ & 1 & $5 \%$ & 12 & $3 \%$ \\
\hline & Catholic & 59 & $25 \%$ & 8 & $28 \%$ & 2 & $17 \%$ & 0 & $0 \%$ & 9 & $35 \%$ & 1 & $6 \%$ & 3 & $19 \%$ & 6 & $27 \%$ & 88 & $24 \%$ \\
\hline & Baptist & 2 & $1 \%$ & 0 & $0 \%$ & 0 & $0 \%$ & 0 & $0 \%$ & 0 & $0 \%$ & 0 & $0 \%$ & 3 & $19 \%$ & 1 & $5 \%$ & 6 & $2 \%$ \\
\hline & Church of God & 26 & $11 \%$ & 0 & $0 \%$ & 0 & $0 \%$ & 1 & $10 \%$ & 2 & $8 \%$ & 1 & $6 \%$ & 2 & $13 \%$ & 0 & $0 \%$ & 32 & $9 \%$ \\
\hline & New Apostolic & 24 & $10 \%$ & 4 & $14 \%$ & 2 & $17 \%$ & 4 & $40 \%$ & 0 & $0 \%$ & 0 & $0 \%$ & 0 & $0 \%$ & 3 & $14 \%$ & 37 & $10 \%$ \\
\hline & $\begin{array}{l}\text { Assemblies of } \\
\text { God }\end{array}$ & 9 & $4 \%$ & 2 & $7 \%$ & 1 & $8 \%$ & 1 & $10 \%$ & 0 & $0 \%$ & 1 & $6 \%$ & 1 & $6 \%$ & 2 & $9 \%$ & 17 & $5 \%$ \\
\hline & Good News & 13 & $5 \%$ & 1 & $3 \%$ & 3 & $25 \%$ & 0 & $0 \%$ & 1 & $4 \%$ & 2 & $12 \%$ & 1 & $6 \%$ & 3 & $14 \%$ & 24 & $7 \%$ \\
\hline & $\begin{array}{l}\text { Pentecostal } \\
\text { Holiness }\end{array}$ & 10 & $4 \%$ & 0 & $0 \%$ & 0 & $0 \%$ & 1 & $10 \%$ & 1 & $4 \%$ & 0 & $0 \%$ & 1 & $6 \%$ & 1 & $5 \%$ & 14 & $4 \%$ \\
\hline & $\begin{array}{l}\text { Seventh Day } \\
\text { Adventist }\end{array}$ & 5 & $2 \%$ & 1 & $3 \%$ & 1 & $8 \%$ & 2 & $20 \%$ & 0 & $0 \%$ & 2 & $12 \%$ & 2 & $13 \%$ & 1 & $5 \%$ & 14 & $4 \%$ \\
\hline & $\begin{array}{l}\text { Jehovah's } \\
\text { Witnesses }\end{array}$ & 39 & $16 \%$ & 2 & $7 \%$ & 0 & $0 \%$ & 0 & $0 \%$ & 4 & $15 \%$ & 4 & $24 \%$ & 1 & $6 \%$ & 1 & $5 \%$ & 51 & $14 \%$ \\
\hline & $\begin{array}{l}\text { Africa Apostle/ } \\
\text { The Apostles }\end{array}$ & 37 & $16 \%$ & 8 & $28 \%$ & 1 & $8 \%$ & 0 & $0 \%$ & 7 & $27 \%$ & 6 & $35 \%$ & 1 & $6 \%$ & 1 & $5 \%$ & 61 & $17 \%$ \\
\hline & Church of Zion & 4 & $2 \%$ & 1 & $3 \%$ & 0 & $0 \%$ & 0 & $0 \%$ & 1 & $4 \%$ & 0 & $0 \%$ & 0 & $0 \%$ & 1 & $5 \%$ & 7 & $2 \%$ \\
\hline & Muslim & 0 & $0 \%$ & 0 & $0 \%$ & 1 & $8 \%$ & 0 & $0 \%$ & 0 & $0 \%$ & 0 & $0 \%$ & 0 & $0 \%$ & 0 & $0 \%$ & 1 & $0 \%$ \\
\hline & Other & 2 & $1 \%$ & 0 & $0 \%$ & 1 & $8 \%$ & 1 & $10 \%$ & 0 & $0 \%$ & 0 & $0 \%$ & 0 & $0 \%$ & 1 & $5 \%$ & 5 & $1 \%$ \\
\hline & Total & 237 & $100 \%$ & 29 & $100 \%$ & 12 & $100 \%$ & 10 & $100 \%$ & 26 & $100 \%$ & 17 & $100 \%$ & 16 & $100 \%$ & 22 & $100 \%$ & 369 & $100 \%$ \\
\hline
\end{tabular}




\section{$2.4 \quad$ Marital status and marriage}

Table 5 shows that the majority of married men (74\%) and married women $(75 \%)$ are in their first marriage. Those who are in their second (or more) marriage were usually previously deserted/divorced ( $21 \%$ men and $22 \%$ women) while very few currently married people were previously widowed (5\% of men and $3 \%$ of women). The majority of single women are widows (55\%), with $39 \%$ deserted/divorced, and a very small number (only 2 women) has never been married. None of these differences were statistically significant, probably due to the fact that the groups are already divided by marital status and therefore already differentiated. These results were compared to the qualitative interviews and some under-reports of previous marriages were found in some cases. Some of the respondents (either currently married or not) did not mention in the survey previous marriages that had ended either in the death of the spouse, a divorce or desertion. As not all respondents were interviewed, we cannot give accurate figures on the extent of under-reporting, but suspect that the number of people who are in fact on their first marriage could be a little lower while the number of people previously widowed, or deserted/divorced and now re-married could be a little higher. We could speculate that one reason for this under-reporting could be that the marriage had not been formalised by the payment of bride-price even though the couple may have lived as though they were married. What is interesting in this table is that, amongst currently married people, there is no discernible difference by gender in the numbers of those who have previously been married.

Table 5. Marital status by gender/marital status

\begin{tabular}{|c|c|c|c|c|c|c|c|c|c|}
\hline & \multicolumn{6}{|c|}{ Gender/Marital Status* } & \multirow{3}{*}{\multicolumn{2}{|c|}{ Total }} \\
\hline & & \multicolumn{2}{|c|}{ Married Men } & \multicolumn{2}{|c|}{$\begin{array}{l}\text { Married } \\
\text { Women }\end{array}$} & \multicolumn{2}{|c|}{$\begin{array}{c}\text { Single } \\
\text { Women }\end{array}$} & & \\
\hline & & Count & \begin{tabular}{|c|} 
Column \\
$\mathrm{N} \%$
\end{tabular} & Count & $\begin{array}{c}\text { Column } \\
\mathrm{N} \%\end{array}$ & Count & $\begin{array}{c}\text { Column } \\
\mathbf{N} \%\end{array}$ & & \\
\hline \multirow{7}{*}{ Marital Status } & Single (never married) & 0 & $0 \%$ & 0 & $0 \%$ & 2 & $4 \%$ & 2 & $1 \%$ \\
\hline & Married (first marriage) & 110 & $74 \%$ & 124 & $75 \%$ & 0 & $0 \%$ & 234 & $64 \%$ \\
\hline & Separated & 0 & $0 \%$ & 0 & $0 \%$ & 1 & $2 \%$ & 1 & $0 \%$ \\
\hline & Widowed & 0 & $0 \%$ & 0 & $0 \%$ & 28 & $55 \%$ & 28 & $8 \%$ \\
\hline & Divorced/deserted & 0 & $0 \%$ & 0 & $0 \%$ & 20 & $39 \%$ & 20 & $5 \%$ \\
\hline & $\begin{array}{l}\text { Previously divorced/ } \\
\text { deserted now re-married }\end{array}$ & 31 & $21 \%$ & 37 & $22 \%$ & 0 & $0 \%$ & 68 & $19 \%$ \\
\hline & $\begin{array}{l}\text { Previously widowed now } \\
\text { re-married }\end{array}$ & 7 & $5 \%$ & 5 & $3 \%$ & 0 & $0 \%$ & 12 & $3 \%$ \\
\hline \multicolumn{2}{|r|}{ Total } & 148 & $100 \%$ & 166 & $100 \%$ & 51 & $100 \%$ & 365 & $100 \%$ \\
\hline
\end{tabular}

* The 4 currently single men (widowed and divorced) were excluded from this table.

Note: No significant differences were found between gender/marital status groups.

The average number of years that respondents have been in their current marital state is 15 , although married men stated a slightly higher average (17) than married women (15). By contrast, single women have been in their current marital state for an average of 9 years.

In the following table (Table 6$)$, it can be seen that 92 respondents $(24.1 \%$ of the total sample) have had at least one marriage that ended in desertion or divorce, and most of these $(73,19.7 \%$ of the total sample) have had only one previous marriage. Only 15 people (4 married men, 6 married women and 5 single women) have had 2 marriages that ended in desertion/divorce, and only one respondent (a married man) has had 3 marriages that ended in desertion/divorce. As was mentioned before, respondents may have under-reported previous marriages in the survey, and so these results should be taken with caution - the number of people with either one or two marriages that ended in desertion/divorce could be higher. 
Table 6. Number of marriages that ended in desertion/divorce by gender/marital status

\begin{tabular}{|c|c|c|c|c|c|c|c|c|c|}
\hline & & \multicolumn{6}{|c|}{ Gender/Marital Status* } & \multirow{3}{*}{\multicolumn{2}{|c|}{ Total }} \\
\hline & & \multicolumn{2}{|c|}{ Married Men } & \multicolumn{2}{|c|}{ Married Women } & \multicolumn{2}{|c|}{ Single Women } & & \\
\hline & & Count & $\begin{array}{c}\begin{array}{c}\text { Percent } \\
\text { (total } \\
\text { sample) }\end{array} \\
\end{array}$ & Count & $\begin{array}{c}\text { Percent } \\
\text { (total } \\
\text { sample) } \\
\end{array}$ & Count & $\begin{array}{l}\text { Percent } \\
\text { (total } \\
\text { sample) } \\
\end{array}$ & & \\
\hline \multirow{3}{*}{$\begin{array}{l}\text { No. marriages } \\
\text { that ended in } \\
\text { desertion/ } \\
\text { divorce }\end{array}$} & 1 & 29 & $7.8 \%$ & 29 & $7.8 \%$ & 15 & $4.1 \%$ & 73 & $19.7 \%$ \\
\hline & 2 & 4 & $1.1 \%$ & 6 & $1.6 \%$ & 5 & $1.4 \%$ & 15 & $4.1 \%$ \\
\hline & 3 & 1 & $0.3 \%$ & 0 & $0.0 \%$ & 0 & $0.0 \%$ & 1 & $0.3 \%$ \\
\hline \multicolumn{2}{|l|}{ Total } & 34 & $9 \%$ & 35 & $9 \%$ & 20 & $5 \%$ & 89 & $24.1 \%$ \\
\hline
\end{tabular}

${ }^{*} 3$ single men that are divorced are not included in the table.

${ }^{* *}$ The percentages were calculated for the whole sample and not just for married men in order to get a better depiction of marriages that ended in desertion divorce in general.

The number of marriages that have ended in death was 3\% on average for married men, $2 \%$ for married women and $8 \%$ for single women (with statistically significant differences between single women and the rest). Table 7 presents the disaggregated numbers; in total 46 respondents $(13 \%$ of the total sample) have had at least one marriage ending in death. 30 of these ( $8 \%$ of the total sample) are single women (more than half the total number of single women in the sample), while only 11 are married men and 7 married women. The same caution needs to be exercised with these results due to potential under-reporting of marriages ending in death.

Table 7. Number of marriages that ended in death by gender/marital status

\begin{tabular}{|c|c|c|c|c|c|c|c|c|c|}
\hline & & \multicolumn{6}{|c|}{ Gender/Marital Status* } & \multirow{3}{*}{\multicolumn{2}{|c|}{ Total }} \\
\hline & & \multicolumn{2}{|c|}{ Married Men } & \multicolumn{2}{|c|}{ Married Women } & \multicolumn{2}{|c|}{ Single Women } & & \\
\hline & & Count & $\begin{array}{c}\text { Percent } \\
\text { (total } \\
\text { sample) } \\
\end{array}$ & Count & $\begin{array}{c}\text { Percent } \\
\text { (total } \\
\text { sample) } \\
\end{array}$ & Count & $\begin{array}{c}\text { Percent } \\
\text { (total } \\
\text { sample) } \\
\end{array}$ & & \\
\hline \multirow{2}{*}{$\begin{array}{c}\text { \# of marriages } \\
\text { that ended in } \\
\text { death }\end{array}$} & 1 & 11 & $3.0 \%$ & 6 & $1.6 \%$ & 29 & $7.8 \%$ & 46 & $12.4 \%$ \\
\hline & 2 & 0 & $0.0 \%$ & 1 & $0.3 \%$ & 1 & $0.3 \%$ & 2 & $0.5 \%$ \\
\hline \multicolumn{2}{|l|}{ Total } & 11 & $3 \%$ & 7 & $2 \%$ & 30 & $8 \%$ & 46 & $13 \%$ \\
\hline
\end{tabular}

* 1 single widowed man is not included in the table.

${ }^{* *}$ The percentages were calculated for the whole sample and not just for married men in order to get a better picture of marriages that ended in desertion/divorce in general.

\section{Household composition}

\subsection{Household members living at home}

When we had data from both spouses, the data from the household head was kept and the spouse's was set aside to avoid double counting household members. The household head's data was selected as the question on household composition asked about the relationship of each household member to the household head and would therefore yield more consistent data. For this section the responses come from 148 married men, 25 married women, 4 single men and 52 single women, of whom $87 \%$ are household heads, $8 \%$ are spouses, $3 \%$ sons or daughters of household heads and the rest (less than $2 \%)$ are either grandchildren, siblings or other.

It is important to mention that when comparing answers from husbands and wives some inconsistencies in the reported age and educational level of household members were noted. In some cases inconsistencies in occupation and even in the number of household members were found. Furthermore there are several missing values in age, education or occupation - due to this, totals may vary from one table to another. 
Most households are either extended (53\%) or nuclear $(43 \%)$ with very few grandparent and subnuclear households (together less than $4 \%$ ) and only 1 joint household. The average number of people in households is 6.5. For both married men and married women, the average is slightly higher at 6.8, and is statistically significantly different from the single women average household mean which is 5.2 . Single women households are therefore smaller than those of married people.

Households were also grouped according to the number of people belonging to them (Table 8 ): $27 \%$ of households have between 1 and 4 members, 44\% between 5 and 7,25\% between 8 and 10 and only $5 \%$ between 11 and 14 .

Table 8. Number of people in the household

\begin{tabular}{|l|r|r|}
\hline \multicolumn{2}{|c|}{ Number of people in the household } \\
\hline & Count & Percentage \\
\hline 1 to 4 & 62 & $27 \%$ \\
\hline 5 to 7 & 100 & $44 \%$ \\
\hline 8 to 10 & 56 & $25 \%$ \\
\hline 11 to 14 & 11 & $5 \%$ \\
\hline \multicolumn{1}{|c|}{ Total } & 229 & $100 \%$ \\
\hline
\end{tabular}

Of the total household members, the majority (47.6\%) are either sons or daughters from the household head, $16.2 \%$ are household heads, $12 \%$ are spouses, $8.6 \%$ are their grandchildren, $6.6 \%$ their nephews or nieces and $2.9 \%$ step-sons or step-daughters. The remaining are cousins, grandparents, non-kin children, siblings and siblings-in law, parents and parents in-law or other (Table 9).

Table 9. Number of people in the household

\begin{tabular}{|c|c|c|c|c|c|c|}
\hline & \multicolumn{4}{|c|}{ Member relation to household head } & \multirow{2}{*}{\multicolumn{2}{|c|}{ Total }} \\
\hline & \multicolumn{2}{|c|}{ Female } & \multicolumn{2}{|c|}{ Male } & & \\
\hline & Count & Column N \% & Count & Column N \% & Count & Column N \% \\
\hline Household head & 57 & $7.9 \%$ & 175 & $24.6 \%$ & 232 & $16.2 \%$ \\
\hline Spouse & 171 & $23.6 \%$ & 1 & $0.1 \%$ & 172 & $12.0 \%$ \\
\hline Son/daughter & 329 & $45.3 \%$ & 356 & $50.1 \%$ & 685 & $47.7 \%$ \\
\hline Step-son/step-daughter & 22 & $3.0 \%$ & 20 & $2.8 \%$ & 42 & $2.9 \%$ \\
\hline Parent & 10 & $1.4 \%$ & 3 & $0.4 \%$ & 13 & $0.9 \%$ \\
\hline Parent-in-law & 2 & $0.3 \%$ & 0 & $0.0 \%$ & 2 & $0.1 \%$ \\
\hline Grandchild & 70 & $9.6 \%$ & 53 & $7.5 \%$ & 123 & $8.6 \%$ \\
\hline Sibling & 9 & $1.2 \%$ & 15 & $2.1 \%$ & 24 & $1.7 \%$ \\
\hline Sibling-in-law & 12 & $1.7 \%$ & 15 & $2.1 \%$ & 27 & $1.9 \%$ \\
\hline Nephew/niece & 32 & $4.4 \%$ & 64 & $9.0 \%$ & 96 & $6.7 \%$ \\
\hline Grandparent & 3 & $0.4 \%$ & 0 & $0.0 \%$ & 3 & $0.2 \%$ \\
\hline Cousin & 2 & $0.3 \%$ & 1 & $0.1 \%$ & 3 & $0.2 \%$ \\
\hline Non-kin child & 5 & $0.7 \%$ & 4 & $0.6 \%$ & 9 & $0.6 \%$ \\
\hline Other & 2 & $0.3 \%$ & 3 & $0.4 \%$ & 5 & $0.3 \%$ \\
\hline Total & 726 & $100 \%$ & 710 & $100 \%$ & 1436 & $100 \%$ \\
\hline
\end{tabular}

Notes: The results reflect the addition of all the household members plus the respondent's relationship to the household head. 5 cases had no gender information and thus are not included in this table. 
Due to the inconsistences in the data and responses, the analysis in this section does not assess statistically significant differences.

Most household members (787 people, or $54.6 \%$ of all household members ${ }^{5}$ ) are under $19 .^{6}$ The following table (Table 10) shows that the majority of children are the sons or daughters of the household head $(71 \%)$, some are their grandchildren (13\%) and some nephews/nieces (8\%).

Table 10. Member's relation to household head by age groups (below 19 years old)

\begin{tabular}{|c|c|c|c|c|c|c|c|c|c|c|c|}
\hline & \multicolumn{8}{|c|}{ Members under 19 (age groups) } & \multirow{2}{*}{\multicolumn{2}{|c|}{ Total }} \\
\hline & & \multicolumn{2}{|c|}{0 to 6 years } & \multicolumn{2}{|c|}{7 to 13 years } & \multicolumn{2}{|c|}{14 to 16 years } & \multicolumn{2}{|c|}{17 to 19 years } & & \\
\hline & & Count & $\begin{array}{c}\text { Column } \\
\mathrm{N} \%\end{array}$ & Count & $\begin{array}{c}\text { Column } \\
\mathrm{N} \%\end{array}$ & Count & $\begin{array}{c}\text { Column } \\
\mathrm{N} \%\end{array}$ & Count & $\begin{array}{c}\text { Column } \\
\mathrm{N} \%\end{array}$ & Count & $\begin{array}{c}\text { Column } \\
\mathrm{N} \%\end{array}$ \\
\hline \multirow{10}{*}{ 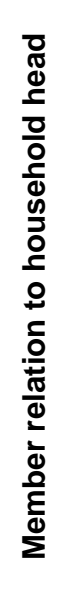 } & Spouse & 0 & $0 \%$ & 0 & $0 \%$ & 0 & $0 \%$ & 4 & 45 & 4 & $1 \%$ \\
\hline & Son/daughter & 204 & $74 \%$ & 224 & $77 \%$ & 73 & $61 \%$ & 57 & $60 \%$ & 558 & $71 \%$ \\
\hline & $\begin{array}{l}\text { Step- } \\
\text { son/step- } \\
\text { daughter }\end{array}$ & 3 & $1 \%$ & 13 & $4 \%$ & 7 & $6 \%$ & 5 & $5 \%$ & 28 & $4 \%$ \\
\hline & Grandchild & 56 & $20 \%$ & 28 & $10 \%$ & 10 & $8 \%$ & 6 & $6 \%$ & 100 & $13 \%$ \\
\hline & Sibling & 0 & $0 \%$ & 3 & $1 \%$ & 1 & $1 \%$ & 5 & $5 \%$ & 9 & $1 \%$ \\
\hline & Sibling-in-law & 1 & $0 \%$ & 3 & $1 \%$ & 6 & $5 \%$ & 2 & $2 \%$ & 12 & $2 \%$ \\
\hline & Nephew/niece & 13 & $5 \%$ & 16 & $6 \%$ & 21 & $18 \%$ & 14 & $15 \%$ & 64 & $8 \%$ \\
\hline & Cousin & 0 & $0 \%$ & 0 & $0 \%$ & 1 & $1 \%$ & 0 & $0 \%$ & 1 & $0 \%$ \\
\hline & Non-kin child & 0 & $0 \%$ & 2 & $1 \%$ & 1 & $1 \%$ & 2 & $2 \%$ & 5 & $1 \%$ \\
\hline & Other & 0 & $0 \%$ & 1 & $0 \%$ & 0 & $0 \%$ & 0 & $0 \%$ & 1 & $0 \%$ \\
\hline & Total & 288 & $100 \%$ & 307 & $100 \%$ & 126 & $100 \%$ & 96 & $100 \%$ & 817 & $100 \%$ \\
\hline
\end{tabular}

Note: There is no data regarding the relationship to the household head of 5 people under 19 years old.

The occupation of household members was examined in two groups, those aged 0 to 19 years old and those 20 years and older. ${ }^{7}$ The majority of household members younger than 19 are students (66\%) or have no occupation (30\%, but most of these are below 6 years old). Household members aged 20 or above are mainly housewives $(20 \%)$, unemployed $(12 \%)$, farmers $(19 \%)$, safari lodge workers $(11 \%)$, students $(7 \%)$, pieceworkers $(6 \%)$, petty traders $(5 \%)$, have a private job $(3 \%)$, commercial farm workers $(2 \%)$ teachers $(2 \%)$, or have no occupation $(2 \%)$. None of the other occupations constitutes more than $1 \%$ of the sample.

\subsection{Household members living away}

Of the 229 households, 92 say that they have at least one household member who is currently not living at home. However, when comparing husbands' and wives' answers it was found that 41 of these households do not have the same answers and either the husband (15) or wife (26) do not report that there is a household member living away. Given this, all the cases, where either husband or wife said that a household member is living away, were analysed and are reported here. To avoid duplicates, when both spouses said there was a household member living away the responses were compared; if they were reporting the same individual, then the household head's answer was kept and the spouse's set aside. If the answers did not match, then both were kept as they were understood to be referring to different people. As mentioned in the previous section, there are several missing values in age, education or occupation and, due to this, totals may vary between tables.

\footnotetext{
${ }^{5}$ There is no data on age for 156 household members.

${ }^{6}$ The age of 19 was used because that is the age at which upper secondary education should finish.

7156 household members are not included in these percentages due to a lack of data on age or occupation. Percentages are given on the total number of household members for which we had complete data (1283).
} 
In total, there are 152 household members living away (46 females and 106 males). On average, households have 1.7 members living somewhere else. In Table 14 the relationship to the household head of the member living away is differentiated by gender. This table only includes those households which have members living away, to enable easier analysis of gender differences. The household members that are away are mostly sons or daughters, who together constitute $53 \%$ of the members living away. Furthermore, it can be seen that within this number there are more sons $(36 \%$ of all members living away) than daughters (17\% of all members living away). $20 \%$ of those living away are household heads, and the majority of these are male $(19 \%$ of all members living away are male household heads). In general, $70 \%$ of the members living away are males. However, when probing the data further, the gender difference is not present for children under 19. Of the 63 children under 19 living away, 35 are female and 28 male. The gender difference therefore appears to be due to household heads and other males living away for work, not for education. The fact that more sons are working away may reflect the fact that girls tend to marry younger so are more likely to be living in their own marital household past schooling age.

Table 11. Household members living away relation to household head away by gender

\begin{tabular}{|c|c|c|c|c|c|c|c|}
\hline & & \multicolumn{4}{|c|}{ Gender } & \multirow{2}{*}{\multicolumn{2}{|c|}{ Total }} \\
\hline & & \multicolumn{2}{|c|}{ Female } & \multicolumn{2}{|c|}{ Male } & & \\
\hline & & Count & $\begin{array}{c}\text { Table N } \\
\%\end{array}$ & Count & $\begin{array}{c}\text { Table N } \\
\%\end{array}$ & Count & $\begin{array}{c}\text { Table N } \\
\%\end{array}$ \\
\hline \multirow{8}{*}{$\begin{array}{l}\text { Household } \\
\text { member } \\
\text { living away: } \\
\text { Relation to } \\
\text { Household } \\
\text { head }\end{array}$} & Household head & 2 & $1 \%$ & 29 & $19 \%$ & 31 & $20 \%$ \\
\hline & Spouse & 1 & $1 \%$ & 0 & $0 \%$ & 1 & $1 \%$ \\
\hline & Son/daughter & 26 & $17 \%$ & 54 & $36 \%$ & 80 & $53 \%$ \\
\hline & \begin{tabular}{|l|} 
Step-son/ \\
step-daughter
\end{tabular} & 7 & $5 \%$ & 1 & $1 \%$ & 8 & $5 \%$ \\
\hline & Grandchild & 3 & $2 \%$ & 5 & $3 \%$ & 8 & $5 \%$ \\
\hline & Sibling & 3 & $2 \%$ & 3 & $2 \%$ & 6 & $4 \%$ \\
\hline & Sibling-in-law & 2 & $1 \%$ & 5 & $3 \%$ & 7 & $5 \%$ \\
\hline & Nephew/niece & 2 & $1 \%$ & 9 & $6 \%$ & 11 & $7 \%$ \\
\hline \multicolumn{2}{|r|}{ Total } & 46 & $30 \%$ & 106 & $70 \%$ & 152 & $100 \%$ \\
\hline
\end{tabular}

Additionally, the majority of members living away are students (46\%), followed by safari lodge workers (34\%). Some are unemployed (7\%), a few are pieceworkers (5\%). None of the rest of the occupations account for more than $2 \%$ of the living away sample. Regarding their residence, and consistent with their occupation, $37 \%$ of household members that live away are away for work for part of the year; $21 \%$ are boarding at school, $17 \%$ are living with kin and $16 \%$ staying with kin for education during term time (table with these totals not shown). In Table 12 the results are presented differently to other tables to highlight the gender differences; instead of column percentages and totals, row percentages and totals by gender are used. No women are away for work all year, and only $4 \%$ of household members who work away from home for part of the year are women. However, there is no real difference in the number of male and female students studying away from home, whether at school boarding facilities or staying with kin nearer to a school. 
Table 12. Household members living away: place of residence by gender

\begin{tabular}{|c|c|c|c|c|c|c|c|}
\hline & & \multicolumn{4}{|c|}{ Gender } & \multirow{2}{*}{\multicolumn{2}{|c|}{ Total }} \\
\hline & & \multicolumn{2}{|c|}{ Female } & \multicolumn{2}{|c|}{ Male } & & \\
\hline & & Count & Row N \% & Count & Row N \% & Count & Row N \% \\
\hline \multirow{7}{*}{$\begin{array}{l}\text { Household } \\
\text { member living } \\
\text { away: Place of } \\
\text { residence }\end{array}$} & Away for work all year & 0 & $0 \%$ & 6 & $100 \%$ & 6 & $100 \%$ \\
\hline & Away for work part of year & 4 & $7 \%$ & 52 & $93 \%$ & 56 & $100 \%$ \\
\hline & Boarding at school & 16 & $50 \%$ & 16 & $50 \%$ & 32 & $100 \%$ \\
\hline & Living with kin & 10 & $38 \%$ & 16 & $62 \%$ & 26 & $100 \%$ \\
\hline & $\begin{array}{l}\text { Staying with kin for } \\
\text { education-away all year }\end{array}$ & 3 & $75 \%$ & 1 & $25 \%$ & 4 & $100 \%$ \\
\hline & $\begin{array}{l}\text { Staying with kin for } \\
\text { education-term time only }\end{array}$ & 12 & $48 \%$ & 13 & $52 \%$ & 25 & $100 \%$ \\
\hline & Other* & 1 & $33 \%$ & 2 & $67 \%$ & 3 & $100 \%$ \\
\hline \multicolumn{2}{|r|}{ Total } & 46 & $30 \%$ & 106 & $70 \%$ & 152 & $100 \%$ \\
\hline
\end{tabular}

* Other includes living with other parent and staying with non-kin for education -away all year.

\subsection{Sons and daughters of the household head or spouse who no longer live in the household}

Of the 229 households in the sample, 130 say that they have sons or daughters no longer living at home. As in the previous section, some households (26 in this case) don't agree on the number of sons or daughters no longer living at home (19 wives and 7 husbands say that there are no sons or daughters living away while their spouses say there are). This could be because husbands and wives are reporting about children from other relationships. Due to this, and to avoid duplicates, all the cases in which there was only data from either the husband or the wife were kept. When both said they had sons or daughters living away their answers were compared; when they were referring to the same person (exact match in data) the household's head report was kept and the spouse's set aside. If the data did not match both answers were kept. Additionally, we found a lot of missing values in the members' education and/ or age and due to this, totals may vary from one table another.

There are 414 sons or daughters no longer living at home; within this number there are more girls (246) than boys (167) not living at home. Most of the children not at home are the sons or daughters of the household head (92\%) and 5\% are step sons or daughters. The majority of children not living at home are over 17 (74\%) and that is true for both male and female.

Most of these sons and daughters are living in their own household (70\%) or living with kin (19\%) (Results are not shown in tables). In Table 34 the residence of the household members not living at home can be seen differentiated by gender. As in the previous table, instead of having column percentages and totals, row percentages and totals by gender are used. The most noteworthy gender differences can be seen in those living in their own household; more females $(62 \%$ of the total of members that have their own household), than males (38\%) are living in their own household. More daughters $(63 \%)$ than sons (37\%) are living with their other parent. 
Table 13. Sons or daughters not living at home: residence by gender

\begin{tabular}{|c|c|c|c|c|c|c|c|}
\hline & \multicolumn{4}{|c|}{$\begin{array}{c}\text { Gender } \\
\text { (of household member) }\end{array}$} & \multirow{2}{*}{\multicolumn{2}{|c|}{ Total }} \\
\hline & & \multicolumn{2}{|c|}{ Female } & \multicolumn{2}{|c|}{ Male } & & \\
\hline & & Count & Row N \% & Count & Row N \% & Count & Row N \% \\
\hline \multirow{8}{*}{$\begin{array}{c}\text { Sons or } \\
\text { daughters no } \\
\text { longer living at } \\
\text { home: } \\
\text { Residence }\end{array}$} & $\begin{array}{l}\text { Away for work part of } \\
\text { year }\end{array}$ & 0 & $0 \%$ & 2 & $100 \%$ & 2 & $100 \%$ \\
\hline & Boarding at school & 2 & $67 \%$ & 1 & $33 \%$ & 3 & $100 \%$ \\
\hline & Living in own household & 170 & $62 \%$ & 103 & $38 \%$ & 273 & $100 \%$ \\
\hline & Living with kin & 42 & $56 \%$ & 33 & $44 \%$ & 75 & $100 \%$ \\
\hline & Living with other parent & 12 & $63 \%$ & 7 & $37 \%$ & 19 & $100 \%$ \\
\hline & $\begin{array}{l}\text { Staying with kin for } \\
\text { education-away all year }\end{array}$ & 7 & $50 \%$ & 7 & $50 \%$ & 14 & $100 \%$ \\
\hline & $\begin{array}{l}\text { Staying with kin for } \\
\text { education-term time only }\end{array}$ & 1 & $33 \%$ & 3 & $67 \%$ & 4 & $100 \%$ \\
\hline & Other & 2 & $100 \%$ & 0 & $0 \%$ & 2 & $100 \%$ \\
\hline \multicolumn{2}{|r|}{ Total } & 234 & $60 \%$ & 156 & $40 \%$ & 390 & $100 \%$ \\
\hline
\end{tabular}

\section{Education}

The school system in Zambia consists of 7 years of primary, 2 years in lower secondary (grades 8 and 9 ) and 3 years of upper secondary (grades 10 to 12).

\subsection{Respondents' education}

Attainment levels are low in general; only $9 \%$ have reached (but not necessarily finished) upper secondary, $16 \%$ have reached lower secondary, and the majority $(57 \%)$ only reached primary. It is also important to draw attention to the fact that more men have reached higher levels of education than women. When comparing school level with gender marital status (Table 14) almost all comparisons are statistically significant when comparing married men to single and married women (and no significant difference arises between women by marital status). Due to this, gender differences (without marital status) were also explored and the results are shown in Table 15. In this table, it is noteworthy that only $5 \%$ of men have no education while the percentage for women is $22 \%$. Additionally, $62 \%$ of women have only reached primary level. This percentage is lower for men (49\%) as they have progressed to higher educational levels; $18 \%$ of men have reached upper secondary, while for women the percentage is only $4 \%$. 


\begin{tabular}{|c|c|c|c|c|c|c|c|c|c|}
\hline & & \multicolumn{6}{|c|}{ Gender/Marital Status } & \multirow{2}{*}{\multicolumn{2}{|c|}{ Total }} \\
\hline & & \multicolumn{2}{|c|}{ Married Men } & \multicolumn{2}{|c|}{ Married Women } & \multicolumn{2}{|c|}{ Single Women } & & \\
\hline & & Count & $\begin{array}{c}\text { Column } \\
\mathbf{N} \%\end{array}$ & Count & $\begin{array}{c}\text { Column N } \\
\%\end{array}$ & Count & $\begin{array}{c}\text { Column N } \\
\%\end{array}$ & & \\
\hline \multirow{5}{*}{$\begin{array}{l}\text { School level } \\
\text { reached }^{\star}\end{array}$} & None & $6 a$ & $4 \%$ & $32 b$ & $19 \%$ & $15 b$ & $29 \%$ & 53 & $14 \%$ \\
\hline & $\begin{array}{l}\text { Some Primary } \\
\text { (Kinder-7) }\end{array}$ & $74 a$ & $50 \%$ & $103_{a}$ & $62 \%$ & $33 a$ & $64 \%$ & 210 & $57 \%$ \\
\hline & $\begin{array}{l}\text { Some Lower } \\
\text { Secondary (8-9) }\end{array}$ & $34 a$ & $23 \%$ & $22_{a, b}$ & $13 \%$ & $2 b$ & $4 \%$ & 58 & $16 \%$ \\
\hline & $\begin{array}{l}\text { Some Upper } \\
\text { Secondary (10-12) }\end{array}$ & $26 a$ & $18 \%$ & $6 b$ & $4 \%$ & $2 b$ & $4 \%$ & 34 & $9 \%$ \\
\hline & Tertiary education & $8 a$ & $5 \%$ & $3 a$ & $2 \%$ & $0^{1}$ & $0 \%$ & 11 & $3 \%$ \\
\hline \multicolumn{2}{|c|}{ Total } & 148 & $100 \%$ & 166 & $100 \%$ & 52 & $100 \%$ & 366 & $100 \%$ \\
\hline
\end{tabular}

* School level reached and not necessarily passed

Note: Values in the same row and sub-table not sharing the same subscript are significantly different at $p<.05$ in the twosided test of equality for column proportions. Cells with no subscript are not included in the test. Tests assume equal variances. $^{2}$

1. This category is not used in comparisons because its column proportion is equal to zero or one.

2. Tests are adjusted for all pairwise comparisons within a row of each innermost sub-table using the Bonferroni correction.

Table 15. School level reached by gender

\begin{tabular}{|c|c|c|c|c|c|c|c|}
\hline & & \multicolumn{4}{|c|}{ Gender } & \multirow{2}{*}{\multicolumn{2}{|c|}{ Total }} \\
\hline & & \multicolumn{2}{|c|}{ Male } & \multicolumn{2}{|c|}{ Female } & & \\
\hline & & Count & Column \% & Count & Column \% & & \\
\hline \multirow{5}{*}{$\begin{array}{l}\text { School level } \\
\text { reached }\end{array}$} & None & $7 \mathrm{a}$ & $5 \%$ & $47 \mathrm{~b}$ & $22 \%$ & 54 & $15 \%$ \\
\hline & Some Primary (Kinder-7) & $74 a$ & $49 \%$ & $136 b$ & $62 \%$ & 210 & $57 \%$ \\
\hline & $\begin{array}{l}\text { Some Lower Secondary (8- } \\
\text { 9) }\end{array}$ & $35 a$ & $23 \%$ & $24 b$ & $11 \%$ & 59 & $16 \%$ \\
\hline & $\begin{array}{l}\text { Some Upper Secondary (10- } \\
12)\end{array}$ & $28 a$ & $18 \%$ & $8 b$ & $4 \%$ & 36 & $10 \%$ \\
\hline & Tertiary education & $8 a$ & $5 \%$ & $3 b$ & $1 \%$ & 11 & $3 \%$ \\
\hline \multicolumn{2}{|r|}{ Total } & 152 & $100 \%$ & 218 & $100 \%$ & 370 & $100 \%$ \\
\hline
\end{tabular}

Note: Values in the same row and sub-table not sharing the same subscript are significantly different at $\mathrm{p}<.05$ in the two-sided test of equality for column proportions. Cells with no subscript are not included in the test. Tests assume equal variances. Tests are adjusted for all pairwise comparisons within a row of each innermost sub-table using the Bonferroni correction. 
Overall $24.9 \%$ of household members have no education, $50.6 \%$ have reached primary, $16 \%$ lower secondary, $9.2 \%$ upper secondary and only $0.4 \%$ tertiary education. Given the high percentage of children under 19, it is important to present a more detailed account by dividing between age groups. The majority of children under 6 are not yet in education (76\%) and $23 \%$ are attending kindergarten or primary. In the 7 to 13 age group that corresponds to the ages for attending primary, and in which it would be expected that all should be attending education, only $4 \%$ have no schooling and the vast majority (94\%) are attending primary. In the 14 to 16 age group (corresponding to lower secondary) none have no schooling; $57 \%$ have reached primary, $39 \%$ have reached lower secondary, and $4 \%$ upper secondary. In the 17 to 19 age group (corresponding to the appropriate age for upper secondary), $3 \%$ have no schooling, $24 \%$ have reached primary, $47 \%$ lower secondary and $25 \%$ upper secondary. In the higher age groups, a shift can be seen, i.e. the older the age group the lower the percentage of people that have reached higher levels of education and the higher the percentage of people that are not educated. In the 30 and over age bracket, more than $68 \%$ of people in every age group have either no education or have only reached primary. Two conclusions are therefore clear; younger generations are increasingly attending school, but nonetheless children are not progressing to the educational levels that correspond to their age.

Table 16. Household members' educational level by age

\begin{tabular}{|c|c|c|c|c|c|c|c|c|c|c|c|c|c|c|c|c|c|c|c|c|c|}
\hline & & \multicolumn{18}{|c|}{ Age groups (of household member) } & \multicolumn{2}{|c|}{ Total } \\
\hline & & \multicolumn{2}{|c|}{0 to 6 years } & \multicolumn{2}{|c|}{7 to 13 years } & \multicolumn{2}{|c|}{14 to 16 years } & \multicolumn{2}{|c|}{17 to 19 years } & \multicolumn{2}{|c|}{20 to 29 years } & \multicolumn{2}{|c|}{30 to 34 years } & \multicolumn{2}{|c|}{35 to 39 years } & \multicolumn{2}{|c|}{40 to 49 years } & \multicolumn{2}{|c|}{50 and up } & & \\
\hline & & ت̃ & $\begin{array}{l}z \\
\text { ह⿱宀 } \\
\text { jo }_{0}^{\circ}\end{array}$ & క్ & 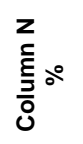 & $\overline{\mathrm{s}}$ & 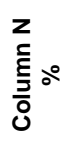 & క్ & $\begin{array}{l}z \\
\text { हᄐ } \\
\underbrace{\circ}_{0}\end{array}$ & క్ & 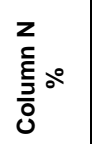 & క్ & z & క్ & 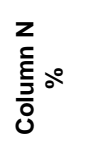 & $\overrightarrow{\mathrm{s}}$ & 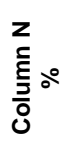 & 志 & 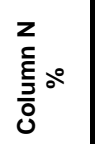 & ț & $\begin{array}{l}z \\
\text { E⿱ } \\
\text { కㅇㅇㅇ }\end{array}$ \\
\hline \multirow{5}{*}{ 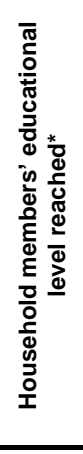 } & None & 215 & $78 \%$ & 13 & $4 \%$ & 0 & $0 \%$ & 3 & $3 \%$ & 4 & $3 \%$ & 3 & $4 \%$ & 14 & $17 \%$ & 15 & $15 \%$ & 23 & $29 \%$ & 290 & $23 \%$ \\
\hline & $\begin{array}{l}\text { Primary } \\
\text { (kinder to } \\
\text { 7th grade) }\end{array}$ & 61 & $22 \%$ & 273 & $94 \%$ & 66 & $55 \%$ & 22 & $23 \%$ & 43 & $27 \%$ & 48 & $64 \%$ & 47 & $56 \%$ & 48 & $49 \%$ & 44 & $56 \%$ & 652 & $51 \%$ \\
\hline & $\begin{array}{l}\text { Lower } \\
\text { Secondary } \\
\text { (8th to 9th } \\
\text { grade) }\end{array}$ & 1 & $0 \%$ & 5 & $2 \%$ & 49 & $41 \%$ & 46 & $48 \%$ & 62 & $39 \%$ & 7 & $9 \%$ & 15 & $18 \%$ & 16 & $16 \%$ & 8 & $10 \%$ & 209 & $16 \%$ \\
\hline & $\begin{array}{l}\text { Upper } \\
\text { secondary } \\
\text { (10th to 12th } \\
\text { grade) }\end{array}$ & 0 & $0 \%$ & 0 & $0 \%$ & 5 & $4 \%$ & 24 & $25 \%$ & 51 & $32 \%$ & 13 & $17 \%$ & 6 & $7 \%$ & 11 & $11 \%$ & 3 & $4 \%$ & 113 & $9 \%$ \\
\hline & $\begin{array}{l}\text { Tertiary } \\
\text { education }\end{array}$ & 0 & $0 \%$ & 0 & $0 \%$ & 0 & $0 \%$ & 1 & $1 \%$ & 0 & $0 \%$ & 4 & $5 \%$ & 2 & $2 \%$ & 7 & $7 \%$ & 0 & $0 \%$ & 14 & $1 \%$ \\
\hline & Total & 277 & $100 \%$ & 291 & $100 \%$ & 120 & $100 \%$ & 96 & $100 \%$ & 160 & $100 \%$ & 75 & $100 \%$ & 84 & $100 \%$ & 97 & $100 \%$ & 78 & $100 \%$ & 1278 & $100 \%$ \\
\hline
\end{tabular}

Educational level reached and not necessarily passed

Note: Due to missing answers the total is not the same as the total number of household members, plus the respondents answers are not portrayed here. There was a significant amount of missing values for spouse's education so they may not be properly reflected. 
The educational levels reached by household members were analysed by gender and age. Table 17 shows the educational level reached (by gender) of members 19 or younger, and Table 19 of members 20 years or older. They show very interesting differences between the age groups; in the younger generation, there is no particular preference for male education whilst this is evident in the older generation. There are no differences in the percentage of boys and girls that are in primary (0-19 age group) while there is a slight difference in lower secondary with a higher percentage of girls at that level. This could be due to the fact that there are more girls (than boys) aged 14 to 16 which is the age range of this schooling level, but there is a difference in the numbers reaching upper secondary, with more boys attaining the higher level. This may appear to be due to the fact that there are more boys of that age (17-19) than girls, but if we take into account the fact that more girls are leaving their household at that age to form their own household, this indicates that completing school education is still not considered as important for girls. Another reason that girls leave school early is due to the incidence of early pregnancies when they are forced to leave school and usually may not return to complete their education. In Table 18, gender differences in education are quite evident: of all the people who have no education, $94 \%$, are women, and of the members that have reached upper secondary, $70 \%$ are men. This shows a significant preference for men's education in the previous generations, which is consistent with comments in qualitative interviews.

Table 17. Household members' educational level by gender (0-19 years old)

\begin{tabular}{|c|c|c|c|c|c|c|c|}
\hline & & \multicolumn{4}{|c|}{$\begin{array}{c}\text { Gender of household members } \\
0-19 \text { years old }\end{array}$} & \multirow{2}{*}{\multicolumn{2}{|c|}{ Total }} \\
\hline & & \multicolumn{2}{|c|}{ Female } & \multicolumn{2}{|c|}{ Male } & & \\
\hline & & Count & \begin{tabular}{|c|c|} 
Column N \\
$\%$
\end{tabular} & Count & $\underset{\%}{\text { Column N }}$ & Count & $\underset{\%}{\text { Column N }}$ \\
\hline \multirow{5}{*}{$\begin{array}{c}\text { Household member } \\
\text { educational level } \\
\text { reached }^{\star}\end{array}$} & None & 115 & $29.6 \%$ & 116 & $29.3 \%$ & 231 & $29.5 \%$ \\
\hline & $\begin{array}{l}\text { Primary } \\
\text { (kinder to } 7^{\text {th }} \text { grade) }\end{array}$ & 202 & $52.1 \%$ & 220 & $55.6 \%$ & 422 & $53.8 \%$ \\
\hline & $\begin{array}{l}\text { Lower Secondary } \\
\left(8^{\text {th }} \text { to } 9^{\text {th }} \text { grade }\right)\end{array}$ & 61 & $15.7 \%$ & 40 & $10.1 \%$ & 101 & $12.9 \%$ \\
\hline & $\begin{array}{l}\text { Upper secondary } \\
\left(10^{\text {th }} \text { to } 12^{\text {th }} \text { grade }\right)\end{array}$ & 9 & $2.3 \%$ & 20 & $5.1 \%$ & 29 & $3.7 \%$ \\
\hline & Tertiary education & 1 & $0.3 \%$ & 0 & $0.0 \%$ & 1 & $0.1 \%$ \\
\hline \multicolumn{2}{|c|}{ Total } & 388 & $100 \%$ & 396 & $100 \%$ & 784 & $100 \%$ \\
\hline
\end{tabular}

* Educational level reached and not necessarily passed

Table 18. Household members' educational level by gender (20 years old and older)

\begin{tabular}{|c|c|c|c|c|c|c|c|}
\hline & & \multicolumn{4}{|c|}{$\begin{array}{c}\text { Gender of household members } 20 \\
\text { and older }\end{array}$} & \multirow{2}{*}{\multicolumn{2}{|c|}{ Total }} \\
\hline & & \multicolumn{2}{|c|}{ Female } & \multicolumn{2}{|c|}{ Male } & & \\
\hline & & Count & $\begin{array}{c}\text { Column N } \\
\% \\
\end{array}$ & Count & $\begin{array}{c}\text { Column N } \\
\% \\
\end{array}$ & Count & $\begin{array}{c}\text { Column N } \\
\% \\
\end{array}$ \\
\hline \multirow{5}{*}{$\begin{array}{c}\text { Household } \\
\text { member } \\
\text { educational level } \\
\text { reached }^{*}\end{array}$} & None & 50 & $20.0 \%$ & 9 & $3.6 \%$ & 59 & $11.8 \%$ \\
\hline & \begin{tabular}{|l|}
$\begin{array}{l}\text { Primary } \\
\text { (kinder to } 7^{\text {th }} \text { grade) }\end{array}$ \\
\end{tabular} & 142 & $56.8 \%$ & 88 & $35.5 \%$ & 230 & $46.2 \%$ \\
\hline & $\begin{array}{l}\text { Lower Secondary } \\
\left(8^{\text {th }} \text { to } 9^{\text {th }} \text { grade }\right)\end{array}$ & 36 & $14.4 \%$ & 72 & $29.0 \%$ & 108 & $21.7 \%$ \\
\hline & $\begin{array}{l}\text { Upper secondary } \\
\left(10^{\text {th }} \text { to } 12^{\text {th }} \text { grade }\right)\end{array}$ & 18 & $7.2 \%$ & 66 & $26.6 \%$ & 84 & $16.9 \%$ \\
\hline & Tertiary education & 3 & $1.2 \%$ & 10 & $4.0 \%$ & 13 & $2.6 \%$ \\
\hline \multicolumn{2}{|c|}{ Total } & 250 & $100 \%$ & 248 & $100 \%$ & 498 & $100 \%$ \\
\hline
\end{tabular}

${ }^{*}$ School level reached and not necessarily passed 


\subsection{Education of sons and daughters not living at home}

The education of children no longer living at home follows the same gender pattern as the previous sections; more men have reached higher educational levels than women. In general, $11 \%$ of household members not living at home have no education, $47 \%$ have reached primary, $24 \%$ lower secondary, $16 \%$ upper secondary, and only $2 \%$ tertiary education. The results in Table 19 show a lower percentage or men $(8 \%)$ than women $(12.9 \%)$ have no education. The reverse happens for those who have reached upper secondary, as $25.3 \%$ of men have reached that level while for women the percentage is only $9.1 \%$. Again, the higher educational level achieved by men demonstrates a preference for male education.

Table 19. Sons and daughters not living at home: education by gender

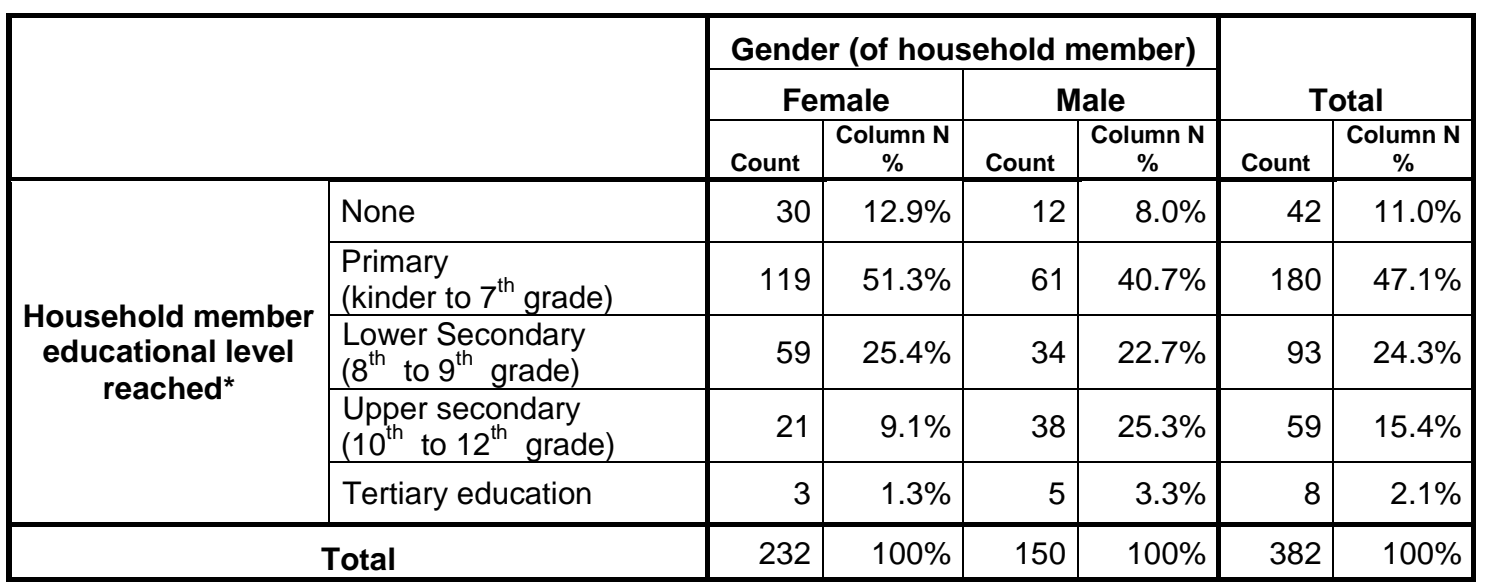

${ }^{*}$ Educational level reached and not necessarily passed.

\section{Status}

In this section participants were asked if any household member held a special position in the community and $22 \%$ responded affirmatively. Table 20 shows that if we analyse the data by gender/marital status, more married men (26\%) than single women (10\%) occupy a position of status.

Table 20. Household member with special position in the community by gender/marital status.

\begin{tabular}{|c|c|c|c|c|c|c|c|c|c|}
\hline & & \multicolumn{6}{|c|}{ Gender/Marital Status } & \multirow{2}{*}{\multicolumn{2}{|c|}{ Total }} \\
\hline & & \multicolumn{2}{|c|}{ Married Men } & \multicolumn{2}{|c|}{ Married Women } & \multicolumn{2}{|c|}{ Single Women } & & \\
\hline & & Count & $\begin{array}{c}\text { Column } \\
\mathrm{N} \%\end{array}$ & Count & $\begin{array}{c}\text { Column } \\
\mathrm{N} \%\end{array}$ & Count & $\begin{array}{c}\text { Column } \\
\mathrm{N} \%\end{array}$ & Count & $\begin{array}{c}\text { Column } \\
\mathrm{N} \%\end{array}$ \\
\hline \multirow{2}{*}{$\begin{array}{l}\text { Household member with } \\
\text { special position in the } \\
\text { community }\end{array}$} & No & $110_{a}$ & $74 \%$ & $130_{a, b}$ & $78 \%$ & $47 \mathrm{~b}$ & $90 \%$ & 287 & $78 \%$ \\
\hline & Yes & $38_{a}$ & $26 \%$ & $36_{a, b}$ & $22 \%$ & $5 b$ & $10 \%$ & 79 & $22 \%$ \\
\hline \multicolumn{2}{|l|}{ Total } & 148 & $100 \%$ & 166 & $100 \%$ & 52 & $100 \%$ & 366 & $100 \%$ \\
\hline
\end{tabular}

Note: Values in the same row and sub-table not sharing the same subscript are significantly different at $p<.05$ in the twosided test of equality for column proportions. Cells with no subscript are not included in the test. Tests assume equal

Tests are adjusted for all pairwise comparisons within a row of each innermost sub-table using the Bonferroni correction.

$43(12 \%)$ of respondents reported that they themselves held a special position. When we analysed this by gender/marital status there was a clear and statistically significant distinction between married men (20\% have a special position) and married women (only $5 \%$ have one). Interestingly, more single women $(10 \%)$ than married women had a special position, but the differences were not significant with respect either to married men or women. This signals that men have more of a say in community affairs than women. 
Table 21. Respondent with special position in the community by gender/marital status

\begin{tabular}{|c|c|c|c|c|c|c|c|c|c|}
\hline & & \multicolumn{6}{|c|}{ Gender/Marital Status } & \multirow{3}{*}{\multicolumn{2}{|c|}{ Total }} \\
\hline & & \multicolumn{2}{|c|}{ Married Men } & \multicolumn{2}{|c|}{ Married Women } & \multicolumn{2}{|c|}{ Single Women } & & \\
\hline & & Count & $\begin{array}{c}\text { Column N } \\
\%\end{array}$ & Count & \begin{tabular}{|c|} 
Column N \\
$\%$
\end{tabular} & Count & $\begin{array}{c}\text { Column N } \\
\%\end{array}$ & & \\
\hline \multirow{2}{*}{$\begin{array}{l}\text { Respondent has } \\
\text { special position in } \\
\text { the community }\end{array}$} & No & $119_{a}$ & $80 \%$ & $157_{b}$ & $95 \%$ & $47_{\mathrm{a}, \mathrm{b}}$ & $90 \%$ & 323 & $88 \%$ \\
\hline & Yes & $29 a$ & $20 \%$ & $9 \mathrm{~b}$ & $5 \%$ & $5 a, b$ & $10 \%$ & 43 & $12 \%$ \\
\hline \multicolumn{2}{|l|}{ Total } & 148 & $100 \%$ & 166 & $100 \%$ & 52 & $100 \%$ & 366 & $100 \%$ \\
\hline
\end{tabular}

Note: Values in the same row and sub-table not sharing the same subscript are significantly different at $p<.05$ in the two-sided test of equality for column proportions. Cells with no subscript are not included in the test. Tests assume equal variances. Tests are adjusted for all pairwise comparisons within a row of each innermost sub-table using the Bonferroni correction.

We analysed differences in gender, education and type of position within all of the household members (including respondents) who were reported as having a position. The 79 respondents that said that a household member has a special position in the community represent 55 households. 21 of these 55 households do not agree on the answer, and either the husband or the wife says that someone has a special position but the other does not acknowledge this. To avoid duplicates and ensure that we had complete information we kept every case in which at least one of the spouse said that someone had a special position and we then compared the cases in which both spouses said there was a member with a special position. When the data matched and the spouses were referring to the same person, the data from the household head was kept and the spouse's was set aside. After doing this, we had a database of 66 people, 21 females and 41 males (from 55 households) that had a special position in the community. As in the household members sections, due to the characteristics of the data, the following tables and analysis in this section have been produced with a different method, and statistically significant differences could not be assessed.

The majority of people who have a special position are the household heads (68\%), followed by spouses (29\%) but household heads are usually male (and spouses female), and there are therefore more males with a special position than women (Table 22).

Table 22. Household member with special position: Relation to household head by gender

\begin{tabular}{|c|c|c|c|c|c|c|c|}
\hline & & \multicolumn{4}{|c|}{$\begin{array}{c}\text { Gender } \\
\text { (of household member) }\end{array}$} & \multirow{2}{*}{\multicolumn{2}{|c|}{ Total general }} \\
\hline & & \multicolumn{2}{|c|}{ Female } & \multicolumn{2}{|c|}{ Male } & & \\
\hline & & Count & $\underset{\%}{\text { Column N }}$ & Count & $\underset{\%}{\text { Column N }}$ & Count & $\underset{\%}{\text { Column N }}$ \\
\hline \multirow{4}{*}{$\begin{array}{c}\text { Household member } \\
\text { with special position: } \\
\text { Relation to Household } \\
\text { head }\end{array}$} & Household head & 5 & $20 \%$ & 40 & $98 \%$ & 45 & $68 \%$ \\
\hline & Parent & 0 & $0 \%$ & 1 & $2 \%$ & 1 & $2 \%$ \\
\hline & Parent-in-law & 1 & $4 \%$ & 0 & $0 \%$ & 1 & $2 \%$ \\
\hline & Spouse & 19 & $76 \%$ & 0 & $0 \%$ & 19 & $29 \%$ \\
\hline \multicolumn{2}{|c|}{ Total } & 25 & $100 \%$ & 41 & $100 \%$ & 66 & $100 \%$ \\
\hline
\end{tabular}

Table 23 shows that the most common special position is church leader (42\%). In absolute terms, more men are church leaders than women (15 men to 13 women). However, for women these church leadership roles accounted for $52 \%$ of the special positions held, while for men they accounted for only $37 \%$. There is a large cohort with other positions not classified in the survey $(23 \%)$ and this is more common amongst women than men (32\% of women, compared to $17 \%$ of men). The third most common position is headman or vice-headman (18\% of the total) and this position is almost exclusively ascribed to men (only 1 woman has this position). 
Table 23. Household member with special position: Position by gender

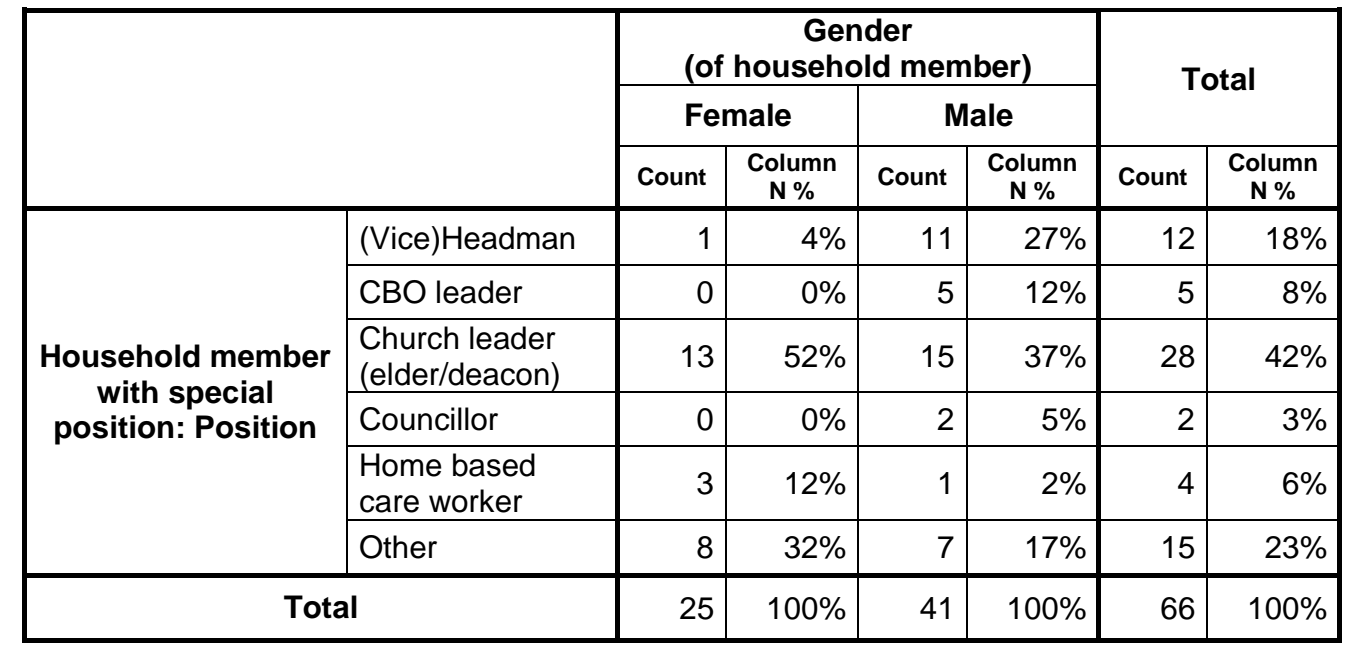

\section{Health and disability}

\subsection{General state of health}

In general, respondents feel positive about their state of health and the majority report that it is neither good nor bad (43\%), followed by generally good (37\%), and very good (14\%). But when comparing this between gender/marital groups (Table 24), it is evident that single women's health is not as good as married women's. Only $8 \%$ of single women report having very good health while $23 \%$ of married men say so. Married women also report significantly poorer health than married men. When comparing the mean scores for each group in this question (maximum 5, minimum 1), it is clearer that men report to have a better state of health; women's mean score is 3.81 , within that married women score 3.51 and single women 3.25. The differences were statistically significant when comparing men to both groups of women. The relationship between health and wellbeing will be explored further later in this report. It is also widely known that men tend to underreport their health problems and this also needs to be taken into account when analysing these results.

Table 24. General state of health by gender/marital status

\begin{tabular}{|c|c|c|c|c|c|c|c|c|c|}
\hline & & \multicolumn{6}{|c|}{ Gender/Marital Status } & \multirow{2}{*}{\multicolumn{2}{|c|}{ Total }} \\
\hline & & \multicolumn{2}{|c|}{ Married Men } & \multicolumn{2}{|c|}{$\begin{array}{l}\text { Married } \\
\text { Women }\end{array}$} & \multicolumn{2}{|c|}{ Single Women } & & \\
\hline & & Count & $\underset{\%}{\text { Column } \mathbf{N}}$ & Count & $\begin{array}{c}\text { Column N } \\
\%\end{array}$ & Count & $\underset{\%}{\text { Column } \mathbf{N}}$ & Count & $\underset{\%}{\text { Column N }}$ \\
\hline \multirow{5}{*}{$\begin{array}{l}\text { General state } \\
\text { of health }\end{array}$} & Very bad & $1 \mathrm{a}$ & $1 \%$ & $0^{1}$ & $0 \%$ & $0^{1}$ & $0 \%$ & 1 & $0 \%$ \\
\hline & Rather bad & $4 a$ & $3 \%$ & $10_{a, b}$ & $6 \%$ & $6 b$ & $12 \%$ & 20 & $5 \%$ \\
\hline & $\begin{array}{l}\text { Neither good } \\
\text { nor bad }\end{array}$ & $51_{a}$ & $34 \%$ & $76_{a, b}$ & $46 \%$ & $31_{b}$ & $60 \%$ & 158 & $43 \%$ \\
\hline & Generally good & $58 a$ & $39 \%$ & $65 a$ & $39 \%$ & $11_{a}$ & $21 \%$ & 134 & $37 \%$ \\
\hline & Very good & $34 a$ & $23 \%$ & $15 b$ & $9 \%$ & $4 b$ & $8 \%$ & 53 & $14 \%$ \\
\hline \multicolumn{2}{|c|}{ Total } & 148 & $100 \%$ & 166 & $100 \%$ & 52 & $100 \%$ & 366 & $100 \%$ \\
\hline
\end{tabular}

Note: Values in the same row and sub-table not sharing the same subscript are significantly different at $p<.05$ in the twosided test of equality for column proportions. Cells with no subscript are not included in the test. Tests assume equal variances. Categories with column proportions equal to zero or one are not used in comparisons. Tests are adjusted for all pairwise comparisons within a row of each innermost sub-table using the Bonferroni correction. 
Mean scores were also compared for each age group, and Table 25 shows that respondents in the 18 to 29 age group report a statistically significant higher state of health (3.79) than respondents aged 50 or older (3.38). The differences in other age groups are not statistically significant, but the older the person, the lower the mean score. This is an expected finding since older people tend to suffer more from health issues.

Table 25. General state of health by age groups

\begin{tabular}{|c|c|c|c|c|c|}
\hline & \multicolumn{5}{|c|}{ Age groups } \\
\hline & 18 to 29 years & 30 to 34 years & 35 to 39 years & 40 to 49 years & 50 and up \\
\hline & Mean & Mean & Mean & Mean & Mean \\
\hline General state of health & $3,79_{a}$ & $3,60_{a, b}$ & $3,73_{a, b}$ & $3,62_{a, b}$ & $3,38_{b}$ \\
\hline
\end{tabular}

Note: Values in the same row and sub-table not sharing the same subscript are significantly different at $p<.05$ in the two-sided test of equality for column means. Cells with no subscript are not included in the test. Tests assume equal variances.

Tests are adjusted for all pairwise comparisons within a row of each innermost sub-table using the Bonferroni correction.

\subsection{Seeking help for health problems}

The vast majority of respondents $(79 \%)$ have sought help for themselves or others in the past six months, and no statistically significant differences were found between men and women with or without taking into account their marital status. Regardless of their marital status or gender, therefore, the majority of people have sought help in health services either for themselves or others. Table $26^{8}$ shows the specific health services visited by gender/marital status. The most visited health service is the primary health centre which was visited by $82 \%$ of respondents (who reported having sought help in the past six months), followed by the Mission Hospital (Chirundu) visited by $27 \%$ of people and finally faith healers who were visited by $9 \%$ of respondents. In the qualitative interviews, people reported more contact and visits to n'gangas (diviners) than is reflected here, and people may have visited them more than they have reported. A statistical difference between marital status was only found in one response; the Primary Health centre was visited more by married women (88\%) than single women $(71 \%)$. No statistically significant gender differences were found in any of these comparisons.

\footnotetext{
${ }^{8}$ This table, as well as the next one, is an amalgamation of several variables as respondents were asked if they visited each of these services. This means that the row totals are not pertinent as people could have visited more than one health service. Additionally, to make reading easier, the count and percentages of respondents that said that they have not visited each service were set aside. Consequently, the total column \% does not add up to 100.
} 
Table 26. Health services visited by gender/marital status

\begin{tabular}{|c|c|c|c|c|c|c|c|c|c|}
\hline & & \multicolumn{6}{|c|}{ Gender/Marital Status } & \multirow{2}{*}{\multicolumn{2}{|c|}{ Total }} \\
\hline & & \multicolumn{2}{|c|}{ Married Men } & \multicolumn{2}{|c|}{$\begin{array}{l}\text { Married } \\
\text { Women }\end{array}$} & \multicolumn{2}{|c|}{ Single Women } & & \\
\hline & & Count & $\begin{array}{c}\text { Column N } \\
\%\end{array}$ & Count & $\begin{array}{c}\text { Column N } \\
\%\end{array}$ & Count & $\begin{array}{c}\text { Column N } \\
\%\end{array}$ & Count & $\underset{\%}{\text { Column } \mathbf{N}}$ \\
\hline Faith healer & Yes & $6 a$ & $5 \%$ & $19 a$ & $14 \%$ & $2 \mathrm{a}$ & $5 \%$ & 27 & $9 \%$ \\
\hline N'ganga & Yes & $2 a$ & $2 \%$ & $1_{\mathrm{a}}$ & $1 \%$ & $1_{a}$ & $2 \%$ & 4 & $1 \%$ \\
\hline Herbalist & Yes & $4 a$ & $4 \%$ & $4 a$ & $3 \%$ & $1_{\mathrm{a}}$ & $2 \%$ & 9 & $3 \%$ \\
\hline Community Health Worker & Yes & $1 \mathrm{a}$ & $1 \%$ & $0^{1}$ & $0 \%$ & $0^{1}$ & $0 \%$ & 1 & $0 \%$ \\
\hline Primary Health Centre & Yes & $89_{a, b}$ & $80 \%$ & $121_{a}$ & $88 \%$ & $29_{b}$ & $71 \%$ & 239 & $82 \%$ \\
\hline Mission hospital (Chirundu) & Yes & $32 a$ & $29 \%$ & $36 a$ & $26 \%$ & $10_{a}$ & $24 \%$ & 78 & $27 \%$ \\
\hline Lusaka (public hospital) & Yes & $1_{a}$ & $1 \%$ & $2 a$ & $1 \%$ & $1_{\mathrm{a}}$ & $2 \%$ & 4 & $1 \%$ \\
\hline Other health provider & Yes & $2 a$ & $2 \%$ & $0^{1}$ & $0 \%$ & $1 \mathrm{a}$ & $2 \%$ & 3 & $1 \%$ \\
\hline
\end{tabular}

Note: Values in the same row and sub-table not sharing the same subscript are significantly different at $\mathrm{p}<.05$ in the twosided test of equality for column proportions. Cells with no subscript are not included in the test. Tests assume equal variances. Categories with column proportions equal to zero or one are not used in comparisons. Tests are adjusted for all pairwise comparisons within a row of each innermost sub-table using the Bonferroni correction.

Table 27 shows the reasons for visiting these health services. Faith healers are visited mostly for chronic conditions ( $41 \%$ of visits to faith healers) which include diabetes, blood pressure, asthma, bronchitis, back or joint pains, epilepsy). $37 \%$ of visits to faith healers were for reasons not classified in our survey. The most common reasons for attending the primary health centre were malaria $(28 \%)$, fever, coughs or colds (14\%), and chronic conditions (22\%). The mission hospital (Chirundu) is mainly visited for chronic conditions (31\%), malaria (8\%) and issues not classified in our survey $(38 \%)$. 
Table 27. Reason for visiting health service by health service

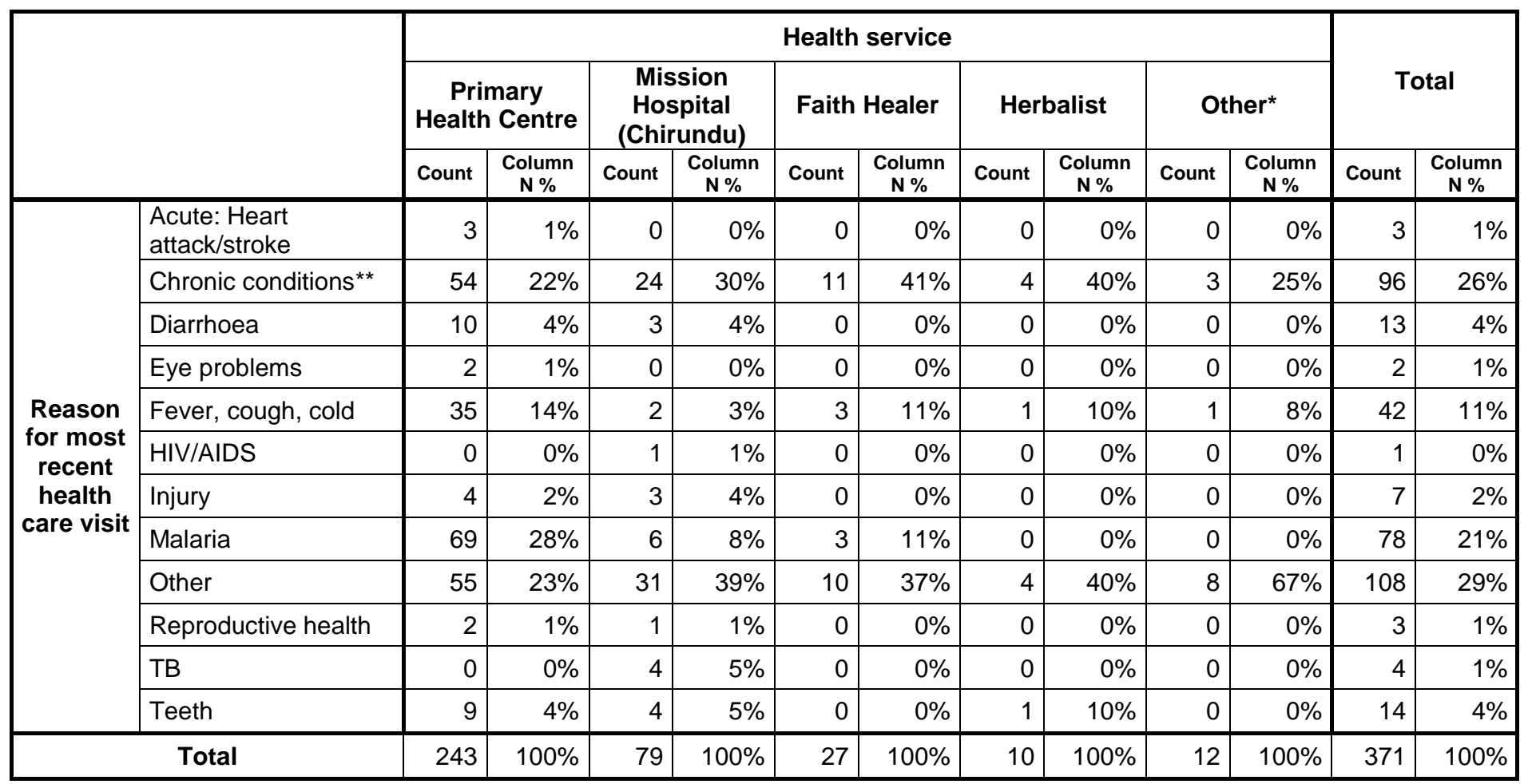

*Includes: Other, Community health worker, Lusaka and Nganga

${ }^{\star \star}$ Chronic conditions include: diabetes, blood pressure, asthma, bronchitis, back or join pains, epilepsy

Note: Due to the characteristics of the data statistically significant differences could not be assessed.

Table 28 shows that most respondents who sought healthcare (53\%) say that they went on their own behalf. The next most common reason for going was a child $(25 \%)$ and then other household members or their spouses ( $9 \%$ each). Due to the characteristics and structuring of the data, statistically significant differences were not assessed, but nonetheless it is interesting that proportionately more women (either single or married) report seeking health help for themselves than married men, and that proportionately more married men reported seeking help for their spouses than married women. This is consistent with the previous results of perceived general state of health; either women's health is not as good as men's or it could also be that men underreport their own health problems. 
Table 28. Household member with most recent health problem

\begin{tabular}{|c|c|c|c|c|c|c|c|c|c|}
\hline & \multicolumn{6}{|c|}{ Gender/Marital Status } & \multirow{2}{*}{\multicolumn{2}{|c|}{ Total }} \\
\hline & & \multicolumn{2}{|c|}{ Married Men } & \multicolumn{2}{|c|}{ Married Women } & \multicolumn{2}{|c|}{ Single Women } & & \\
\hline & & Count & Column N \% & Count & Column N \% & Count & Column N \% & Count & Column N \% \\
\hline \multirow{6}{*}{ 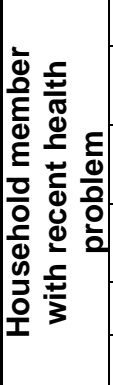 } & Child & 34 & $25 \%$ & 47 & $26 \%$ & 11 & $25 \%$ & 92 & $25 \%$ \\
\hline & $\begin{array}{l}\text { Other household } \\
\text { member }\end{array}$ & 15 & $11 \%$ & 13 & $7 \%$ & 4 & $9 \%$ & 32 & $9 \%$ \\
\hline & $\begin{array}{l}\text { Other kin(outside } \\
\text { own household) }\end{array}$ & 3 & $2 \%$ & 7 & $4 \%$ & 0 & $0 \%$ & 10 & $3 \%$ \\
\hline & $\begin{array}{l}\text { Other non-kin-non } \\
\text { household }\end{array}$ & 0 & $0 \%$ & 1 & $1 \%$ & 0 & $0 \%$ & 1 & $0 \%$ \\
\hline & Self & 64 & $47 \%$ & 99 & $55 \%$ & 29 & $66 \%$ & 192 & $53 \%$ \\
\hline & Spouse & 20 & $15 \%$ & 14 & $8 \%$ & 0 & $0 \%$ & 34 & $9 \%$ \\
\hline \multicolumn{2}{|r|}{ Total } & 136 & $100 \%$ & 181 & $100 \%$ & 44 & $100 \%$ & 367 & $100 \%$ \\
\hline
\end{tabular}

\subsection{Disabilities}

Our question about disability was on functional impairment. Given this framing, very few respondents (only 9 , which represents $2.5 \%$ of the total sample) report having a disabling condition, and no differences arise by gender/marital status. We also asked them if their disabling condition impacted other aspects of their lives and how much difficulty they experience due to it. The results can be seen in Table 29, where more respondents appear to experience difficulty in doing activities that help to earn money, moving around to different places, and taking part in social activities.

Table 29. Impact on life by gender/marital status for respondents reporting functional impairment

\begin{tabular}{|c|c|c|c|c|c|}
\hline & & \multicolumn{3}{|c|}{ Gender/Marital Status } & \multirow[b]{2}{*}{ Total } \\
\hline & & $\begin{array}{l}\text { Married } \\
\text { Men }\end{array}$ & $\begin{array}{l}\text { Married } \\
\text { Women }\end{array}$ & $\begin{array}{l}\text { Single } \\
\text { Women }\end{array}$ & \\
\hline & & Count & Count & Count & Count \\
\hline \multirow{3}{*}{$\begin{array}{l}\text { Disability's impact for } \\
\text { working or doing } \\
\text { activities to help earn } \\
\text { money }\end{array}$} & No difficulty at all & 1 & 1 & 0 & 2 \\
\hline & $\begin{array}{l}\text { Some difficulty , a lot of } \\
\text { difficulty or can't do at all }\end{array}$ & 2 & 3 & 2 & 7 \\
\hline & Total & 3 & 4 & 2 & 9 \\
\hline \multirow{3}{*}{$\begin{array}{l}\text { Disability's impact for } \\
\text { caring for themselves } \\
\text { day to day }\end{array}$} & No difficulty at all & 3 & 3 & 1 & 7 \\
\hline & $\begin{array}{l}\text { Some difficulty, a lot of } \\
\text { difficulty or can't do at all }\end{array}$ & 0 & 1 & 1 & 2 \\
\hline & Total & 3 & 4 & 2 & 9 \\
\hline \multirow{3}{*}{$\begin{array}{l}\text { Disability's impact for } \\
\text { moving around to } \\
\text { different places }\end{array}$} & No difficulty at all & 1 & 0 & 0 & 1 \\
\hline & $\begin{array}{l}\text { Some difficulty , a lot of } \\
\text { difficulty or can't do at all }\end{array}$ & 2 & 4 & 2 & 8 \\
\hline & Total & 3 & 4 & 2 & 9 \\
\hline \multirow{3}{*}{$\begin{array}{l}\text { Disability's impact for } \\
\text { taking part in social } \\
\text { activities }\end{array}$} & No difficulty at all & 2 & 1 & 0 & 3 \\
\hline & $\begin{array}{l}\text { Some difficulty , a lot of } \\
\text { difficulty or can't do at all }\end{array}$ & 1 & 3 & 2 & 6 \\
\hline & Total & 3 & 4 & 2 & 9 \\
\hline \multirow{3}{*}{$\begin{array}{l}\text { Disability's impact on } \\
\text { other things }\end{array}$} & No difficulty at all & 3 & 3 & 2 & 8 \\
\hline & $\begin{array}{l}\text { Some difficulty , a lot of } \\
\text { difficulty or can't do at all }\end{array}$ & 0 & 1 & 0 & 1 \\
\hline & Total & 3 & 4 & 2 & 9 \\
\hline
\end{tabular}


We also asked if anyone in the household had a mental or physical condition which left them unable to attend school or that needed someone to take care of them. Out of the 229 households in the sample, 34 households $(15 \%)$ say that there is someone with a disability in the household. But as in several previous sections, 10 couples did not answer in the same way and either the husband or the wife didn't report a disability ( 5 wives and 5 husbands didn't report as their spouse did). As in previous cases, husbands' and wives' responses were compared to avoid duplicating data. In total, 40 people with disabilities were reported and in 6 households 2 people were said to have a disability. There were several missing values in the education and/or age of the household member with disability and, due to this, the totals may vary from one table to the other. Out of the 40 household members with disabilities $41 \%$ were the sons or daughters, $18 \%$ were the household head and $10 \%$ a parent (Table 30 ).

Table 30. Household member with disability: relation to household head by gender

\begin{tabular}{|c|c|c|c|c|c|c|c|}
\hline & \multicolumn{4}{|c|}{$\begin{array}{c}\text { Gender } \\
\text { (of household member) }\end{array}$} & \multirow{2}{*}{\multicolumn{2}{|c|}{ Total }} \\
\hline & & \multicolumn{2}{|c|}{ Male } & \multicolumn{2}{|c|}{ Female } & & \\
\hline & & Count & $\begin{array}{l}\text { Column } \\
\mathrm{N} \%\end{array}$ & Count & $\begin{array}{c}\text { Column } \\
\mathrm{N} \%\end{array}$ & Count & $\begin{array}{c}\text { Column } \\
\mathrm{N} \%\end{array}$ \\
\hline \multirow{9}{*}{$\begin{array}{l}\text { Household } \\
\text { member with } \\
\text { disability: } \\
\text { relation to } \\
\text { household } \\
\text { head }\end{array}$} & Grandchild & 2 & $10 \%$ & 0 & $0 \%$ & 2 & $5 \%$ \\
\hline & $\begin{array}{l}\text { Household } \\
\text { head }\end{array}$ & 6 & $30 \%$ & 1 & $5 \%$ & 7 & $18 \%$ \\
\hline & Nephew/niece & 2 & $10 \%$ & 1 & $5 \%$ & 3 & $8 \%$ \\
\hline & Other & 1 & $5 \%$ & 0 & $0 \%$ & 1 & $3 \%$ \\
\hline & Parent & 1 & $5 \%$ & 3 & $16 \%$ & 4 & $10 \%$ \\
\hline & Sibling & 1 & $5 \%$ & 1 & $5 \%$ & 2 & $5 \%$ \\
\hline & Sibling-in-law & 1 & $5 \%$ & 0 & $0 \%$ & 1 & $3 \%$ \\
\hline & Son/daughter & 6 & $30 \%$ & 10 & $53 \%$ & 16 & $41 \%$ \\
\hline & Spouse & 0 & $0 \%$ & 3 & $16 \%$ & 3 & $8 \%$ \\
\hline \multicolumn{2}{|c|}{ Total } & 20 & $100 \%$ & 19 & $100 \%$ & 39 & 100 \\
\hline
\end{tabular}

\section{Economics and livelihoods}

\subsection{Occupation and sources of survival}

We initially analysed respondents' occupation, but found that $62.4 \%$ of married women reported their occupation as housewife. To get a better picture of what women do as a source of income and survival we therefore needed to analyse what people reported as their main source of livelihood or survival (because of widespread subsistence activities, it was not appropriate to ask about a main source of income). The most common main sources of survival (Table 31) are farming (25.2\%), safari lodge work $(9.0 \%)$, petty trading $(9 \%)$, piecework $(8.8 \%)$, and none $(14.2 \%)$. 'None' is only reported by women and is probably catching a group of housewives and unemployed single women. There are some statistically significant differences among gender/marital status groups. For example, no married men report being either unemployed or having no main source of survival, while an important percentage of married and single women do. On the other hand, craftwork is an activity only reported by married women and petty trading is reported more by women (either single or married). Finally, being a safari lodge worker is an occupation that only men report. This will be significant later on when analysing their inner wellbeing and personal economic status. 
Table 31. Main source of survival by gender marital/status

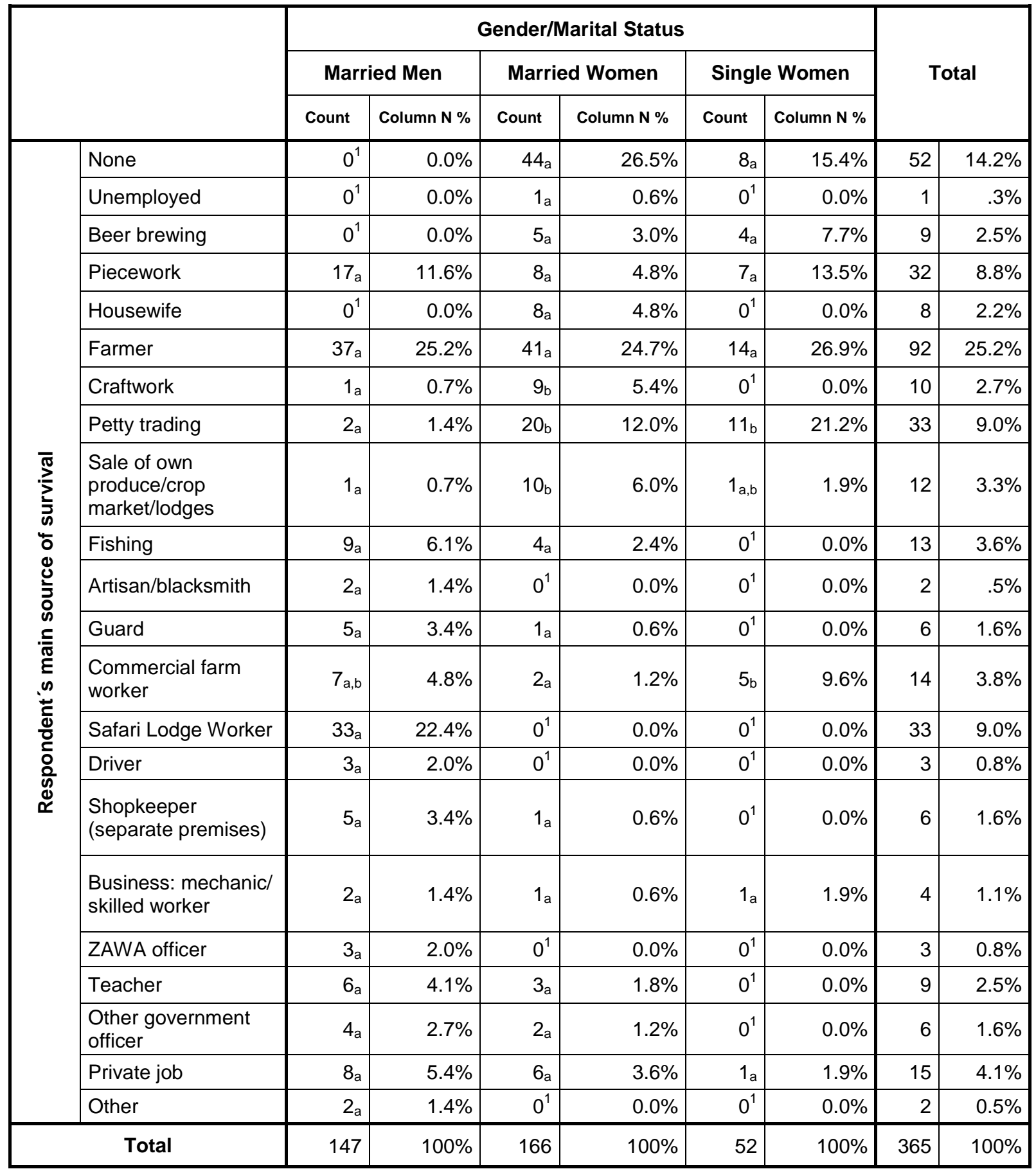

Note: Values in the same row and sub-table not sharing the same subscript are significantly different at $\mathrm{p}<, 05$ in the two-sided test of equality for column proportions. Cells with no subscript are not included in the test. Tests assume equal variances.

Tests are adjusted for all pairwise comparisons within a row of each innermost sub-table using the Bonferroni correction. 1.

This category is not used in comparisons because its column proportion is equal to zero or one.

We also asked if the respondent's source of survival was the household's main source of survival (Table 32) and all the married men answered positively, while only $19 \%$ of married women did so. This seeming inconsistency could be due to the fact that in some households we have no data for husbands. However, it could also suggest that married women are more likely than their husbands to see women's economic activities as significant to the household as a whole. Survey notes indicate that women were much more likely to say that both incomes contributed equally to the running of the household. In the 
case of single women $80 \%$ of them state that theirs is the main source of survival of the household; the differences with married women are statistically significant.

Additionally, most of the respondents who answered that theirs is not the main source of survival (148 people) said that their households depended on the household head (92.6\%). A small minority (2.7\%) declared that the household depended on their sons' or daughters' economic activities. Safari lodge worker $(32 \%)$, piecework $(12 \%)$ and farming $(12 \%)$ were the main sources of survival that were most mentioned by these respondents.

Table 32. Responsibility of source of survival by gender/marital status

\begin{tabular}{|c|c|c|c|c|c|c|c|c|c|}
\hline & & \multicolumn{6}{|c|}{ Gender/Marital Status } & \multirow{3}{*}{\multicolumn{2}{|c|}{ Total }} \\
\hline & & \multicolumn{2}{|c|}{ Married Men } & \multicolumn{2}{|c|}{$\begin{array}{l}\text { Married } \\
\text { Women }\end{array}$} & \multicolumn{2}{|c|}{ Single Women } & & \\
\hline & & Count & $\underset{\%}{\text { Column }} \mathbf{N}$ & Count & $\underset{\%}{\text { Column }} \mathbf{N}$ & Count & $\underset{\%}{\text { Column }} \mathbf{N}$ & & \\
\hline $\begin{array}{l}\text { Over the past } 12 \text { months } \\
\text { was yours the main } \\
\text { source on which your } \\
\text { household depended for } \\
\text { survival? }\end{array}$ & Yes & $147^{1}$ & $100 \%$ & $31_{a}$ & $19 \%$ & $40_{b}$ & $82 \%$ & 218 & $60 \%$ \\
\hline
\end{tabular}

Note: Values in the same row and sub-table not sharing the same subscript are significantly different at $p<.05$ in the two-sided test of equality for column proportions. Cells with no subscript are not included in the test. Tests assume equal variances. Tests are adjusted for all pairwise comparisons within a row of each innermost sub-table using the Bonferroni correction.

1. This category is not used in comparisons because its column proportion is equal to zero or one.

\subsection{Farming}

As seen in the previous section, farming is a prominent occupation and source of survival and respondents had planted crops even when their main source of survival was not being a farmer. The results showed that the vast majority (78\%) had planted crops in the past 12 months (no significant differences were found in gender/marital status). We also asked which crops were planted and in the case of maize, which is the primary staple crop, we also asked if they had harvested it and how much they yielded. The results in Table 33 confirm that maize is the crop that is planted the most (planted by $90 \%$ of the respondents that had planted crops) and that groundnuts, cotton and sorghum are less popular and only around $11 \%$ to $12 \%$ of the people that planted any crops planted them. What is significant and worrying is that in spite of maize being planted in such high numbers, only $37 \%$ of people managed to harvest it. This reflects the combination of flooding when the Kariba dam spillways were opened upstream early in the planting season, a drought that affected the region, and crop damage from wild animals.

Table 33. Distribution of crops planted by gender/marital status

\begin{tabular}{|c|c|c|c|c|c|c|c|c|c|}
\hline & & \multicolumn{6}{|c|}{ Gender/Marital Status } & \multirow{3}{*}{\multicolumn{2}{|c|}{ Total }} \\
\hline & & \multicolumn{2}{|c|}{ Married Men } & \multicolumn{2}{|c|}{$\begin{array}{l}\text { Married } \\
\text { Women }\end{array}$} & \multicolumn{2}{|c|}{ Single Women } & & \\
\hline & & Count & $\begin{array}{c}\text { Column N } \\
\%\end{array}$ & Count & $\underset{\%}{\text { Column N }}$ & Count & $\begin{array}{c}\text { Column N } \\
\%\end{array}$ & & \\
\hline Maize planted & Yes & 105 & $91 \%$ & 116 & $91 \%$ & 35 & $85 \%$ & 256 & $90 \%$ \\
\hline Maize harvested & Yes & 51 & $44 \%$ & 40 & $31 \%$ & 15 & $37 \%$ & 106 & $37 \%$ \\
\hline Groundnuts harvested & Yes & 12 & $10 \%$ & 15 & $12 \%$ & 5 & $13 \%$ & 32 & $11 \%$ \\
\hline Cotton harvested & Yes & 19 & $17 \%$ & 13 & $10 \%$ & 3 & $8 \%$ & 35 & $12 \%$ \\
\hline Sorghum harvested & Yes & 14 & $12 \%$ & 14 & $11 \%$ & 6 & $15 \%$ & 34 & $12 \%$ \\
\hline Other harvested & Yes & 6 & $5 \%$ & 4 & $3 \%$ & 1 & $3 \%$ & 11 & $4 \%$ \\
\hline
\end{tabular}

Note: No statistically significant differences were found 
The respondents that harvested maize managed to produce an average 422 kilos each with slight differences between gender/marital groups. Women in general, and especially single women, seem to have harvested less, but the differences were not statistically significant (Table 34). This allowed respondents, on average, to eat the maize they grew themselves for 6 months (no differences found in gender/ marital status). In Table 35, the number of months that people ate their own maize has been separated into groups to allow for more detailed comparisons between groups, and it can be seen that, whilst respondents ate their own maize for an average of 6 months, $30 \%$ were only sustained by their own maize for 1-3 months, while around the same percentage ate their own maize for most of the year.

Table 34. Amount of maize harvested by gender/marital status

\begin{tabular}{|l|r|r|r|r|}
\hline \multirow{2}{*}{} & \multicolumn{2}{|c|}{ Gender/Marital Status } & \multirow{2}{*}{ Total } \\
\cline { 2 - 4 } & $\begin{array}{c}\text { Married } \\
\text { Men }\end{array}$ & $\begin{array}{l}\text { Married } \\
\text { Women }\end{array}$ & $\begin{array}{c}\text { Single } \\
\text { Women }\end{array}$ & \\
\cline { 2 - 4 } & Mean & Mean & Mean & Mean \\
\hline $\begin{array}{l}\text { How much maize have you } \\
\text { harvested in kilos? }\end{array}$ & 404 & 455 & 390 & 422 \\
\hline
\end{tabular}

Table 35. Number of months eating own grown maize by gender/marital status

\begin{tabular}{|c|c|c|c|c|c|c|c|c|c|}
\hline & & \multicolumn{6}{|c|}{ Gender/Marital Status } & \multirow{3}{*}{\multicolumn{2}{|c|}{ Total }} \\
\hline & & \multicolumn{2}{|c|}{ Married Men } & \multicolumn{2}{|c|}{$\begin{array}{l}\text { Married } \\
\text { Women }\end{array}$} & \multicolumn{2}{|c|}{ Single Women } & & \\
\hline & & Count & $\begin{array}{c}\text { Column N } \\
\%\end{array}$ & Count & $\begin{array}{c}\text { Column N } \\
\%\end{array}$ & Count & $\begin{array}{c}\text { Column N } \\
\%\end{array}$ & & \\
\hline \multirow{5}{*}{$\begin{array}{c}\text { Number of } \\
\text { months eating } \\
\text { own grown } \\
\text { maize }\end{array}$} & None & 0 & $0 \%$ & 1 & $3 \%$ & 0 & $0 \%$ & 1 & $1 \%$ \\
\hline & $1-3$ months & 15 & $30 \%$ & 12 & $30 \%$ & 4 & $27 \%$ & 31 & $30 \%$ \\
\hline & 4-6 months & 16 & $32 \%$ & 15 & $38 \%$ & 5 & $33 \%$ & 36 & $34 \%$ \\
\hline & 7-9 months & 5 & $10 \%$ & 0 & $0 \%$ & 2 & $13 \%$ & 7 & $7 \%$ \\
\hline & $10-12$ months & 14 & $28 \%$ & 12 & $30 \%$ & 4 & $27 \%$ & 30 & $29 \%$ \\
\hline \multicolumn{2}{|c|}{ Total } & 50 & $100 \%$ & 40 & $100 \%$ & 15 & $100 \%$ & 105 & $100 \%$ \\
\hline
\end{tabular}

Note: No significant differences were found

\subsection{Living environment and assets}

Most households have a latrine (80\%), mobile phone (73\%) and chickens (68\%). 49\% have a radio and $42 \%$ a bicycle (see Table 36 ). ${ }^{9}$ As can be seen, not many statistically significant differences arise by gender/marital status, except that a significantly lower percentage of single women $(17 \%)$ have a television set than married men (43\%) and married women (45\%). The same divide arises in owning a radio: only $21 \%$ of single women own one as compared to $57 \%$ of married men and $51 \%$ of married women. The same pattern arises in ownership of a mobile phone. Again fewer single women (56\%) than married men (80\%) report having one, though in this last case the differences between single and married women are not statistically significant. Additionally, it is noteworthy that there are statistically significant differences between the three groups in owning a bicycle; more married men $(55 \%)$ than married women (39\%) and single women (17\%) report having one. This difference in assets between single women and married people, specifically in the more modern communication assets and their means of moving around (bicycles), could be affecting their access to information and communication.

It must be noted that due to the method of analysing statistically significant differences some comparisons result in being not statistically significant when no-one from one group has answered positively (e.g. no single women own cattle or a water pump). This result highlights the poorer assets of single women despite this not being picked up by the statistical analysis.

${ }^{9}$ This table is also an amalgamation of several variables. Respondents were asked if they have each of these assets and so row totals are not pertinent, as people can have more than one. In order to make reading easier, the count and percentages of respondents that said that they did not have the asset were set aside, and for that reason the total column \% does not add to 100 . 


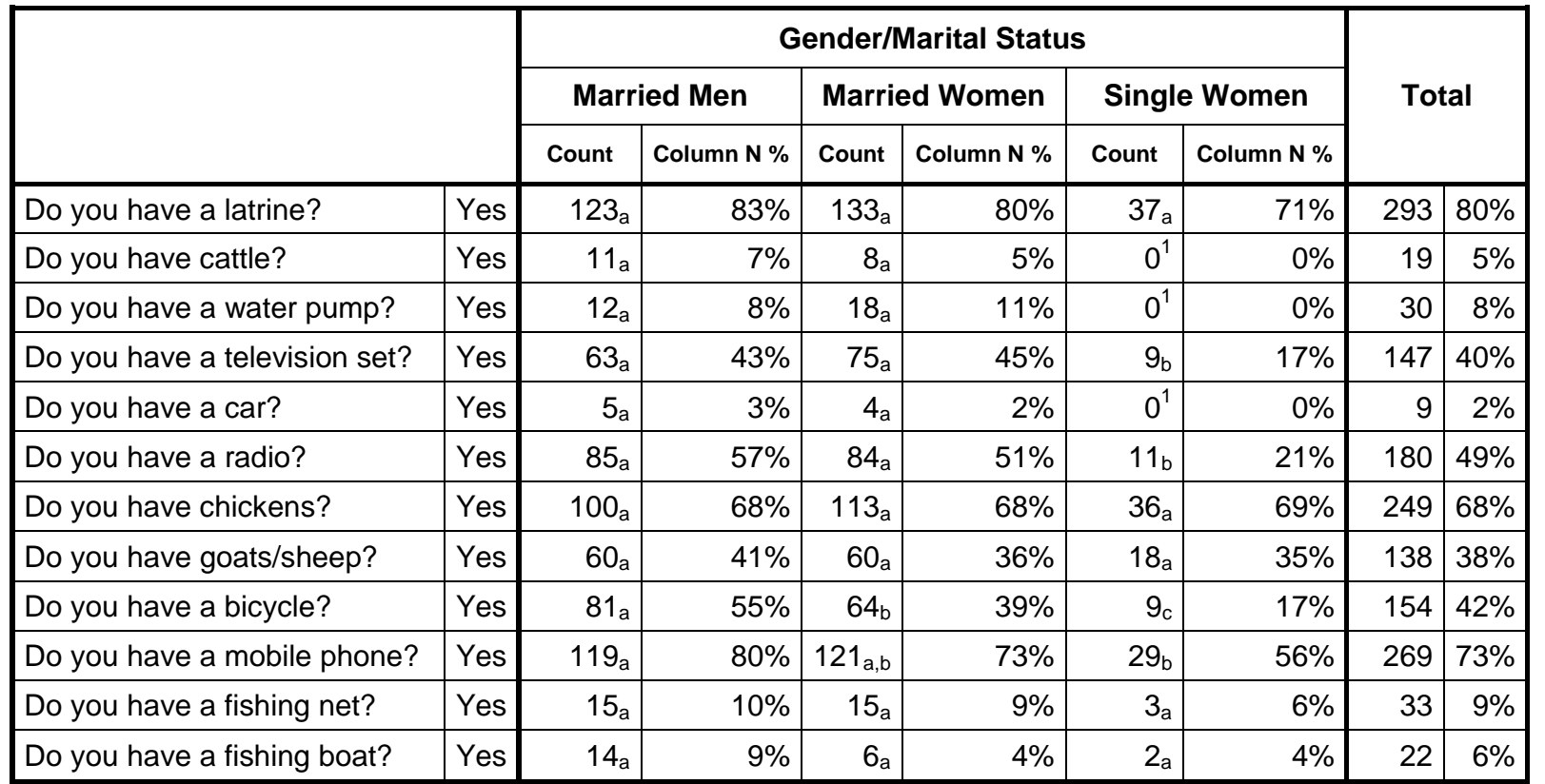

Note: Values in the same row and sub-table not sharing the same subscript are significantly different at $\mathrm{p}<.05$ in the two-sided test of equality for column proportions. Cells with no subscript are not included in the test. Tests assume equal variances. Tests are adiusted for all pairwise comparisons within a row of each innermost sub-table using the Bonferroni correction.

1. This category is not used in comparisons because its column proportion is equal to zero or one.

Assets were also analysed in relation to household size. In bigger households more latrines, cattle and goats/sheep were reported. This makes sense as bigger households have a larger number of people from which to pool together economic resources (either farming or working). However, bigger households must also divide the assets and share them with a larger group of people and these assets may not make such a significant impact in the lives of each household member.

Regarding house construction (Table 37), 26\% of the respondents' houses are made of mud-brick, $41 \%$ of Kiln brick and/or tin roof and $30 \%$ are made out of concrete. The only statistically significant difference was found in the poorest quality of housing (makeshift) with a higher percentage of single women $(12 \%)$ compared to married women (1\%). It is important to point out that the differences between married men and married women could be due to the fact that we don't have data from both spouses in every household. We also have data from more married women which could lead to differences in the results. 
Table 37. House construction by gender/marital status

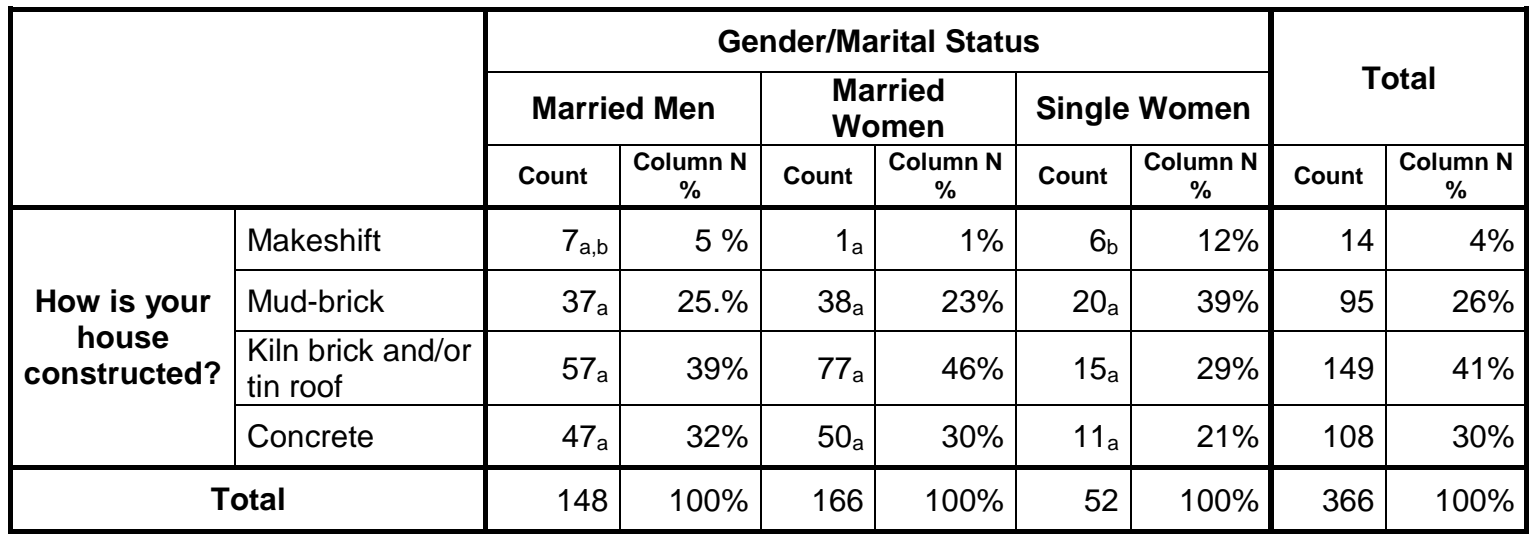

Note: Values in the same row and sub-table not sharing the same subscript are significantly different at $\mathrm{p}<.05$ in the twosided test of equality for column proportions. Cells with no subscript are not included in the test. Tests assume equal variances. Tests are adjusted for all pairwise comparisons within a row of each innermost sub-table using the Bonferroni correction.

Most households (61\%) have no access to electricity, $28 \%$ use a solar panel and $11 \%$ are connected to the grid (results shown in Table 38). Again significant differences can be seen between married women and single women, a higher percentage of single women (89\%) have no electricity source (compared to $52 \%$ of married women). These results, along with those from the previous table indicate that single women's living environments are more deprived than those of married women.

Table 38. Electricity source by gender/marital status

\begin{tabular}{|c|c|c|c|c|c|c|c|c|c|}
\hline & & \multicolumn{6}{|c|}{ Gender/Marital Status } & \multirow{2}{*}{\multicolumn{2}{|c|}{ Total }} \\
\hline & & \multicolumn{2}{|c|}{ Married Men } & \multicolumn{2}{|c|}{ Married Women } & \multicolumn{2}{|c|}{ Single Women } & & \\
\hline & & Count & Column N \% & Count & Column N \% & Count & Column N \% & Count & Column N \% \\
\hline \multirow{3}{*}{$\begin{array}{c}\text { What } \\
\text { electricity } \\
\text { source do you } \\
\text { use? }\end{array}$} & None & $94 a$ & $64 \%$ & $87 \mathrm{a}$ & $52 \%$ & $43 b$ & $83 \%$ & 224 & $61 \%$ \\
\hline & Solar panel & $39_{a, b}$ & $26 \%$ & $57 \mathrm{a}$ & $34 \%$ & $7 \mathrm{~b}$ & $14 \%$ & 103 & $28 \%$ \\
\hline & Grid & $15 \mathrm{a}$ & $10 \%$ & $22 a$ & $13 \%$ & $2 a$ & $4 \%$ & 39 & $11 \%$ \\
\hline \multicolumn{2}{|c|}{ Total } & 148 & $100 \%$ & 166 & $100 \%$ & 52 & $100 \%$ & 366 & $100 \%$ \\
\hline
\end{tabular}

Note: Values in the same row and sub-table not sharing the same subscript are significantly different at $p<.05$ in the twosided test of equality for column proportions. Cells with no subscript are not included in the test. Tests assume equal variances. Tests are adjusted for all pairwise comparisons within a row of each innermost sub-table using the Bonferroni correction.

In drinking water sources and cooking fuel, no statistically significant differences were found by gender/marital status. Table 39 shows that $93 \%$ of respondents use a borehole as a drinking water source. In addition, the results in Table 40 reveal that $90 \%$ of respondents use wood as cooking fuel, and only $7 \%$ use electricity for cooking. 
Table 39. Drinking water source by gender/marital status

\begin{tabular}{|c|c|c|c|c|c|c|c|c|c|}
\hline & & \multicolumn{6}{|c|}{ Gender/Marital Status } & \multirow{2}{*}{\multicolumn{2}{|c|}{ Total }} \\
\hline & & \multicolumn{2}{|c|}{ Married Men } & \multicolumn{2}{|c|}{ Married Women } & \multicolumn{2}{|c|}{ Single Women } & & \\
\hline & & Count & Column N \% & Count & Column $\mathbf{N} \%$ & Count & Column N \% & Count & Column N \% \\
\hline \multirow{2}{*}{$\begin{array}{l}\text { What drinking } \\
\text { water source } \\
\text { do you use? }\end{array}$} & River & 9 & $6 \%$ & 10 & $6 \%$ & 7 & $14 \%$ & 26 & $7 \%$ \\
\hline & Borehole & 139 & $94 \%$ & 155 & $94 \%$ & 45 & $87 \%$ & 339 & $93 \%$ \\
\hline \multicolumn{2}{|l|}{ Total } & 148 & $100 \%$ & 165 & $100 \%$ & 52 & $100 \%$ & 365 & $100 \%$ \\
\hline
\end{tabular}

Table 40. Cooking source by gender/marital status

\begin{tabular}{|c|c|c|c|c|c|c|c|c|c|}
\hline & & \multicolumn{6}{|c|}{ Gender/Marital Status } & \multirow{2}{*}{\multicolumn{2}{|c|}{ Total }} \\
\hline & & \multicolumn{2}{|c|}{ Married Men } & \multicolumn{2}{|c|}{ Married Women } & \multicolumn{2}{|c|}{ Single Women } & & \\
\hline & & Count & Column N \% & Count & Column N \% & Count & Column N \% & Count & Column N \% \\
\hline \multirow{3}{*}{$\begin{array}{c}\text { What cooking } \\
\text { source do you } \\
\text { use? }\end{array}$} & Wood & 132 & $89 \%$ & 145 & $87 \%$ & 51 & $98 \%$ & 328 & $90 \%$ \\
\hline & Charcoal & 6 & $4 \%$ & 5 & $3 \%$ & 1 & $2 \%$ & 12 & $3 \%$ \\
\hline & Electricity & 10 & $7 \%$ & 16 & $10 \%$ & 0 & $0 \%$ & 26 & $7 \%$ \\
\hline \multicolumn{2}{|l|}{ Total } & 148 & $100.0 \%$ & 166 & $100.0 \%$ & 52 & $100.0 \%$ & 366 & $100.0 \%$ \\
\hline
\end{tabular}

No statistically significant differences found

\subsection{Economic indicators}

In order to identify the economic status of the respondents, the main source of survival ${ }^{10}$ variable was changed in SPSS into a new variable to create economic categories/groups. This new variable divides participants into 5 groups according to economic status. Respondents in Group 1 face the greatest economic hardship and those in Group 5 are the most economically comfortable (it is an ordinal variable). The groups were created based on local consultation and fieldwork experience and the occupations were assigned to groups according to the following list:

\begin{tabular}{|l|l|l|l|l|}
\hline \multicolumn{1}{|c|}{ Group 1 } & \multicolumn{1}{|c|}{ Group 2 } & \multicolumn{1}{c|}{ Group 3 } & \multicolumn{1}{c|}{ Group 4 } & \multicolumn{1}{c|}{ Group 5 } \\
\hline Unemployed & Beer brewing & Farmers if 16-50 bags & Farmers who harvest & Nurse \\
Housewife & Piece work & of maize (more than & more than 61 bags of & ZAWA officer \\
Retired/too old to & Farmers if 5-15 & 750kgs and up to & maize (more than & Teacher \\
work & bags of maize & 2500kgs) & 2500kgs) & Other government \\
& (750kgs or less) & Petty Trading & Sale of own produce in & officer \\
& Craft work & Fishing & market/lodges & \\
& Artisan/blacksmith & Private job & Safari lodge worker & Driver \\
& & Guard & Shopkeeper & Business (mechanic/ \\
& & Commercial farm & skilled worker) & \\
& worker & Priest/pastor/bishop & \\
& & & &
\end{tabular}

\footnotetext{
${ }^{10}$ We also tried using occupation as a variable but, as it was shown in the previous section, housewives better indicate their economic source of income when asked about their source of survival.
} 
We also compared the main source of survival with the amount of maize harvested, and when there were discrepancies about which group an individual belonged to on the basis of these two measures he/she was placed in the economically better group. The logic for this was that some of the categories were very big, especially the lowest one, which we felt was probably artificially inflated by the number of housewives it contained. The maize harvested, thus, offered a way to discriminate better between the groups. For example, an artisan/blacksmith (Group 2) who also farmed $1500 \mathrm{~kg}$ of maize (Group 3) was placed in Group 3. These groups were created to demonstrate personal economic status. This means a housewife (Group 1) could have a husband who is a safari lodge worker (Group 4) and might have more economic comfort in her household, but at a personal level the source of income is not fully hers. As IWB is an individualised measure, it was important that this economic variable captured personal rather than household economic status. The combination of main source of survival and maize harvested gives us a proxy for income.

Table 41 shows the division of the sample between groups can be seen; Groups 1 and 2 together represent $53 \%$ of all the respondents (Group 2 is the biggest one including $37 \%$ of respondents). Thereafter each subsequent group has progressively fewer members, and Group 5 only has 18 respondents who represent $5 \%$ of the sample.

Table 41. Economic categories based on main source of survival

\begin{tabular}{|l|r|r|}
\hline \multicolumn{3}{|c|}{$\begin{array}{c}\text { Economic categories based on main } \\
\text { source of survival }\end{array}$} \\
\hline & Frequency & Percentage \\
\hline Group 1 ECMS & 60 & $16 \%$ \\
\hline Group 2 ECMS & 136 & $37 \%$ \\
\hline Group 3 ECMS & 98 & $26 \%$ \\
\hline Group 4 ECMS & 60 & $16 \%$ \\
\hline Group 5 ECMS & 18 & $5 \%$ \\
\hline Total & 370 & $100 \%$ \\
\hline
\end{tabular}

After creating the livelihood groups, we looked into other variables that could serve as proxies of wealth, rather than income. For this, we chose assets, selecting out those which seemed to correlate in general terms with the livelihood variable. We created an asset holding/asset deprivation index with the following variables: house made of concrete, being connected to the grid for electrical supply, using electricity as cooking fuel, having savings or assets and having a television. For each of these, respondents were assigned one point, which gave us 6 groups (from 0 to 5 points), and these groups were reorganised into 5 (joining the top 2). The distribution of respondents in these assets groups is portrayed in Table 42, and, as was the case with the economic groups, most respondents congregate in groups 1 and 2 ( $31 \%$ an $27 \%$ respectively), although there are slightly more people in middle to top groups than in the livelihood groups.

Table 42. Asset groups

\begin{tabular}{|c|r|r|}
\hline \multicolumn{3}{|c|}{ Asset groups } \\
\hline & Frequency & Percentage \\
\hline Group 1 Asset & 116 & $31 \%$ \\
\hline Group 2 Asset & 99 & $27 \%$ \\
\hline Group 3 Asset & 86 & $23 \%$ \\
\hline Group 4 Asset & 34 & $9 \%$ \\
\hline Group 5 Asset & 35 & $9 \%$ \\
\hline Total & 370 & $100 \%$ \\
\hline
\end{tabular}


The correlation between economic groups based on source of survival and asset groups is 0.329 , significant at the 0.01 level. To further explore the relationships between ways of categorising people, we compared the groups to each other (Table 43). The correlation is clear as people in lower livelihood groups tend to also be in the lower asset groups, although there are some exceptions to this general rule. While none of the respondents in Group 5 of the livelihoods category are in the lowest asset group, there are some people in the lowest livelihoods categories who are in the high asset groups. This could be due to several reasons. Assets are accrued by the household and probably reflect years of work that the current source of survival does not reflect. The assets have also probably been amassed by the family as a whole and not only by the respondent's source of income. Additionally, housewives' assets reflect a household level economic status rather than a personal one. We therefore have two sets of economic groups; one based on assets (proxy for wealth) and the other based on main source of survival (as proxy for income).

Table 43. Economic categories based on main source of survival by asset groups

\begin{tabular}{|c|c|c|c|c|c|c|c|c|c|c|c|c|c|}
\hline & \multicolumn{10}{|c|}{ Assets groups } & \multirow{2}{*}{\multicolumn{2}{|c|}{ Total }} \\
\hline & & \multicolumn{2}{|c|}{ Group 1 Asset } & \multicolumn{2}{|c|}{ Group 2 Asset } & \multicolumn{2}{|c|}{ Group 3 Asset } & \multicolumn{2}{|c|}{ Group 4 Asset } & \multicolumn{2}{|c|}{ Group 5 Asset } & & \\
\hline & & Count & $\begin{array}{c}\text { Column } \\
\mathbf{N} \%\end{array}$ & Count & $\begin{array}{c}\text { Column } \\
\mathbf{N} \%\end{array}$ & Count & $\begin{array}{c}\text { Column } \\
\mathbf{N} \%\end{array}$ & Count & $\begin{array}{c}\text { Column } \\
\mathbf{N} \%\end{array}$ & Count & $\begin{array}{c}\text { Column } \\
\mathrm{N} \%\end{array}$ & Count & $\begin{array}{c}\text { Column } \\
\mathbf{N} \%\end{array}$ \\
\hline \multirow{5}{*}{ 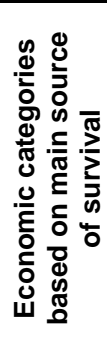 } & $\begin{array}{l}\text { Group } 1 \\
\text { ECMS }\end{array}$ & $21 \mathrm{a}$ & $18 \%$ & $17 \mathrm{a}$ & $15 \%$ & $11 \mathrm{a}$ & $13 \%$ & $8 a$ & $24 \%$ & $3 a$ & $9 \%$ & 60 & $16 \%$ \\
\hline & $\begin{array}{l}\text { Group } 2 \\
\text { ECMS }\end{array}$ & $55 a$ & $47 \%$ & $40_{a}$ & $40 \%$ & $30_{a, b}$ & $35 \%$ & $7 \mathrm{a}, \mathrm{b}$ & $21 \%$ & $4 b$ & $11 \%$ & 136 & $37 \%$ \\
\hline & $\begin{array}{l}\text { Group } 3 \\
\text { ECMS }\end{array}$ & $34_{a}$ & $29 \%$ & $25 a$ & $25 \%$ & $21_{a}$ & $24 \%$ & $8 a$ & $24 \%$ & $10_{a}$ & $29 \%$ & 98 & $26 \%$ \\
\hline & $\begin{array}{l}\text { Group } 4 \\
\text { ECMS }\end{array}$ & $6 a$ & $5 \%$ & $17_{b}$ & $17 \%$ & $19_{b}$ & $22 \%$ & $9 \mathrm{~b}$ & $26 \%$ & $7_{a, b}$ & $20 \%$ & 58 & $16 \%$ \\
\hline & $\begin{array}{l}\text { Group } 5 \\
\text { ECMS }\end{array}$ & $0^{1}$ & $0 \%$ & $0^{1}$ & $0 \%$ & $5 a$ & $6 \%$ & $2 a$ & $6 \%$ & $11_{b}$ & $31 \%$ & 18 & $5 \%$ \\
\hline \multicolumn{2}{|c|}{ Total } & 116 & $100 \%$ & 99 & $100 \%$ & 86 & $100 \%$ & 34 & $100 \%$ & 35 & $100 \%$ & 370 & $100 \%$ \\
\hline
\end{tabular}

Note: Values in the same row and sub-table not sharing the same subscript are significantly different at $p<.05$ in the two-sided test of equality for column proportions. Cells with no subscript are not included in the test. Tests assume equal variances. Tests are adjusted for all pairwise comparisons within a row of each innermost sub-table using the Bonferroni correction.

1. This category is not used in comparisons because its column proportion is equal to zero or one.

Respondents were also asked if they had been hungry over the past 12 months, 29\% say they have been hungry (for at least one month). As we did not have direct consumption questions, this variable serves as our proxy for consumption. The correlation between economic categories based on main source of survival and being hungry is significant and negative, meaning the more months someone has been hungry, the less likely they are to belong to the higher livelihood group. However the correlation is low $(-0.153)$. The correlation with assets groups is also negative and significant (implying also that the hungrier someone has been, the less likely that they belong to the group with more assets) but it is stronger $(-0.337)$.

With these economic indicators, we can now analyse how they relate to other variables.

\subsubsection{Economic indicators by gender/marital status}

The relation of these economic indicators to gender and marital status was assessed. When analysing them by economic categories based on source of survival (Table 44), the only statistically significant difference between women (married vs. single) arose in Group 1 as more married women (31\%) than single women (15\%) belonged to this group, and it is also very noteworthy that no married men are in Group $1 .{ }^{11}$ Additionally there is a significant difference in Group 4 as a high percentage of men (30\%) belong to this group while only $12 \%$ of married women and $4 \%$ of single women fall into the group.

\footnotetext{
${ }^{11}$ The statistical differences cannot be calculated when there are no cases in one category because of the type of analysis we are conducting.
} 
Finally, more married men (9\%) than married women (3\%) belong to Group 5, while no single women are in this group.

Table 44. Economic categories based on main source of survival by gender

\begin{tabular}{|c|c|c|c|c|c|c|c|c|c|}
\hline & & \multicolumn{6}{|c|}{ Gender/Marital Status } & \multirow{2}{*}{\multicolumn{2}{|c|}{ Total }} \\
\hline & & \multicolumn{2}{|c|}{ Married Men } & \multicolumn{2}{|c|}{ Married Women } & \multicolumn{2}{|c|}{ Single Women } & & \\
\hline & & Count & Column $\mathbf{N} \%$ & Count & Column N \% & Count & Column N \% & & \\
\hline \multirow{5}{*}{$\begin{array}{c}\text { Economic } \\
\text { categories } \\
\text { based on } \\
\text { main } \\
\text { source of } \\
\text { survival }\end{array}$} & Group 1 ECMS & $0^{1}$ & $0 \%$ & $52 a$ & $31 \%$ & $8 b$ & $15 \%$ & 60 & $16 \%$ \\
\hline & Group 2 ECMS & $53 a$ & $36 \%$ & $57 \mathrm{a}$ & $34 \%$ & $24 a$ & $46 \%$ & 134 & $37 \%$ \\
\hline & Group 3 ECMS & $38 a$ & $26 \%$ & $40_{a}$ & $24 \%$ & $18 \mathrm{a}$ & $35 \%$ & 96 & $26 \%$ \\
\hline & Group 4 ECMS & $44_{a}$ & $30 \%$ & $12_{b}$ & $7 \%$ & $2 \mathrm{~b}$ & $4 \%$ & 58 & $16 \%$ \\
\hline & Group 5 ECMS & $13_{a}$ & $9 \%$ & $5 b$ & $3 \%$ & $0^{1}$ & $0 \%$ & 18 & $5 \%$ \\
\hline \multicolumn{2}{|c|}{ Total } & 148 & $100 \%$ & 166 & $100 \%$ & 52 & $100 \%$ & 366 & $100 \%$ \\
\hline
\end{tabular}

Note: Values in the same row and sub-table not sharing the same subscript are significantly different at $p<.05$ in the twosided test of equality for column proportions. Cells with no subscript are not included in the test. Tests assume equal variances. Tests are adjusted for all pairwise comparisons within a row of each innermost sub-table using the Bonferroni 1. This category is not used in comparisons because its column proportion is equal to zero or one.

The differences in gender and marital status were also assessed in regards to the asset groups and the only purely gender statistically significant differences were found in Group 1; $22 \%$ of men belonged in this category while $38 \%$ of women did so (table not shown). When assessing the gender/marital status groups (Table 45) statistically significant differences were also found in Group 1 between single women $(56 \%)$ and both married men and women (32\% of married women and $22 \%$ of married men). This leads to the conclusion that single women have fewer assets and worse living conditions than married people.

Table 45. Asset groups by gender/marital status

\begin{tabular}{|c|c|c|c|c|c|c|c|c|c|}
\hline & & \multicolumn{6}{|c|}{ Gender/Marital Status } & \multirow{2}{*}{\multicolumn{2}{|c|}{ Total }} \\
\hline & & \multicolumn{2}{|c|}{ Married Men } & \multicolumn{2}{|c|}{ Married Women } & \multicolumn{2}{|c|}{ Single Women } & & \\
\hline & & Count & Column N \% & Count & Column N \% & Count & Column N \% & & \\
\hline \multirow{5}{*}{$\begin{array}{l}\text { Asset } \\
\text { groups }\end{array}$} & Group 1 Asset & $33 a$ & $22 \%$ & $53 a$ & $32 \%$ & $29_{b}$ & $56 \%$ & 115 & $31 \%$ \\
\hline & Group 2 Asset & $46_{a}$ & $31 \%$ & $39_{a}$ & $23 \%$ & $12 a$ & $23 \%$ & 97 & $27 \%$ \\
\hline & Group 3 Asset & $40_{a}$ & $27 \%$ & $37_{a}$ & $22 \%$ & $8 a$ & $15 \%$ & 85 & $23 \%$ \\
\hline & Group 4 Asset & $15 a$ & $10 \%$ & $18 \mathrm{a}$ & $11 \%$ & $1 \mathrm{a}$ & $2 \%$ & 34 & $9 \%$ \\
\hline & Group 5 Asset & $14 a$ & $9 \%$ & $19 \mathrm{a}$ & $11 \%$ & $2 a$ & $4 \%$ & 35 & $10 \%$ \\
\hline \multicolumn{2}{|r|}{ Total } & 148 & $100 \%$ & 166 & $100 \%$ & 52 & $100 \%$ & 366 & $100 \%$ \\
\hline
\end{tabular}

Note: Values in the same row and sub-table not sharing the same subscript are significantly different at $\mathrm{p}<.05$ in the two-sided test of equality for column proportions. Cells with no subscript are not included in the test. Tests assume equal variances. Tests are adjusted for all pairwise comparisons within a row of each innermost sub-table using the Bonferroni correction.

Being hungry (as a proxy for consumption) was also compared between the gender/marital status groups. As can be seen in Table 46, fewer married men reported being hungry than single women (with statistically significant differences). Regarding married women, the differences were not statistically significant enough to compare with either group, but the results show that they report hunger less than single women and more than married men. We also tested if there were gender differences in the extent of hunger without taking into account marital status. This showed $23 \%$ of men report being hungry while $35 \%$ of women do, with statistically significant differences. This could be due to inner household divisions of food or women's greater awareness of food shortages given that they are the ones who manage food distribution at the household level. 
Table 46. Hunger experienced by gender/marital status

\begin{tabular}{|c|c|c|c|c|c|c|c|c|c|}
\hline & & \multicolumn{6}{|c|}{ Gender/Marital Status } & \multirow{2}{*}{\multicolumn{2}{|c|}{ Total }} \\
\hline & & \multicolumn{2}{|c|}{ Married Men } & \multicolumn{2}{|c|}{ Married Women } & \multicolumn{2}{|c|}{ Single Women } & & \\
\hline & & Count & Column N \% & Count & Column N \% & Count & Column N \% & & \\
\hline \multirow{2}{*}{$\begin{array}{c}\text { Have you been hungry } \\
\text { over the past } 12 \\
\text { months? }\end{array}$} & Yes & $32_{a}$ & $22 \%$ & $53_{a, b}$ & $32 \%$ & $22_{b}$ & $43 \%$ & 107 & $29 \%$ \\
\hline & No & $115_{a}$ & $78 \%$ & $113_{a, b}$ & $68 \%$ & $29_{b}$ & $57 \%$ & 257 & $71 \%$ \\
\hline \multicolumn{2}{|l|}{ Total } & 147 & $100 \%$ & 166 & $100 \%$ & 51 & $100 \%$ & 364 & $100 \%$ \\
\hline
\end{tabular}

Note: Values in the same row and sub-table not sharing the same subscript are significantly different at $\mathrm{p}<.05$ in the twosided test of equality for column proportions. Cells with no subscript are not included in the test. Tests assume equal variances. Tests are adjusted for all pairwise comparisons within a row of each innermost sub-table using the Bonferroni correction.

This section shows that single women are, in general, in a more precarious condition; experiencing more hunger, having fewer assets and worse living conditions and less prosperous sources of survival. Furthermore, married women seem to be better off, in some of these indicators, than single women, but still in a worse position than married men. All of this illustrates the differentiated economic status and opportunities between married men, married women, and single women, and shows the advantage that married men enjoy.

\subsubsection{Economic indicators by education}

The correlation between school level reached and economic categories based on main source of survival is 0.451 (and significant at the 0.01 level). This is clear when analysing the differences between reaching different school levels and economic categories (Table 47) ${ }^{12}$. The majority of respondents in Group 1 have only reached some primary schooling (68\%) and none have gone to upper secondary or tertiary education. On the other hand $56 \%$ of respondents in Group 5 have attended tertiary education and no-one in this group has no education. The results show a clear association between higher educational levels and belonging to more prosperous livelihood groups.

Table 47. Economic categories based on main source of survival by gender /marital status

\begin{tabular}{|c|c|c|c|c|c|c|c|c|c|c|c|c|c|}
\hline & \multicolumn{10}{|c|}{ School level achieved } & \multirow{2}{*}{\multicolumn{2}{|c|}{ Total }} \\
\hline & & \multicolumn{2}{|c|}{ None } & \multicolumn{2}{|c|}{$\begin{array}{l}\text { Some primary } \\
\text { (kinder-7) }\end{array}$} & \multicolumn{2}{|c|}{$\begin{array}{c}\text { Some lower } \\
\text { secondary (8-9) }\end{array}$} & \multicolumn{2}{|c|}{$\begin{array}{c}\text { Some Upper } \\
\text { Secondary } \\
(10-12)\end{array}$} & \multicolumn{2}{|c|}{$\begin{array}{c}\text { Tertiary } \\
\text { education }\end{array}$} & & \\
\hline & & Count & $\begin{array}{c}\text { Row N } \\
\%\end{array}$ & Count & $\begin{array}{c}\text { Row N } \\
\%\end{array}$ & Count & Row N \% & Count & $\begin{array}{c}\text { Row N } \\
\%\end{array}$ & Count & $\begin{array}{l}\text { Row } \\
\mathrm{N} \%\end{array}$ & Count & $\begin{array}{c}\text { Row N } \\
\%\end{array}$ \\
\hline \multirow{5}{*}{ 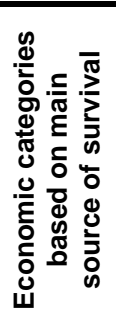 } & $\begin{array}{l}\text { Group } 1 \\
\text { ECMS }\end{array}$ & $13_{\mathrm{a}}$ & $22 \%$ & $41_{a}$ & $68 \%$ & $6 a$ & $10 \%$ & $0^{1}$ & $0 \%$ & $0^{1}$ & $0 \%$ & 60 & $100 \%$ \\
\hline & $\begin{array}{l}\text { Group } 2 \\
\text { ECMS }\end{array}$ & $25 a$ & $18 \%$ & $85 a$ & $63 \%$ & $20_{a, b}$ & $15 \%$ & $6 \mathrm{~b}$ & $4 \%$ & $0^{1}$ & $0 \%$ & 136 & $100 \%$ \\
\hline & $\begin{array}{l}\text { Group } 3 \\
\text { ECMS }\end{array}$ & $12 \mathrm{a}$ & $12 \%$ & $53 a$ & $54 \%$ & $18 \mathrm{a}$ & $18 \%$ & $15 \mathrm{a}$ & $15 \%$ & $0^{1}$ & $0 \%$ & 98 & $100 \%$ \\
\hline & $\begin{array}{l}\text { Group } 4 \\
\text { ECMS }\end{array}$ & $4 a$ & $7 \%$ & $29_{a, b}$ & $50 \%$ & $13_{a, b}$ & $22 \%$ & $11_{b}$ & $19 \%$ & $1_{a, b}$ & $2 \%$ & 58 & $100 \%$ \\
\hline & $\begin{array}{l}\text { Group } 5 \\
\text { ECMS }\end{array}$ & $0^{1}$ & $0.0 \%$ & $2 a$ & $11 \%$ & $2_{a, b}$ & $11 \%$ & $4 b$ & $22 \%$ & $10_{c}$ & $56 \%$ & 18 & $100 \%$ \\
\hline \multicolumn{2}{|l|}{ Total } & 54 & $15 \%$ & 210 & $57 \%$ & 59 & $16 \%$ & 36 & $10 \%$ & 11 & $3 . \%$ & 370 & $100 \%$ \\
\hline
\end{tabular}

Note: Values in the same row and sub-table not sharing the same subscript are significantly different at $p<.05$ in the two-sided test of equality for column proportions. Cells with no subscript are not included in the test. Tests assume equal variances. ${ }^{2}$

1. This category is not used in comparisons because its column proportion is equal to zero or one.

2. Tests are adjusted for all pairwise comparisons within a row of each innermost sub-table using the Bonferroni correction.

\footnotetext{
${ }^{12}$ The results in this table are presented a little differently than in the most of the report in order to better illustrate the educational differences. So, instead of having column percentages and totals, row percentages and totals by educational level reached will be shown.
} 
Similarly, the correlation between asset groups and school level reached is 0.326 and also significant (at the 0.01 level), albeit less strong. As before, the results in Table $48^{13}$ show that people with more education tend to be in better off groups, although this is not as clear as in the previous table. This could be because, as already mentioned, assets are acquired collectively whereas the main source of survival was recorded at an individual level. Thus, housewives and unemployed people could have a higher standard of living due to collectively pooled resources, and the impact of their education on their economic status is less significant.

Table 48. Assets groups by school level

\begin{tabular}{|c|c|c|c|c|c|c|c|c|c|c|c|c|c|}
\hline & \multicolumn{10}{|c|}{ School level achieved } & \multirow{2}{*}{\multicolumn{2}{|c|}{ Total }} \\
\hline & & \multicolumn{2}{|c|}{ None } & \multicolumn{2}{|c|}{$\begin{array}{c}\text { Some } \\
\text { primary } \\
\text { (kinder-7) }\end{array}$} & \multicolumn{2}{|c|}{$\begin{array}{c}\text { Some lower } \\
\text { secondary } \\
(8-9)\end{array}$} & \multicolumn{2}{|c|}{$\begin{array}{l}\text { Some Upper } \\
\text { Secondary } \\
(10-12)\end{array}$} & \multicolumn{2}{|c|}{$\begin{array}{c}\text { Tertiary } \\
\text { education }\end{array}$} & & \\
\hline & & Count & $\begin{array}{c}\text { Row N } \\
\% \\
\end{array}$ & Count & $\begin{array}{c}\text { Row N } \\
\%\end{array}$ & Count & $\begin{array}{c}\text { Row N } \\
\%\end{array}$ & Count & $\begin{array}{c}\text { Row N } \\
\%\end{array}$ & Count & $\begin{array}{c}\text { Row N } \\
\%\end{array}$ & Count & $\begin{array}{c}\text { Row N } \\
\%\end{array}$ \\
\hline \multirow{5}{*}{ 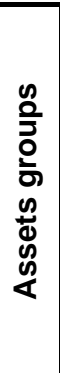 } & $\begin{array}{l}\text { Group } 1 \\
\text { Assets }\end{array}$ & $27 \mathrm{a}$ & $23 \%$ & $74_{a, b}$ & $64 \%$ & $11_{b, c}$ & $10 \%$ & $4 c$ & $3 \%$ & $0^{1}$ & $0 \%$ & 116 & $100 \%$ \\
\hline & $\begin{array}{l}\text { Group } 2 \\
\text { Assets }\end{array}$ & $10 a$ & $10 \%$ & $60_{a}$ & $61 \%$ & $18 \mathrm{a}$ & $18 \%$ & $10 \mathrm{a}$ & $10 \%$ & $1_{\mathrm{a}}$ & $1 \%$ & 99 & $100 \%$ \\
\hline & $\begin{array}{l}\text { Group } 3 \\
\text { Assets }\end{array}$ & $8 a$ & $9 \%$ & $47 \mathrm{a}$ & $55 \%$ & $17 \mathrm{a}$ & $20 \%$ & $13 \mathrm{a}$ & $15 \%$ & $1 \mathrm{a}$ & $1 \%$ & 86 & $100 \%$ \\
\hline & \begin{tabular}{|l|} 
Group 4 \\
Assets \\
\end{tabular} & $7 \mathrm{a}$ & $21 \%$ & $17 \mathrm{a}$ & $50 \%$ & $6 \mathrm{a}$ & $18 \%$ & $4 a$ & $12 \%$ & $0^{1}$ & $0 \%$ & 34 & $100 \%$ \\
\hline & $\begin{array}{l}\text { Group } 5 \\
\text { Assets }\end{array}$ & $2 a$ & $6 \%$ & $12_{a}$ & $34 \%$ & $7 \mathrm{a}$ & $20 \%$ & $5 a$ & $14 \%$ & $9 \mathrm{~b}$ & $26 \%$ & 35 & $100 \%$ \\
\hline \multicolumn{2}{|r|}{ Total } & 54 & $15 \%$ & 210 & $57 \%$ & 59 & $16 \%$ & 36 & $10 \%$ & 11 & $3 \%$ & 370 & $100 \%$ \\
\hline
\end{tabular}

Note: Values in the same row and sub-table not sharing the same subscript are significantly different at $\mathrm{p}<.05$ in the two-sided test of equality for column proportions. Cells with no subscript are not included in the test. Tests assume equal variances. Tests are adjusted for all pairwise comparisons within a row of each innermost sub-table using the Bonferroni correction.

1. This category is not used in comparisons because its column proportion is equal to zero or one.

$9 \%$ of people with higher education have been hungry over the past year compared to $34 \%$ of people with no education (no statistically significant differences were found). This indicates that there is a small association with higher education and not being hungry, but that it is not very strong or statistically significant. It also shows that regardless of their education, people may still experience hunger.

\subsubsection{Economic indicators and self-reported health status}

General state of heath was compared between economic categories based on main source of survival, asset groups, and being hungry in the past year. In every case the correlations were significant at the 0.01 level but not too strong; they were 0.296 with economic categories based on main sources of survival, 0.276 with asset groups. This tells us that there is a link between self-reported health status and the economic indicators, but the correlation is not that strong. The patterns among the groups were not so clearly seen and therefore not worth reporting here.

\subsubsection{Economic indicators by household size and type}

Household size and household type variables were also assessed in regards of the economic indicators. The number of people in the household (household size) has a small, positive and statistically significant correlation of 0.173 with economic categories based on main source of survival, and of 0.104 with asset groups, but it did not show any significant correlations with being hungry in the past year. When comparing differences with each house size group no statistically significant differences were found for being hungry or for the economic categories based on main source of survival. Some small differences were found when comparing household size with assets groups (results in Table 49), for example a higher percentage of respondents in households of 11 to 14 (23\%) are in Group 4 when compared with respondent of households from 1 to 4 ( $2 \%$ in group 4). Additionally

\footnotetext{
${ }^{13}$ The results in this table are presented as in the table before to better see the educational differences; instead of having column percentages and totals, row percentages and totals by educational level reached will be shown.
} 
a lower percentage of respondents in households of 8 to 10 are in Group 1 (22\%) than respondents in households of 1 to 4 (45\% are in Group 1).

Table 49. Asset groups by household size

\begin{tabular}{|c|c|c|c|c|c|c|c|c|c|c|c|}
\hline & \multicolumn{8}{|c|}{ Household size } & \multirow{2}{*}{\multicolumn{2}{|c|}{ Total }} \\
\hline & & \multicolumn{2}{|c|}{1 to 4} & \multicolumn{2}{|c|}{5 to 7} & \multicolumn{2}{|c|}{8 to 10} & \multicolumn{2}{|c|}{11 to 14} & & \\
\hline & & Count & $\begin{array}{l}\text { Column } \\
\mathrm{N} \%\end{array}$ & Count & $\begin{array}{c}\text { Column } \\
\mathrm{N} \%\end{array}$ & Count & $\begin{array}{l}\text { Column } \\
\mathrm{N} \%\end{array}$ & Count & $\begin{array}{l}\text { Column } \\
\mathrm{N} \%\end{array}$ & Count & $\begin{array}{c}\text { Column } \\
\mathrm{N} \%\end{array}$ \\
\hline \multirow{5}{*}{ 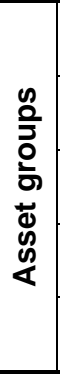 } & $\begin{array}{l}\text { Group } 1 \\
\text { Assets }\end{array}$ & $38 a$ & $45 \%$ & $50_{a, b}$ & $29 \%$ & $20 b$ & $22 \%$ & $8 a, b$ & $36 \%$ & 116 & $31 \%$ \\
\hline & $\begin{array}{l}\text { Group } 2 \\
\text { Assets }\end{array}$ & $17 \mathrm{a}$ & $20 \%$ & $47 \mathrm{a}$ & $27 \%$ & $32 \mathrm{a}$ & $35 \%$ & $3 a$ & $14 \%$ & 99 & $27 \%$ \\
\hline & \begin{tabular}{|l|} 
Group 3 \\
Assets
\end{tabular} & $22 a$ & $26 \%$ & $35 a$ & $20 \%$ & $23 a$ & $25 \%$ & $6 a$ & $27 \%$ & 86 & $23 \%$ \\
\hline & \begin{tabular}{|l|} 
Group 4 \\
Assets
\end{tabular} & $2 a$ & $2 \%$ & $21_{a, b}$ & $12 \%$ & $6 \mathrm{a}, \mathrm{b}$ & $7 \%$ & $5 b$ & $23 \%$ & 34 & $9 \%$ \\
\hline & $\begin{array}{l}\text { Group } 5 \\
\text { Assets }\end{array}$ & $5 a$ & $6 \%$ & $19_{a}$ & $11 \%$ & $11_{\mathrm{a}}$ & $12 \%$ & $0^{1}$ & $0 \%$ & 35 & $9 \%$ \\
\hline \multicolumn{2}{|r|}{ Total } & 84 & $100 \%$ & 172 & $100 \%$ & 92 & $100 \%$ & 22 & $100 \%$ & 370 & $100 \%$ \\
\hline
\end{tabular}

Note: Values in the same row and sub-table not sharing the same subscript are significantly different at $p<.05$ in the twosided test of equality for column proportions. Cells with no subscript are not included in the test. Tests assume equal 1. This category is not used in comparisons because its column proportion is equal to zero or one.

\subsubsection{Economic indicators by ethnicity}

Ethnicity was analysed for links to the main economic indicators and no differences were found among ethnic groups in being hungry over the past year. However, when analysing ethnicity by asset groups it was found that a higher percentage of Tongas (21\% out of the 29 respondents that are Tonga) belong to Group 5, additionally $67 \%$ of Bembas (out of the 12 respondents that are Bemba) are also in Group 5, while a lower percentage of Gobas (4\% out of the 237 Goba respondents) are in Group 5, and 32\% are in Group 1. This same pattern, Bembas and Tongas belonging to the better off groups while Gobas to the more deprived ones, is repeated when analysing economic categories based on main source of survival. These results indicate that in general Tongas and Bembas, as groups, have better assets and sources of income than Gobas. This reflects the fact that people of Tonga and Bemba ethnicity are likely to be in-migrating professionals, while most of the ordinary village people are Goba.

\section{Savings, help and loans}

\subsection{Savings}

Respondents were asked if they had savings or assets they could use in case of hard times, and more than half $(56 \%)$ responded positively. But when comparing savings between gender/marital status groups very clear (and statistically significant) differences arise between all groups, as $69 \%$ of married men say that they have savings, compared to $52 \%$ of married women and only $33 \%$ of single women. This means that women, and particularly single women, are more vulnerable to unforeseen economic hardships, as they lack assets and savings to fall back on in case of emergencies or changes in their life. 


\begin{tabular}{|c|c|c|c|c|c|c|c|c|c|}
\hline & & \multicolumn{6}{|c|}{ Gender/Marital Status } & \multirow{3}{*}{\multicolumn{2}{|c|}{ Total }} \\
\hline & & \multicolumn{2}{|c|}{ Married Men } & \multicolumn{2}{|c|}{$\begin{array}{l}\text { Married } \\
\text { Women }\end{array}$} & \multicolumn{2}{|c|}{ Single Women } & & \\
\hline & & Count & $\underset{\%}{\operatorname{Column} \mathbf{N}}$ & Count & $\begin{array}{c}\text { Column N } \\
\%\end{array}$ & Count & $\underset{\%}{\text { Column } \mathbf{N}}$ & & \\
\hline \multirow{2}{*}{$\begin{array}{c}\text { Do you have savings } \\
\text { or assets for hard } \\
\text { times? }\end{array}$} & No & $46 a$ & $31 \%$ & $80_{b}$ & $48 \%$ & $35_{c}$ & $67 \%$ & 161 & $44 \%$ \\
\hline & Yes & $102 a$ & $69 \%$ & $86_{b}$ & $52 \%$ & $17_{\mathrm{c}}$ & $33 \%$ & 205 & $56 \%$ \\
\hline \multicolumn{2}{|l|}{ Total } & 148 & $100 \%$ & 166 & $100 \%$ & 52 & $100 \%$ & 366 & $100 \%$ \\
\hline
\end{tabular}

Note: Values in the same row and sub-table not sharing the same subscript are significantly different at $p<.05$ in the two-sided test of equality for column proportions. Cells with no subscript are not included in the test. Tests assume equal variances. Tests are adjusted for all pairwise comparisons within a row of each innermost sub-table using the Bonferroni correction.

\section{$8.2 \quad$ Loans}

We asked respondents if they had taken any loans in the previous year, and only a small percentage (14\%) had done so. We explored differences between men and women and between gender/marital status but no statistically significant differences arose. The sources of the loans were primarily microfinance institutions (43\%) and NGOs (25\%), and no significant gender or marital status differences were found (table $52^{14}$ ).

Table 51. Sources of loans by gender/marital status

\begin{tabular}{|c|c|c|c|c|c|c|c|c|c|}
\hline & & \multicolumn{6}{|c|}{ Gender/Marital Status } & \multirow{2}{*}{\multicolumn{2}{|c|}{ Total }} \\
\hline & & \multicolumn{2}{|c|}{ Married Men } & \multicolumn{2}{|c|}{$\begin{array}{l}\text { Married } \\
\text { Women }\end{array}$} & \multicolumn{2}{|c|}{ Single Women } & & \\
\hline & & Count & $\underset{\%}{\operatorname{Column} \mathbf{N}}$ & Count & $\underset{\%}{\text { Column } \mathbf{N}}$ & Count & $\underset{\%}{\operatorname{Column} \mathbf{N}}$ & & \\
\hline Family & Yes & 0 & $0 \%$ & 0 & $0 \%$ & 0 & $0 \%$ & 0 & $0 \%$ \\
\hline Friends/neighbours & Yes & 0 & $0 \%$ & 1 & $4 \%$ & 0 & $0 \%$ & 1 & $2 \%$ \\
\hline Microfinance institution & Yes & 11 & $46 \%$ & 10 & $43 \%$ & 2 & $33 \%$ & 23 & $43 \%$ \\
\hline NGO & Yes & 3 & $13 \%$ & 8 & $35 \%$ & 2 & $33 \%$ & 13 & $25 \%$ \\
\hline Church & Yes & 0 & $0 \%$ & 0 & $0 \%$ & 0 & $0 \%$ & 0 & $0 \%$ \\
\hline Bank & Yes & 7 & $29 \%$ & 3 & $13 \%$ & 0 & $0 \%$ & 10 & $19 \%$ \\
\hline Other & Yes & 2 & $8 \%$ & 1 & $4 \%$ & 2 & $33 \%$ & 5 & $9 \%$ \\
\hline
\end{tabular}

Note: No significant differences were found

As $86 \%$ of the sample did not take a loan in the past year, the reasons for not taking a loan are important to analyse. In general the reply most respondents gave for not taking a loan was that despite needing one, they did not try to get it because they doubted they could pay it back $(49 \%)$. There are gender/marital status differences in this, as a lower percentage of married men $(40 \%)$ than married women (62\%) answered in this way. Additionally, $20 \%$ of respondents who did not get a loan had actually tried to get one but failed. This is in part due to a particular occurrence around the time of the study - a pre-election political campaign encouraged people to apply for a loan, but once the election had taken place no loans were in fact forthcoming. We analysed if there were differences in the reasons for not taking a loan by gender and marital status and there were significant differences between married men in comparison to single and married women. A higher percentage of married men (27\%) than married women (10\%) said that they needed a loan but knew they could not get it.

\footnotetext{
${ }^{14}$ This table is an amalgamation of several variables. Respondents were asked if they took a loan from each of these sources and so row totals are not pertinent as people could have taken a loan from more than one sources. For this reason the total column \% does not add to 100 .
} 
Table 52. Reasons for not taking a loan by gender/marital status

\begin{tabular}{|c|c|c|c|c|c|c|c|c|c|}
\hline & & \multicolumn{6}{|c|}{ Gender/Marital Status } & \multirow{2}{*}{\multicolumn{2}{|c|}{ Total }} \\
\hline & & \multicolumn{2}{|c|}{ Married Men } & \multicolumn{2}{|c|}{ Married Women } & \multicolumn{2}{|c|}{ Single Women } & & \\
\hline & & Count & $\begin{array}{c}\text { Column N } \\
\%\end{array}$ & Count & $\begin{array}{c}\text { Column N } \\
\%\end{array}$ & Count & $\begin{array}{c}\text { Column N } \\
\%\end{array}$ & & \\
\hline \multirow{4}{*}{$\begin{array}{c}\text { Why did you } \\
\text { not take a } \\
\text { loan? }\end{array}$} & Did not need one & $19_{a}$ & $16 \%$ & $19 \mathrm{a}$ & $13 \%$ & $4 a$ & $9 \%$ & 42 & $14 \%$ \\
\hline & $\begin{array}{l}\text { Needed one but knew } \\
\text { could not get it, so did }\end{array}$ & $33_{a}$ & $27 \%$ & $15_{b}$ & $10 \%$ & $6 a, b$ & $13 \%$ & 54 & $17 \%$ \\
\hline & $\begin{array}{l}\text { Needed one but doubted } \\
\text { we could pay it back, so }\end{array}$ & $49 a$ & $40 \%$ & $76_{a, b}$ & $53 \%$ & $28 b$ & $62 \%$ & 153 & $49 \%$ \\
\hline & $\begin{array}{l}\text { Needed one and tried } \\
\text { but could not get it }\end{array}$ & $21_{a}$ & $17 \%$ & $33_{a}$ & $23 \%$ & $7 \mathrm{a}$ & $16 \%$ & 61 & $20 \%$ \\
\hline & Total & 122 & $100 \%$ & 143 & $100 \%$ & 45 & $100 \%$ & 310 & $100 \%$ \\
\hline
\end{tabular}

Note: Values in the same row and sub-table not sharing the same subscript are significantly different at $p<.05$ in the two-sided test of equality for column proportions. Cells with no subscript are not included in the test. Tests assume equal variances. Tests are adjusted for all pairwise comparisons within a row of each innermost sub-table using the Bonferroni correction.

\subsection{Receipt of household help}

Apart from taking loans, we asked respondents if they had received any help in cash or in kind that had been important for meeting the household's needs (i.e. not just a cup of sugar or bowl of mealie meal) and $43 \%$ said that they had indeed received such help. No significant differences were found either by gender or marital status.

The majority of respondents that had received help, received it from their family (64\%), and secondly from their friends/neighbours (28\%), as it is shown in Table 53 . When analysing gender/marital status in regards to the sources of help, a significant difference arose between single women and married men and women, as $93 \%$ of single women said that the loans came from their family. This percentage is lower in married men (57\%) and married women (59\%). In contrast, only one single woman received help from her neighbours, while more than a third of married men and married women said that their friends and neighbours helped them. These results are consistent with the qualitative interviews which describe single women as relatively isolated, and mainly dependent on their family for support.

Table 53. Sources of help received by gender/marital status

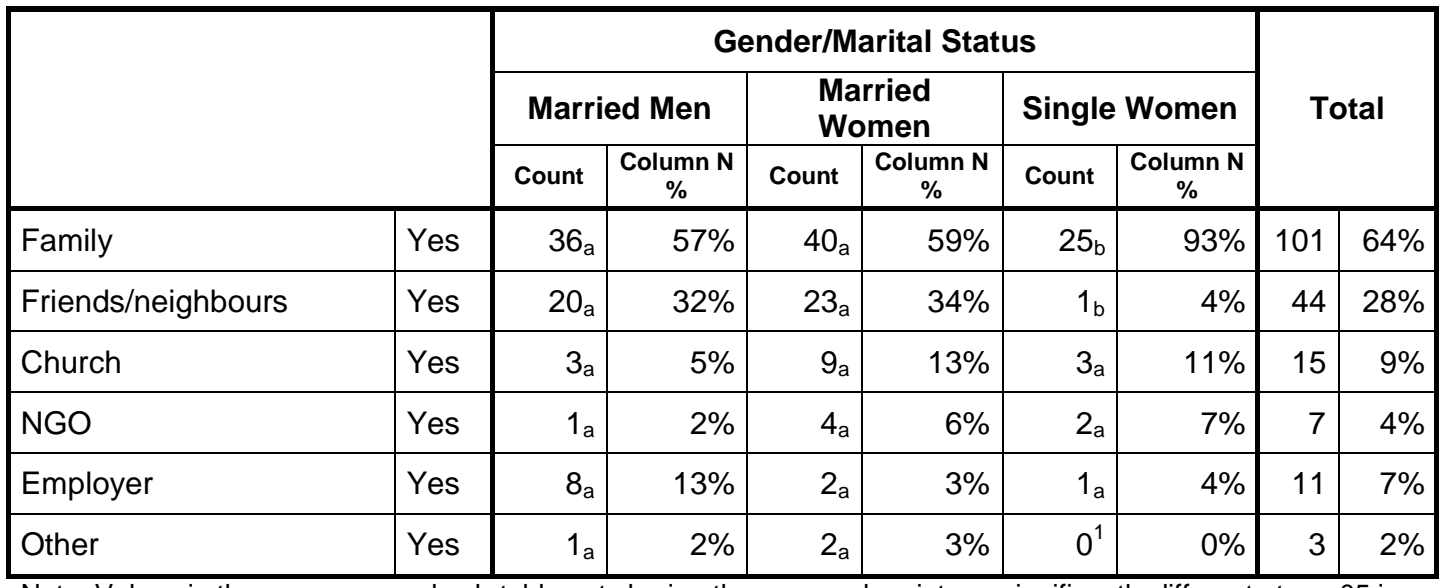

Note: Values in the same row and sub-table not sharing the same subscript are significantly different at $p<.05$ in the two-sided test of equality for column proportions. Cells with no subscript are not included in the test. Tests assume equal variances. Tests are adjusted for all pairwise comparisons within a row of each innermost sub-table using the Bonferroni correction. 
The primary purpose of this help (Table 54 ) was for household needs $(87 \%)$, followed by health needs $(12 \%)$ and education (10\%). No gender or marital status differences were found.

Table 54. Destination of help received by gender/marital status

\begin{tabular}{|c|c|c|c|c|c|c|c|c|c|}
\hline & & \multicolumn{6}{|c|}{ Gender/Marital Status } & \multirow{3}{*}{\multicolumn{2}{|c|}{ Total }} \\
\hline & & \multicolumn{2}{|c|}{ Married Men } & \multicolumn{2}{|c|}{$\begin{array}{l}\text { Married } \\
\text { Women }\end{array}$} & \multicolumn{2}{|c|}{ Single Women } & & \\
\hline & & Count & $\underset{\%}{\text { Column N }}$ & Count & $\underset{\%}{\text { Column N }}$ & Count & $\underset{\%}{\text { Column } \mathbf{N}}$ & & \\
\hline Education & Yes & 6 & $10 \%$ & 4 & $6 \%$ & 6 & $22 \%$ & 16 & $10 \%$ \\
\hline Health & Yes & 7 & $11 \%$ & 10 & $15 \%$ & 2 & $7 \%$ & 19 & $12 \%$ \\
\hline Household needs & Yes & 56 & $89 \%$ & 56 & $81 \%$ & 26 & $96 \%$ & 138 & $87 \%$ \\
\hline Business & Yes & 1 & $2 \%$ & 6 & $9 \%$ & 1 & $4 \%$ & 8 & $5 \%$ \\
\hline Marriage & Yes & 0 & $0 \%$ & 2 & $3 \%$ & 0 & $0 . \%$ & 2 & $1 \%$ \\
\hline Funeral & Yes & 2 & $3 \%$ & 2 & $3 \%$ & 1 & $4 \%$ & 5 & $3 \%$ \\
\hline Other things & Yes & 0 & $0 \%$ & 1 & $1 \%$ & 0 & $0 \%$ & 1 & $1 \%$ \\
\hline
\end{tabular}

${ }^{*}$ No significant differences found

\subsection{Helping others}

Helping other households in cash or kind was reported by $63 \%$ of respondents and there were statistically significant differences that stemmed from gender/marital status, as a statistically significant higher percentage of married men $(72 \%)$ than single women $(40 \%)$ report having given any help in the past 12 months (results in Table 55).

Table 55. Help given for household needs by gender/marital status

\begin{tabular}{|c|c|c|c|c|c|c|c|c|c|}
\hline & & \multicolumn{6}{|c|}{ Gender/Marital Status } & \multirow{3}{*}{\multicolumn{2}{|c|}{ Total }} \\
\hline & & \multicolumn{2}{|c|}{ Married Men } & \multicolumn{2}{|c|}{$\begin{array}{l}\text { Married } \\
\text { Women }\end{array}$} & \multicolumn{2}{|c|}{ Single Women } & & \\
\hline & & Count & $\begin{array}{c}\text { Column N } \\
\%\end{array}$ & Count & $\underset{\%}{\text { Column N }}$ & Count & $\underset{\%}{\text { Column N }}$ & & \\
\hline \multirow{2}{*}{$\begin{array}{l}\text { In the past } 12 \text { months have } \\
\text { you given any help in } \\
\text { cash/kind that has been } \\
\text { important for other } \\
\text { households' needs? }\end{array}$} & No & $41_{a}$ & $28 \%$ & $62 a$ & $37 \%$ & $31_{b}$ & $60 \%$ & 134 & $37 \%$ \\
\hline & Yes & $107 \mathrm{a}$ & $72 \%$ & $104 a$ & $63 \%$ & $21_{b}$ & $40 \%$ & 232 & $63 \%$ \\
\hline \multicolumn{2}{|l|}{ Total } & 148 & $100 \%$ & 166 & $100 \%$ & 52 & $100 \%$ & 366 & $100 \%$ \\
\hline
\end{tabular}

Note: Values in the same row and sub-table not sharing the same subscript are significantly different at $p<.05$ in the twosided test of equality for column proportions. Cells with no subscript are not included in the test. Tests assume equal variances. Tests are adjusted for all pairwise comparisons within a row of each innermost sub-table using the Bonferroni correction.

As was the case in help received, help was given mostly to family $(78 \%$ of those who gave help gave to family) and to friends or neighbours (49\% gave to friends and neighbours). The only statistically significant difference by gender/marital status arose in giving help to family - more married men (84\%) reported this than single women (52\%). Purely gender differences were also assessed and the only statistically significant difference between men and women was giving to church - more men (11\%) than women (3\%) reported doing so. 
Table 56. Destination of help given for household needs by gender/marital status

\begin{tabular}{|c|c|c|c|c|c|c|c|c|c|}
\hline & & \multicolumn{6}{|c|}{ Gender/Marital Status } & \multirow{2}{*}{\multicolumn{2}{|c|}{ Total }} \\
\hline & & \multicolumn{2}{|c|}{ Married Men } & \multicolumn{2}{|c|}{ Married Women } & \multicolumn{2}{|c|}{ Single Women } & & \\
\hline & & Count & $\underset{\%}{\text { Column N }}$ & Count & $\begin{array}{c}\text { Column } \mathbf{N} \\
\%\end{array}$ & Count & $\underset{\%}{\text { Column N }}$ & & \\
\hline Family & Yes & $90_{a}$ & $84 \%$ & $79_{a, b}$ & $76 \%$ & $11_{b}$ & $52 \%$ & 180 & $78 \%$ \\
\hline Friends/neighbours & Yes & $55 a$ & $51 \%$ & $48 a$ & $46 \%$ & $11_{\mathrm{a}}$ & $52 \%$ & 114 & $49 \%$ \\
\hline Church & Yes & $12_{a}$ & $11 \%$ & $3 a$ & $3 \%$ & $1_{a}$ & $5 \%$ & 16 & $7 \%$ \\
\hline Employee & Yes & $0^{1}$ & $0 \%$ & $0^{1}$ & $0 \%$ & $0^{1}$ & $0 \%$ & 0 & $0 \%$ \\
\hline Other & Yes & $0^{1}$ & $0 \%$ & $0^{1}$ & $0 \%$ & $0^{1}$ & $0 \%$ & 0 & $0 \%$ \\
\hline
\end{tabular}

Note: Values in the same row and sub-table not sharing the same subscript are significantly different at $p<.05$ in the two-sided test of equality for column proportions. Cells with no subscript are not included in the test. Tests assume equal variances. Tests are adjusted for all pairwise comparisons within a row of each innermost sub-table using the Bonferroni correction.

1. This category is not used in comparisons because its column proportion is equal to zero or one.

The motives for giving help (Table 57) were very similar to the description of help received by households, and most respondents say that they gave help to fulfil household needs $(82 \%)$ followed by health (14\%) and education ( $8 \%)$. No significant differences were found when making the analysis by gender/marital status but there is a purely gender difference; men do report giving more help for education (13\%) than women do (4\%). This reflects the fact that education being a bigger investment, men are in a better economic position (as shown in earlier analyses) to render this assistance.

Table 57. Motives of help given by gender/marital status

\begin{tabular}{|c|c|c|c|c|c|c|c|c|c|}
\hline & & \multicolumn{6}{|c|}{ Gender/Marital Status } & \multirow{2}{*}{\multicolumn{2}{|c|}{ Total }} \\
\hline & & \multicolumn{2}{|c|}{ Married Men } & \multicolumn{2}{|c|}{ Married Women } & \multicolumn{2}{|c|}{ Single Women } & & \\
\hline & & Count & $\underset{\%}{\text { Column N }}$ & Count & $\underset{\%}{\operatorname{Column} \mathbf{N}}$ & Count & $\underset{\%}{\text { Column }} \mathbf{N}$ & & \\
\hline Education & Yes & 13 & $12 \%$ & 4 & $4 \%$ & 1 & $5 \%$ & 18 & $8 \%$ \\
\hline Health & Yes & 16 & $15 \%$ & 14 & $13 \%$ & 2 & $10 \%$ & 32 & $14 \%$ \\
\hline Household needs & Yes & 87 & $81 \%$ & 86 & $83 \%$ & 18 & $86 \%$ & 191 & $82 \%$ \\
\hline Business & Yes & 5 & $5 \%$ & 1 & $1 \%$ & 0 & $0 \%$ & 6 & $3 \%$ \\
\hline Marriage & Yes & 2 & $2 \%$ & 4 & $4 \%$ & 1 & $5 \%$ & 7 & $3 \%$ \\
\hline Funeral & Yes & 9 & $8 \%$ & 5 & $5 \%$ & 0 & $0 \%$ & 14 & $6 \%$ \\
\hline Other things & Yes & 4 & $4 \%$ & 7 & $7 \%$ & 1 & $5 \%$ & 12 & $5 \%$ \\
\hline
\end{tabular}

Note: No significant differences found

Given these results in giving and receiving help, it can be said that single women are more receivers than givers of help, which could probably be linked to their, previously established, less affluent economic situation. As single women have fewer assets, worse living conditions and less prosperous sources of survival, it follows that they won't be able to give too much help to other households. Also, given the fact that single women are mainly receivers of help, it indicates that they have more limited social relationships than other groups. 


\section{Group membership}

We asked respondents if they belonged to any groups and $44 \%$ said they did. As no significant differences were found when making the analysis by gender/marital status (results shown in Table 58), we analysed gender differences (without marital status) and the results showed that more women (49\%) than men $(37 \%)$ report that they belong to groups.

Table 58. Group belonging by gender

\begin{tabular}{|c|c|c|c|c|c|c|c|c|c|}
\hline & & \multicolumn{6}{|c|}{ Gender/Marital Status } & \multirow{2}{*}{\multicolumn{2}{|c|}{ Total }} \\
\hline & & \multicolumn{2}{|c|}{ Married Men } & \multicolumn{2}{|c|}{$\begin{array}{l}\text { Married } \\
\text { Women }\end{array}$} & \multicolumn{2}{|c|}{$\begin{array}{l}\text { Single } \\
\text { Women }\end{array}$} & & \\
\hline & & Count & $\begin{array}{c}\text { Column } \\
\mathrm{N} \%\end{array}$ & Count & $\begin{array}{c}\text { Column } \\
\mathrm{N} \%\end{array}$ & Count & $\begin{array}{c}\text { Column } \\
\mathbf{N} \%\end{array}$ & & \\
\hline \multirow{2}{*}{$\begin{array}{c}\text { Do you belong to any } \\
\text { group? }\end{array}$} & No & 93 & $63 \%$ & 85 & $51 \%$ & 26 & $50 \%$ & 204 & $56 \%$ \\
\hline & Yes & 55 & $37 \%$ & 81 & $49 \%$ & 26 & $50 \%$ & 162 & $44 \%$ \\
\hline \multicolumn{2}{|l|}{ Total } & 148 & 100 & 166 & 100 & 52 & 100 & 366 & $100 \%$ \\
\hline
\end{tabular}

Note: No significant differences found

The majority of respondents who belonged to a group, belonged to a church based group (41\%). This was followed by village based groups (27\%) and government sponsored groups (21\%). Table 59 shows the results of specific group membership by gender/marital status; the statistically significant differences occur mainly between married men and married women. For example, more married women $(25 \%)$ than married men (7\%) report belonging to an NGO group. The same is true of a privately sponsored group to which more married women (19\%) than married men $(4 \%)$ belong. This reflects the fact that NGOs and private groups have almost exclusively targeted women through their interventions. On the other hand, more married men (36\%) belong to a government sponsored group, which are usually farming related, while only $12 \%$ of women do. The only statistically significant difference found with single women was in membership of a village-based group which more single women $(42 \%)$ than married women (17\%) are members of (the differences with married men are not statistically significant).

Table 59. Groups by gender/marital status

\begin{tabular}{|c|c|c|c|c|c|c|c|c|c|}
\hline & \multicolumn{6}{|c|}{ Gender/Marital Status } & \multirow{2}{*}{\multicolumn{2}{|c|}{ Total }} \\
\hline & & \multicolumn{2}{|c|}{ Married Men } & \multicolumn{2}{|c|}{$\begin{array}{l}\text { Married } \\
\text { Women }\end{array}$} & \multicolumn{2}{|c|}{ Single Women } & & \\
\hline & & Count & $\underset{\%}{\text { Column }} \mathbf{N}$ & Count & $\underset{\%}{\text { Column }} \mathbf{N}$ & Count & $\underset{\%}{\text { Column }} \mathbf{N}$ & Count & $\underset{\%}{\text { Column }} \mathbf{N}$ \\
\hline Village based group & Yes & $19_{a, b}$ & $35 \%$ & $14 \mathrm{a}$ & $17 \%$ & $11 b$ & $42 \%$ & 44 & $27 \%$ \\
\hline Church based group & Yes & $23_{a}$ & $42 \%$ & $37 \mathrm{a}$ & $46 \%$ & $7 \mathrm{a}$ & $27 \%$ & 67 & $41 \%$ \\
\hline NGO group & Yes & $4 a$ & $7 \%$ & $20_{b}$ & $25 \%$ & $4_{a, b}$ & $15 \%$ & 28 & $17 \%$ \\
\hline $\begin{array}{l}\text { Privately sponsored } \\
\text { group }\end{array}$ & Yes & $2 a$ & $4 \%$ & $15_{b}$ & $19 \%$ & $1_{a, b}$ & $4 \%$ & 18 & $11 \%$ \\
\hline $\begin{array}{l}\text { Government } \\
\text { sponsored group }\end{array}$ & Yes & $20 a$ & $36 \%$ & $10_{b}$ & $12 \%$ & $4_{a, b}$ & $15 \%$ & 34 & $21 \%$ \\
\hline Others & Yes & $4 a$ & $7 \%$ & $1_{a}$ & $1 \%$ & $1 \mathrm{a}$ & $4 \%$ & 6 & $4 \%$ \\
\hline
\end{tabular}

Note: Values in the same row and sub-table not sharing the same subscript are significantly different at $p<.05$ in the two-sided test of equality for column proportions. Cells with no subscript are not included in the test. Tests assume equal variances. Tests are adjusted for all pairwise comparisons within a row of each innermost sub-table using the Bonferroni correction. 


\section{Services}

\section{$10.1 \quad$ Health}

On average, respondents seem more satisfied than dissatisfied with the available health services (Table $60)$; more than half report being either somewhat satisfied $(31 \%)$ or very satisfied $(25 \%)$. This is somewhat surprising given the limited local provision. If the options are analysed numerically the results show that, on a scale from 1 to 5 , married men and married women on average score 3,4 and single women 3,7 (without any significant statistical differences between them). Nonetheless, respondents did express concern with particular issues with the health care services, and, the majority (73\%) are concerned with the lack of medicines (Table $61^{15}$ ). A further $48 \%$ are concerned with staffing issues and $38 \%$ with the accessibility or distance to the healthcare available. Distance and accessibility is something that more married women (48\%) than men (29\%) were concerned about.

Table 60. Satisfaction with available health services by gender/marital status

\begin{tabular}{|c|c|c|c|c|c|c|c|c|c|}
\hline & \multicolumn{6}{|c|}{ Gender/Marital Status } & \multirow{2}{*}{\multicolumn{2}{|c|}{ Total }} \\
\hline & & \multicolumn{2}{|c|}{ Married Men } & \multicolumn{2}{|c|}{ Married Women } & \multicolumn{2}{|c|}{ Single Women } & & \\
\hline & & Count & Column N \% & Count & Column $\mathbf{N} \%$ & Count & Column $\mathbf{N} \%$ & Count & Column N \% \\
\hline \multirow{5}{*}{$\begin{array}{c}\text { Overall, } \\
\text { how } \\
\text { satisfied } \\
\text { are you } \\
\text { with the } \\
\text { health care } \\
\text { available? }\end{array}$} & Very dissatisfied & $14 a$ & $10 \%$ & $15 \mathrm{a}$ & $9 \%$ & $6 a$ & $12 \%$ & 35 & $10 \%$ \\
\hline & Rather dissatisfied & $24 a, b$ & $16 \%$ & $40_{a}$ & $24 \%$ & $4 b$ & $8 \%$ & 68 & $19 \%$ \\
\hline & $\begin{array}{l}\text { Neither satisfied } \\
\text { nor dissatisfied }\end{array}$ & $25 a$ & $17 \%$ & $22 \mathrm{a}$ & $13 \%$ & $8 a$ & $15 \%$ & 55 & $15 \%$ \\
\hline & Somewhat satisfied & $54 a$ & $37 \%$ & $44 a$ & $27 \%$ & $16_{a}$ & $31 \%$ & 114 & $31 \%$ \\
\hline & Very satisfied & $29 a$ & $20 \%$ & $45 a$ & $27 \%$ & $18 \mathrm{a}$ & $35 \%$ & 92 & $25 \%$ \\
\hline \multicolumn{2}{|r|}{ Total } & 146 & $100 \%$ & 166 & $100 \%$ & 52 & $100 \%$ & 364 & $100 \%$ \\
\hline
\end{tabular}

Note: Values in the same row and sub-table not sharing the same subscript are significantly different at $p<.05$ in the twosided test of equality for column proportions. Cells with no subscript are not included in the test. Tests assume equal variances. Tests are adjusted for all pairwise comparisons within a row of each innermost sub-table using the Bonferroni correction.

Table 61. Main health concerns by gender/marital status

\begin{tabular}{|c|c|c|c|c|c|c|c|c|c|}
\hline & & \multicolumn{8}{|c|}{ Gender/Marital Status } \\
\hline & & \multicolumn{2}{|c|}{ Married Men } & \multicolumn{2}{|c|}{$\begin{array}{l}\text { Married } \\
\text { Women }\end{array}$} & \multicolumn{2}{|c|}{$\begin{array}{l}\text { Single } \\
\text { Women }\end{array}$} & \multicolumn{2}{|c|}{ Subtotal } \\
\hline & & Count & $\begin{array}{l}\text { Column } \\
\mathrm{N} \%\end{array}$ & Count & $\begin{array}{l}\text { Column } \\
\mathrm{N} \%\end{array}$ & Count & $\begin{array}{l}\text { Column } \\
\mathrm{N} \%\end{array}$ & Count & $\begin{array}{l}\text { Column } \\
\mathrm{N} \%\end{array}$ \\
\hline $\begin{array}{l}\text { Are you concerned with the } \\
\text { distance/accessibility of the health } \\
\text { care available? }\end{array}$ & Yes & $43_{a}$ & $29 \%$ & $78_{b}$ & $48 \%$ & $16_{a, b}$ & $32 \%$ & 137 & $38 \%$ \\
\hline $\begin{array}{l}\text { Are you concerned with the cost of } \\
\text { the health care available? }\end{array}$ & Yes & $16 \mathrm{a}$ & $11 \%$ & $11 \mathrm{a}$ & $7 \%$ & $5 a$ & $10 \%$ & 32 & $9 \%$ \\
\hline $\begin{array}{l}\text { Are you concerned with the lack of } \\
\text { medicines? }\end{array}$ & Yes & $112 \mathrm{a}$ & $76 \%$ & $120_{a}$ & $74 \%$ & $30_{a}$ & $60 \%$ & 262 & $73 \%$ \\
\hline $\begin{array}{l}\text { Are you concerned with staff issues } \\
\text { of the health care available? }\end{array}$ & Yes & $72 \mathrm{a}$ & $49 \%$ & $79_{a}$ & $49 \%$ & $23_{a}$ & $46 \%$ & 174 & $48 \%$ \\
\hline $\begin{array}{l}\text { Are you concerned with other issues } \\
\text { related to the health care available? }\end{array}$ & Yes & $14 a$ & $10 \%$ & $8 a$ & $5 \%$ & $4 \mathrm{a}$ & $8 \%$ & 26 & $7 \%$ \\
\hline
\end{tabular}

Note: Values in the same row and sub-table not sharing the same subscript are significantly different at $p<.05$ in the two-sided test of equality for column proportions. Cells with no subscript are not included in the test. Tests assume equal variances.

\footnotetext{
${ }^{15}$ This table is an amalgamation of several variables. Respondents were asked if they were concerned with each of these aspects of the health care available and so row totals are not pertinent, as people could have visited more than one. In order to make reading easier, the count and percentages of respondents that said that they were not concerned with a particular issue were set aside. For that reason the total column \% does not add up to 100 .
} 


\section{$10.2 \quad$ Education}

The results in Table 62 show that on average respondents seem more satisfied than dissatisfied with the education available to the children in their families; more than half report being either somewhat satisfied $(33 \%)$ or very satisfied $(23 \%)$. If the options are analysed numerically the results show that, on a scale from 1 to 5 , married men, married women and single women on average score 3,5 and (without any significant statistical differences between them). Nonetheless the main concern regarding education is that teachers are either not there or are not good (45\% of those who stated a concern). All the other issues were stated by around a quarter of respondents who expressed concerns, as the results in Table $63^{16}$ show. No statistically significant differences were found by gender/marital status in either the satisfaction with available education or the educational concerns raised.

Table 62. Satisfaction with available education by gender/marital status

\begin{tabular}{|c|c|c|c|c|c|c|c|c|c|}
\hline & & \multicolumn{6}{|c|}{ Gender/Marital Status } & \multirow{2}{*}{\multicolumn{2}{|c|}{ Total }} \\
\hline & & \multicolumn{2}{|c|}{ Married Men } & \multicolumn{2}{|c|}{$\begin{array}{l}\text { Married } \\
\text { Women }\end{array}$} & \multicolumn{2}{|c|}{ Single Women } & & \\
\hline & & Count & \begin{tabular}{|c|c|} 
Column N N \\
$\%$
\end{tabular} & Count & \begin{tabular}{|c|c|} 
Column N N \\
$\%$
\end{tabular} & Count & \begin{tabular}{|c|}
$\begin{array}{c}\text { Column N N } \\
\%\end{array}$ \\
\end{tabular} & Count & $\begin{array}{c}\text { Column N } \\
\%\end{array}$ \\
\hline \multirow{5}{*}{$\begin{array}{l}\text { Overall, how } \\
\text { satisfied are } \\
\text { you with the } \\
\text { education } \\
\text { available to } \\
\text { children in } \\
\text { your family? }\end{array}$} & Very dissatisfied & 11 & $7 \%$ & 12 & $7 \%$ & 4 & $8 \%$ & 27 & $7 \%$ \\
\hline & $\begin{array}{l}\text { Rather } \\
\text { dissatisfied }\end{array}$ & 21 & $14 \%$ & 31 & $19 \%$ & 10 & $19 \%$ & 62 & $17 \%$ \\
\hline & $\begin{array}{l}\text { Neither satisfied } \\
\text { nor dissatisfied }\end{array}$ & 34 & $23 \%$ & 28 & $17 \%$ & 12 & $23 \%$ & 74 & $20 \%$ \\
\hline & $\begin{array}{l}\text { Somewhat } \\
\text { satisfied }\end{array}$ & 50 & $34 \%$ & 59 & $36 \%$ & 10 & $19 \%$ & 119 & $33 \%$ \\
\hline & Very satisfied & 31 & $21 \%$ & 36 & $22 \%$ & 16 & $31 \%$ & 83 & $23 \%$ \\
\hline \multicolumn{2}{|c|}{ Total } & 147 & $100 \%$ & 166 & $100 \%$ & 52 & $100 \%$ & 365 & $100 \%$ \\
\hline
\end{tabular}

No significant differences found

Table 63. Main educational concerns by gender/marital status

\begin{tabular}{|c|c|c|c|c|c|c|c|c|c|}
\hline & & \multicolumn{6}{|c|}{ Gender/Marital Status } & \multirow{2}{*}{\multicolumn{2}{|c|}{ Subtotal }} \\
\hline & & \multicolumn{2}{|c|}{ Married Men } & \multicolumn{2}{|c|}{$\begin{array}{l}\text { Married } \\
\text { Women }\end{array}$} & \multicolumn{2}{|c|}{ Single Women } & & \\
\hline & & Count & $\underset{\%}{\text { Column N }}$ & Count & $\begin{array}{c}\text { Column N } \\
\%\end{array}$ & Count & $\underset{\%}{\text { Column N }}$ & Count & $\underset{\%}{\text { Column } \mathbf{N}}$ \\
\hline $\begin{array}{l}\text { Are you concerned with the } \\
\text { distance/accessibility of the } \\
\text { available education? }\end{array}$ & Yes & 26 & $18 \%$ & 40 & $25 \%$ & 8 & $16 \%$ & 74 & $21 \%$ \\
\hline $\begin{array}{l}\text { Are you concerned with the } \\
\text { cost of the available } \\
\text { education? }\end{array}$ & Yes & 34 & $23 \%$ & 25 & $15 \%$ & 5 & $10 \%$ & 64 & $18 \%$ \\
\hline $\begin{array}{l}\text { Are you concerned that the } \\
\text { teachers are not there/not } \\
\text { good? }\end{array}$ & Yes & 69 & $48 \%$ & 75 & $47 \%$ & 17 & $33 \%$ & 161 & $45 \%$ \\
\hline $\begin{array}{l}\text { Are you concerned with the } \\
\text { teachers' behaviour } \\
\text { (including violence)? }\end{array}$ & Yes & 33 & $23 \%$ & 36 & $23 \%$ & 10 & $20 \%$ & 79 & $22 \%$ \\
\hline $\begin{array}{l}\text { Are you concerned with } \\
\text { other issues related to } \\
\text { education? }\end{array}$ & Yes & 34 & $23 \%$ & 33 & $20 \%$ & 6 & $12 \%$ & 73 & $20 \%$ \\
\hline
\end{tabular}

No significant differences found

\footnotetext{
${ }^{16}$ This table is an amalgamation of several variables. Respondents were asked if they were concerned with each of these aspects of the education available and so row totals are not pertinent, as people could have visited more than one. In order to make reading easier, the count and percentages of respondents that said that they were not concerned with a particular issue, were set aside. For that reason, the total column \% does not add up to 100.
} 


\subsection{Relief food}

Due to a serious drought that affected the region (meaning that people were not able to harvest the usual amount of maize), the government decided to give out relief food to everybody. This generally involved the allocation of one bag of maize per household, though a few households were given two. The vast majority of respondents (96\%) had received the relief food in the past 12 months, and the average amount of bags received was 1.35. The amount received was not sufficient in $90 \%$ of cases. Additionally, most people (78\%) stated that they received it too late, only $22 \%$ said that they got the relief food at the right time. These results indicate that the relief food program did reach a vast number of people in the region, but that the amount of food and timeliness of it did not fulfil their needs. No gender or marital status differences were found in any of the previous analyses.

\section{Developments in Chiawa}

At the time that the Round 2 fieldwork was underway, Chiawa was alive with talk of new developments in the pipeline. These include a new major road, new safari lodges, a new hotel and (at some distance) a new copper mine. Due to the potential impact on people's lives and the community in general, respondents were asked if they had heard about these developments, and $96 \%$ responded that they had. Interestingly a slightly smaller percentage of married women $(93 \%)$ than married men $(99 \%)$ had heard about them (results shown in Table 64), which could reflect less participation of married women in community affairs.

Table 64. Knowledge of new developments by gender/ marital status

\begin{tabular}{|c|c|c|c|c|c|c|c|c|c|}
\hline & & \multicolumn{6}{|c|}{ Gender/Marital Status } & \multirow{2}{*}{\multicolumn{2}{|c|}{ Total }} \\
\hline & & \multicolumn{2}{|c|}{ Married Men } & \multicolumn{2}{|c|}{$\begin{array}{l}\text { Married } \\
\text { Women }\end{array}$} & \multicolumn{2}{|c|}{ Single Women } & & \\
\hline & & Count & $\begin{array}{c}\text { Column N } \\
\%\end{array}$ & Count & $\begin{array}{c}\text { Column N } \\
\%\end{array}$ & Count & $\begin{array}{c}\text { Column N } \\
\%\end{array}$ & Count & $\begin{array}{c}\text { Column N } \\
\%\end{array}$ \\
\hline $\begin{array}{l}\text { Have you heard of the new } \\
\text { developments planned that will } \\
\text { affect the lives of people in } \\
\text { Chiawa? }\end{array}$ & Yes & $145 a$ & $99 \%$ & $153_{b}$ & $93 \%$ & $48_{a, b}$ & $96 \%$ & 346 & $96 \%$ \\
\hline
\end{tabular}

Note: Values in the same row and sub-table not sharing the same subscript are significantly different at $p<.05$ in the two-sided test of equality for column proportions. Cells with no subscript are not included in the test. Tests assume equal variances. Tests are adjusted for all pairwise comparisons within a row of each innermost sub-table using the Bonferroni correction.

Levels of satisfaction with how decisions regarding these new developments are currently being made are rather divided, but there is a tendency to evaluate this negatively. $30 \%$ say they are very dissatisfied with the decision-making process while only $12 \%$ report being very satisfied with it (Table 65). If these results are analysed numerically (on a scale of 1 to 5 ), it can be seen that on average married men and married women score 2,7 and single women 2,2 (without any statistically significant differences). Given the relatively positive rating of education and health facilities reported above, despite the fact that provision of these is rather limited, these figures suggest a rather high degree of dissatisfaction amongst the Chiawa people with the development related decision-making. The analysis did not show any gender or marital status differences that were statistically significant. 


\begin{tabular}{|c|c|c|c|c|c|c|c|c|c|}
\hline & & \multicolumn{6}{|c|}{ Gender/Marital Status } & \multirow{2}{*}{\multicolumn{2}{|c|}{ Total }} \\
\hline & & \multicolumn{2}{|c|}{ Married Men } & \multicolumn{2}{|c|}{$\begin{array}{l}\text { Married } \\
\text { Women }\end{array}$} & \multicolumn{2}{|c|}{ Single Women } & & \\
\hline & & Count & $\begin{array}{c}\text { Column N } \\
\%\end{array}$ & Count & \begin{tabular}{|c|}
$\begin{array}{c}\text { Column N } \\
\%\end{array}$ \\
\end{tabular} & Count & \begin{tabular}{|c|} 
Column N \\
$\%$
\end{tabular} & Count & $\begin{array}{c}\text { Column N } \\
\% \\
\end{array}$ \\
\hline \multirow{5}{*}{$\begin{array}{c}\text { How satisfied are } \\
\text { you with the way } \\
\text { decisions about } \\
\text { such things are } \\
\text { made? }\end{array}$} & Very dissatisfied & 45 & $31 \%$ & 41 & $27 \%$ & 18 & $37 \%$ & 104 & $30 \%$ \\
\hline & $\begin{array}{l}\text { Rather } \\
\text { dissatisfied }\end{array}$ & 26 & $18 \%$ & 23 & $15 \%$ & 8 & $16 \%$ & 57 & $16 \%$ \\
\hline & $\begin{array}{l}\text { Neither satisfied } \\
\text { nor dissatisfied }\end{array}$ & 30 & $21 \%$ & 45 & $29 \%$ & 17 & $35 \%$ & 92 & $27 \%$ \\
\hline & $\begin{array}{l}\text { Somewhat } \\
\text { satisfied }\end{array}$ & 21 & $14 \%$ & 26 & $17 \%$ & 5 & $10 \%$ & 52 & $15 \%$ \\
\hline & Very satisfied & 23 & $16 \%$ & 18 & $12 \%$ & 1 & $2 \%$ & 42 & $12 \%$ \\
\hline \multicolumn{2}{|c|}{ Total } & 145 & $100 \%$ & 153 & $100 \%$ & 49 & $100 \%$ & 347 & $100 \%$ \\
\hline
\end{tabular}

No significant differences found

\section{Inner Wellbeing}

Inner wellbeing (IWB) expresses what people feel and think they are able to do and be. In this section, we report on people's responses to our inner wellbeing questions which reflect seven distinct, yet related domains: economic confidence, agency and participation, social connections, close relationships, competence and self-worth, physical and mental health and values and meaning.

In order to analyse the inner wellbeing results and compare them to the other variables, we calculated the average score each participant had for each domain and their inner wellbeing average scores. To calculate the scores for each domain, we added the scores respondents had in each question (of the domain) and then divided it by the number of questions in that domain. ${ }^{17}$ To calculate the inner wellbeing score, we added the scores we had calculated for the domains and then divided by 7 (the number of domains).

All the domains have a strong (above 0.650) and significant correlation (at 0.01 level) with the inner wellbeing average, with the exception of close connections which has a 0.569 correlation (but also significant at 0.01) level. Furthermore the domains correlate with each other (also significant at 0.01 level); the lowest correlation is between economic wellbeing and close relationships at 0.215 , and the highest is between competence and self-worth with agency and participation at 0.513 .

\subsection{Subjective economic assessments and general happiness}

Before analysing the inner wellbeing results, we first considered three more mainstream questions to get a sense of how individuals assessed their lives. In the first place, we asked respondents how they would say they are doing economically considering the last twelve months, giving their answers on a scale from 1 (doing very badly) to 5 (doing very well). Table 64 shows the scores for personal economic assessment for each of the gender/marital status groups, and the results show that on average people feel they are just managing ( 3 in the survey) but there are statistically significant differences between married men, with an average of 3 , and single women, with an average of 2.5. Single women on average lean more towards doing somewhat badly ( 2 in the survey) than married men who are just managing.

\footnotetext{
17 We used every item in every domain except for one item in each of agency and participation, social connections and close relationships and values and meaning. In the first three of these domains the excluded item reflected a negative or counter factor (e.g. social hostility) which was therefore conceptually distinct from the other five items.
} 
This question was correlated with every inner wellbeing domain (Table 67) and it has the highest correlation with economic wellbeing at 0.403 and the lowest with close relationships at 0.133 , and correlates also with inner wellbeing average at 0.331 . All correlations were significant at the 0.01 level, except close relationships which was significant at 0.05 .

Table 66. Personal economic assessment by gender/marital status

\begin{tabular}{|l|r|c|c|c|}
\hline \multirow{2}{*}{} & \multicolumn{3}{|c|}{ Gender/Marital Status } & \multirow{2}{*}{ Total } \\
\cline { 2 - 5 } & $\begin{array}{c}\text { Married } \\
\text { Men }\end{array}$ & $\begin{array}{c}\text { Married } \\
\text { Women }\end{array}$ & $\begin{array}{c}\text { Single } \\
\text { Women }\end{array}$ & \\
\cline { 2 - 5 } & Mean & Mean & Mean & Mean \\
\hline $\begin{array}{c}\text { Considering the last twelve months, how } \\
\text { would you say you are doing economically? }\end{array}$ & $3.0_{\mathrm{a}}$ & $2.8_{\mathrm{a}, \mathrm{b}}$ & $2.5_{\mathrm{b}}$ & 2.9 \\
\hline
\end{tabular}

Note: Values in the same row and sub-table not sharing the same subscript are significantly different at $p<.05$ in the two-sided test of equality for column means. Cells with no subscript are not included in the test. Tests assume equal variances. Tests are adjusted for all pairwise comparisons within a row of each innermost sub-table using the Bonferroni correction.

Table 67. Correlation personal economic assessment with well-being domains

\begin{tabular}{|c|c|c|}
\hline \multicolumn{3}{|c|}{ Correlations } \\
\hline & & $\begin{array}{l}\text { Considering the last twelve } \\
\text { months, how would you say } \\
\text { you are doing economically? }\end{array}$ \\
\hline \multirow{2}{*}{ Economic wellbeing } & Pearson Correlation &, $403^{* \star}$ \\
\hline & Sig. (2-tailed) & .000 \\
\hline \multirow{2}{*}{$\begin{array}{l}\text { Agency and } \\
\text { participation }\end{array}$} & Pearson Correlation &, $136^{\star \star}$ \\
\hline & Sig. (2-tailed) & .009 \\
\hline \multirow{2}{*}{ Social Connections } & Pearson Correlation &, $239^{* *}$ \\
\hline & Sig. (2-tailed) & .000 \\
\hline \multirow{2}{*}{ Close Relationships } & Pearson Correlation &, $133^{*}$ \\
\hline & Sig. (2-tailed) & .010 \\
\hline \multirow{2}{*}{$\begin{array}{l}\text { Physical and mental } \\
\text { health }\end{array}$} & Pearson Correlation &, $217^{* *}$ \\
\hline & Sig. (2-tailed) & .000 \\
\hline \multirow{2}{*}{$\begin{array}{l}\text { Competence and self } \\
\text { worth }\end{array}$} & Pearson Correlation &, $256^{* *}$ \\
\hline & Sig. (2-tailed) & .000 \\
\hline \multirow{2}{*}{ Values and meaning } & Pearson Correlation & ,238* \\
\hline & Sig. (2-tailed) & .000 \\
\hline \multirow{2}{*}{$\begin{array}{c}\text { Inner wellbeing } \\
\text { average }\end{array}$} & Pearson Correlation &, $331^{* *}$ \\
\hline & Sig. (2-tailed) & .000 \\
\hline
\end{tabular}

Respondents were also asked to compare their overall standard of living with five years ago and give their responses on a scale of 1 to 5 ( 1 being much worse off and 5 much better off). The results in Table 68 show that on average people believe they are about the same (option 3 in the survey) as 5 years ago. The results by gender/marital status demonstrate again that single women have a lower average 
than married men and married women, believing that they are somewhat worse off than 5 years ago, while married people believe they are about the same or a little better off.

The highest correlations between this question and the inner wellbeing domains (Table 69) were 0.356 with economic wellbeing, 0.358 with competence and self-worth and 0.414 with the inner wellbeing average. The lowest was with close relationships and was 0.182 , but all of them were significant at the 0.01 level.

Table 68. Comparison of standard of living with five years ago by gender/marital status

\begin{tabular}{|c|r|c|c|c|}
\hline \multirow{2}{*}{} & \multicolumn{2}{|c|}{ Gender/Marital Status } & \multirow{2}{*}{ Total } \\
\cline { 2 - 5 } & Married Men & $\begin{array}{c}\text { Married } \\
\text { Women }\end{array}$ & $\begin{array}{c}\text { Single } \\
\text { Women }\end{array}$ & Mean \\
\cline { 2 - 5 } & Mean & Mean & Mean & 3.2 \\
\hline $\begin{array}{c}\text { Comparing your standard of living overall } \\
\text { with five years ago, how are you now? }\end{array}$ & $3.4_{\mathrm{a}}$ & $3.3_{\mathrm{a}}$ & $2 . \mathrm{b}_{\mathrm{b}}$ & \\
\hline
\end{tabular}

Note: Values in the same row and sub-table not sharing the same subscript are significantly different at $\mathrm{p}<.05$ in the two-sided test of equality for column means. Cells with no subscript are not included in the test. Tests assume equal variances. Tests are adjusted for all pairwise comparisons within a row of each innermost sub-table using the Bonferroni correction.

Table 69. Correlations comparison of standard of living five years ago with well-being domains

\begin{tabular}{|c|c|c|}
\hline \multicolumn{3}{|c|}{ Correlations } \\
\hline & & $\begin{array}{c}\text { Comparing your } \\
\text { standard of living } \\
\text { overall with five years } \\
\text { ago, how are you now? }\end{array}$ \\
\hline \multirow{2}{*}{ Economic wellbeing } & Pearson Correlation &, $356^{* *}$ \\
\hline & Sig. (2-tailed) & .000 \\
\hline \multirow{2}{*}{$\begin{array}{l}\text { Agency and } \\
\text { participation }\end{array}$} & Pearson Correlation & $266^{\star \star}$ \\
\hline & Sig. (2-tailed) & .000 \\
\hline \multirow{2}{*}{ Social Connections } & Pearson Correlation &, $251^{* \star}$ \\
\hline & Sig. (2-tailed) & .000 \\
\hline \multirow{2}{*}{ Close Relationships } & Pearson Correlation &, $182^{* \star}$ \\
\hline & Sig. (2-tailed) & .000 \\
\hline \multirow{2}{*}{$\begin{array}{l}\text { Physical and mental } \\
\text { health }\end{array}$} & Pearson Correlation & $244^{* *}$ \\
\hline & Sig. (2-tailed) & .000 \\
\hline \multirow{2}{*}{$\begin{array}{c}\text { Competence and self } \\
\text { worth }\end{array}$} & Pearson Correlation &, $358^{\star \star}$ \\
\hline & Sig. (2-tailed) & .000 \\
\hline \multirow{2}{*}{ Values and meaning } & Pearson Correlation &, $302^{* \star}$ \\
\hline & Sig. (2-tailed) & .000 \\
\hline \multirow{2}{*}{$\begin{array}{l}\text { Inner wellbeing } \\
\text { average }\end{array}$} & Pearson Correlation &, $414^{\star \star}$ \\
\hline & Sig. (2-tailed) & .000 \\
\hline
\end{tabular}

**. Correlation is significant at the 0.01 level (2-tailed).

Finally, we asked people how happy they feel (on a scale of 1 very unhappy to 5 very happy) and the results, compared by gender/marital status, are shown in Table 70. On average, people are between being somewhat happy and neither happy nor unhappy, and contrary to the previous sections, there are no gender/marital status differences. In addition, the correlation between how happy people are and the inner wellbeing average is 0.365 . This also correlates significantly with every domain from 0.192 with agency and participation to 0.339 with economic wellbeing (all correlations are significant at 0.01 level) 


\begin{tabular}{|c|c|c|c|c|}
\hline \multirow{2}{*}{} & \multicolumn{2}{|c|}{ Gender/Marital Status } & \multirow{2}{*}{ Subtotal } \\
\cline { 2 - 5 } & $\begin{array}{c}\text { Married } \\
\text { Men }\end{array}$ & $\begin{array}{c}\text { Married } \\
\text { Women }\end{array}$ & $\begin{array}{c}\text { Single } \\
\text { Women }\end{array}$ & Mean \\
\cline { 2 - 5 } & Mean & Mean & Mean & 3.5 \\
\hline $\begin{array}{c}\text { How happy would you say you are } \\
\text { these days? }\end{array}$ & $3,6_{\mathrm{a}}$ & $3,4 \mathrm{a}$ & $3,4 \mathrm{a}$ & \\
\hline
\end{tabular}

Note: Values in the same row and sub-table not sharing the same subscript are significantly different at $\mathrm{p}<$ .05 in the two-sided test of equality for column means. Cells with no subscript are not included in the test. Tests assume equal variances. Tests are adjusted for all pairwise comparisons within a row of each innermost sub-table using the Bonferroni correction.

We also analysed the happiness question by comparing the average scores for each of the asset groups (Table 71) and economic categories based on source of survival (Table 72). The results show that people in higher asset groups and in higher livelihood categories report being happier than those in economically worse off groups. Both economic indicators have a small (but significant at the 0.01 level) correlation with the happiness question, the correlation with asset groups is 0.190 and with economic categories based on main source of survival is 0.176 .

Table 71. Happiness by asset groups

\begin{tabular}{|c|c|c|c|c|c|c|}
\hline & \multicolumn{5}{|c|}{ Asset groups } & \multirow[b]{2}{*}{ Total } \\
\hline & $\begin{array}{c}\text { Group } 1 \\
\text { Asset }\end{array}$ & $\begin{array}{c}\text { Group } 2 \\
\text { Asset }\end{array}$ & $\begin{array}{c}\text { Group 3 } \\
\text { Asset }\end{array}$ & $\begin{array}{c}\text { Group } 4 \\
\text { Asset }\end{array}$ & $\begin{array}{c}\text { Group } 5 \\
\text { Asset }\end{array}$ & \\
\hline & Mean & Mean & Mean & Mean & Mean & Mean \\
\hline $\begin{array}{l}\text { How happy would you say you are } \\
\text { these days? }\end{array}$ & $3.21_{a}$ & $3.58_{b}$ & $3.65_{b}$ & $3.59_{a, b}$ & $3.77_{b}$ & 3,50 \\
\hline
\end{tabular}

Note: Values in the same row and sub-table not sharing the same subscript are significantly different at $p<.05$ in the twosided test of equality for column means. Cells with no subscript are not included in the test. Tests assume equal variances. Tests are adjusted for all pairwise comparisons within a row of each innermost sub-table using the Bonferroni correction.

Table 72. Happiness by economic categories based on main source of survival

\begin{tabular}{|c|c|c|c|c|c|c|}
\hline & \multicolumn{5}{|c|}{ Economic categories based on main source of survival } & \multirow[b]{2}{*}{ Total } \\
\hline & $\begin{array}{c}\text { Group } 1 \\
\text { ECMS }\end{array}$ & $\begin{array}{c}\text { Group } 2 \\
\text { ECMS }\end{array}$ & $\begin{array}{l}\text { Group } 3 \\
\text { ECMS }\end{array}$ & $\begin{array}{c}\text { Group } 4 \\
\text { ECMS }\end{array}$ & $\begin{array}{c}\text { Group } 5 \\
\text { ECMS }\end{array}$ & \\
\hline & Mean & Mean & Mean & Mean & Mean & Mean \\
\hline $\begin{array}{c}\text { How happy would you say you } \\
\text { are these days? }\end{array}$ & $3.33_{a}$ & $3.36 \mathrm{a}$ & $3.63_{a, b}$ & $3.57_{a, b}$ & $4.11_{b}$ & 3.50 \\
\hline
\end{tabular}

Note: Values in the same row and sub-table not sharing the same subscript are significantly different at $\mathrm{p}<.05$ in the twosided test of equality for column means. Cells with no subscript are not included in the test. Tests assume equal variances.

1. Tests are adjusted for all pairwise comparisons within a row of each innermost sub-table using the Bonferroni correction.

After analysing these questions we can now go into the inner wellbeing domains and general scores. As mentioned before, the highest possible score is 5 and the lowest 1 in every domain and in the inner wellbeing average score. The average inner wellbeing score of participants is 3.27 (Table 73), somewhat evenly balanced but tilting a little to the more positive side. However, there are statistically significant differences by gender/marital status. Married men (3.41) have a higher average than married women (3.21), who in turn have a higher average than single women (3.03). Additionally, when looking at each domain, it can be seen that men consistently have higher wellbeing than women, but that women (single vs. married) do not show any statistically significant differences. The only exceptions to this are in the already mentioned overall inner wellbeing score and in economic wellbeing where married men have a higher average (3.25) than married women (3.09) who also have a higher average than single women (2.71). This is consistent with the results showed in previous sections in which single women were shown to experience a worse economic situation. 
Table 73. Wellbeing by gender/marital status

\begin{tabular}{|l|r|r|r|r|}
\hline & \multicolumn{2}{|c|}{ Gender/Marital Status } & \multirow{2}{*}{ Total } \\
\cline { 2 - 5 } & Married Men & $\begin{array}{c}\text { Married } \\
\text { Women }\end{array}$ & $\begin{array}{c}\text { Single } \\
\text { Women }\end{array}$ & Mean \\
\cline { 2 - 5 } & Mean & Mean & Mean \\
\hline Inner wellbeing average & $3.41_{\mathrm{a}}$ & $3.21_{\mathrm{b}}$ & $3.03_{\mathrm{c}}$ & 3.27 \\
\hline Economic wellbeing & $3.25_{\mathrm{a}}$ & $3.09_{\mathrm{b}}$ & $2.71_{\mathrm{c}}$ & 3.10 \\
\hline Agency and participation & $3.17_{\mathrm{a}}$ & $2.80_{\mathrm{b}}$ & $2.63_{\mathrm{b}}$ & 2.93 \\
\hline Social Connections & $3.06_{\mathrm{a}}$ & $2.87_{\mathrm{b}}$ & $2.64_{\mathrm{b}}$ & 2.91 \\
\hline Close Relationships & $3.90_{\mathrm{a}}$ & $3.73_{\mathrm{b}}$ & $3.78_{\mathrm{a}, \mathrm{b}}$ & 3.80 \\
\hline Physical and mental health & $3.62_{\mathrm{a}}$ & $3.41_{\mathrm{b}}$ & $3.23_{\mathrm{b}}$ & 3.47 \\
\hline Competence and self-worth & $3.48_{\mathrm{a}}$ & $3.25_{\mathrm{b}}$ & $3.05_{\mathrm{b}}$ & 3.32 \\
\hline Values and meaning & $3.44_{\mathrm{a}}$ & $3.31_{\mathrm{a}, \mathrm{b}}$ & $3.16_{\mathrm{b}}$ & 3.34 \\
\hline
\end{tabular}

Note: Values in the same row and sub-table not sharing the same subscript are significantly different at $p<.05$ in the two-sided test of equality for column means. Cells with no subscript are not included in the test. Tests assume equal variances. Tests are adjusted for all pairwise comparisons within a row of each innermost sub-table using the Bonferroni correction.

Figure 1: IWB domain scores by Gender/Marital status

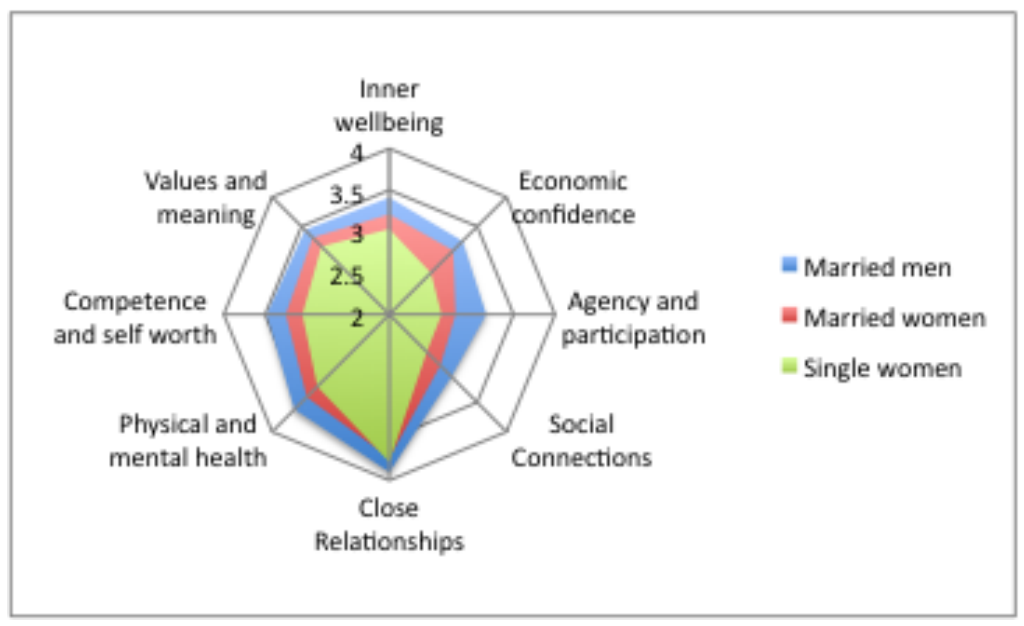

The relationship of school level achieved with inner wellbeing was also analysed. The correlations between school level achieved and the inner wellbeing domains and average are all positive and significant at the 0.01 level (except with close relationships were it is not significant at all). The strongest correlation is with the inner wellbeing average $(0.407)$ and the domains correlate between 0.238 with physical and mental health and 0.339 with agency and participation and competence and self-worth. When comparing school level achieved with each wellbeing average, in every domain (except close relationships) people that have reached higher educational levels express statistically significant higher averages than those with less education (Table 74 . The domains in which the results differ more by school level achieved (in statistically significant differences and net score) are agency and participation, social connections and competence and self-worth, which hint to the impact schooling might have beyond completing education and finding a better job. People with higher education could be in a better position to establish social connections, participate and feel competent in their environment. 


\begin{tabular}{|l|r|r|r|r|r|r|}
\hline \multirow{2}{*}{} & \multicolumn{7}{|c|}{ School level achieved } & \multicolumn{1}{c|}{} \\
\cline { 2 - 6 } & None & $\begin{array}{c}\text { Some } \\
\text { primary } \\
\text { (kinder-7) }\end{array}$ & $\begin{array}{c}\text { Some } \\
\text { lower } \\
\text { secondary } \\
\text { (8-9) }\end{array}$ & $\begin{array}{c}\text { Some } \\
\text { Upper } \\
\text { Secondary } \\
\text { (10-12) }\end{array}$ & Tertiary \\
education & Total \\
\cline { 2 - 7 } & Mean & Mean & Mean & Mean & Mean & Mean \\
\hline Inner wellbeing average & $3,07_{\mathrm{a}}$ & $3,20_{\mathrm{a}}$ & $3,40_{\mathrm{b}}$ & $3,60_{\mathrm{b}, \mathrm{c}}$ & $3,88_{\mathrm{c}}$ & 3,27 \\
\hline Economic wellbeing & $2,82_{\mathrm{a}}$ & $3,02_{\mathrm{a}}$ & $3,31_{\mathrm{b}}$ & $3,43_{\mathrm{b}}$ & $3,58_{\mathrm{b}}$ & 3,09 \\
\hline Agency and participation & $2,69_{\mathrm{a}}$ & $2,83_{\mathrm{a}}$ & $3,02_{\mathrm{a}, \mathrm{b}}$ & $3,42_{\mathrm{b}, \mathrm{c}}$ & $3,78_{\mathrm{c}}$ & 2,93 \\
\hline Social Connections & $2,66_{\mathrm{a}}$ & $2,85_{\mathrm{a}, \mathrm{b}}$ & $3,06_{\mathrm{b}, \mathrm{c}}$ & $3,22_{\mathrm{c}, \mathrm{d}}$ & $3,62_{\mathrm{d}}$ & 2,92 \\
\hline Close Relationships & $3,78_{\mathrm{a}}$ & $3,78_{\mathrm{a}}$ & $3,81_{\mathrm{a}}$ & $3,83_{\mathrm{a}}$ & $4,22_{\mathrm{a}}$ & 3,80 \\
\hline Physical and mental health & $3,32_{\mathrm{a}}$ & $3,40_{\mathrm{a}, \mathrm{c}}$ & $3,61_{\mathrm{a}, \mathrm{b}}$ & $3,76_{\mathrm{b}}$ & $3,94_{\mathrm{b}, \mathrm{c}}$ & 3,47 \\
\hline Competence and self worth & $3,09_{\mathrm{a}}$ & $3,25_{\mathrm{a}, \mathrm{b}}$ & $3,43_{\mathrm{b}, \mathrm{c}}$ & $3,66_{\mathrm{c}, \mathrm{d}}$ & $4,04_{\mathrm{d}}$ & 3,32 \\
\hline Values and meaning & $3,08_{\mathrm{a}}$ & $3,26_{\mathrm{a}}$ & $3,62_{\mathrm{b}}$ & $3,69_{\mathrm{b}}$ & $3,90_{\mathrm{b}}$ & 3,35 \\
\hline
\end{tabular}

Note: Values in the same row and sub-table not sharing the same subscript are significantly different at $p<.05$ in the two-sided test of equality for column means. Cells with no subscript are not included in the test. Tests assume equal variances. Tests are adjusted for all pairwise comparisons within a row of each innermost sub-table using the Bonferroni correction.

Age and IWB domains have very few significant correlations (either at the 0.01 or 0.05 level) (Table 76) the only significant correlations are in economic confidence (-0.125), agency and participation (0.132) and physical and mental health (-0.144). When comparing age groups and gender with each wellbeing average (Table 75), older people express statistically significant lower levels of economic confidence and physical and mental health but higher levels of agency and participation. Low economic confidence could be due to the fact that they are less economically active and more dependent on their families and friends; reduced physical and mental health due to ageing may also play a part in this. However, the more positive attitude to agency and participation may reflect the benefits of age as their opinions may be more respected and listened to as elders in the community. Where there is a statistically significant difference, it is consistently women who express lower levels of wellbeing in every age group. 
Table 75. Inner wellbeing by age groups and gender

\begin{tabular}{|c|c|c|c|c|c|c|c|c|c|c|c|c|}
\hline & \multicolumn{10}{|c|}{ Age groups } & \multirow{2}{*}{\multicolumn{2}{|c|}{ Total }} \\
\hline & \multicolumn{2}{|c|}{18 to 29 years } & \multicolumn{2}{|c|}{30 to 34 years } & \multicolumn{2}{|c|}{35 to 39 years } & \multicolumn{2}{|c|}{40 to 49 years } & \multicolumn{2}{|c|}{50 and up } & & \\
\hline & \multicolumn{2}{|c|}{ Gender } & \multicolumn{2}{|c|}{ Gender } & \multicolumn{2}{|c|}{ Gender } & \multicolumn{2}{|c|}{ Gender } & \multicolumn{2}{|c|}{ Gender } & \multicolumn{2}{|c|}{ Gender } \\
\hline & Male & Female & Male & Female & Male & Female & Male & Female & Male & Female & Male & Female \\
\hline & Mean & Mean & Mean & Mean & Mean & Mean & Mean & Mean & Mean & Mean & Mean & Mean \\
\hline Inner wellbeing average & $3,39_{a}$ & $3,19_{b}$ & $3,39 a$ & $3,29_{a}$ & $3,40_{a}$ & $3,27 a$ & $3,54_{a}$ & $3,20_{b}$ & $3,29_{a}$ & $3,00_{b}$ & 3.41 & 3.20 \\
\hline Economic wellbeing & $3,32_{a}$ & $3,10_{a}$ & $3,14 a$ & $3,20_{a}$ & $3,21_{a}$ & $3,20_{a}$ & $3,40_{a}$ & $2,98_{b}$ & $3,01_{a}$ & $2,66_{b}$ & 3.21 & 3.06 \\
\hline Agency and participation & $2,99_{a}$ & $2,62_{b}$ & $3,07 a$ & $2,86_{a}$ & $3,14 a$ & $2,90 a$ & $3,35 a$ & $2,83_{b}$ & $3,10_{a}$ & $2,75 b$ & 3.16 & 2.79 \\
\hline Social connections & $3,06_{a}$ & $2,86_{a}$ & $3,03 a$ & $2,95 a$ & $2,95 a$ & $2,83 a$ & $3,30 a$ & $2,91_{b}$ & $2,95 a$ & $2,68_{a}$ & 3.07 & 2.86 \\
\hline Close relationships & $3,84_{a}$ & $3,72_{a}$ & $3,89_{a}$ & $3,86_{a}$ & $3,90_{a}$ & $3,73_{a}$ & $4,03_{a}$ & $3,70_{b}$ & $3,81_{a}$ & $3,73_{a}$ & 3.91 & 3.75 \\
\hline Physical and mental health & $3,81_{a}$ & $3,55_{a}$ & $3,66_{a}$ & $3,43 a$ & $3,61_{a}$ & $3,49 a$ & $3,65 a$ & $3,31_{b}$ & $3,45_{a}$ & $3,14 a$ & 3.61 & 3.41 \\
\hline $\begin{array}{l}\text { Competence and self- } \\
\text { worth }\end{array}$ & $3,41_{a}$ & $3,18 a$ & $3,47 a$ & $3,26_{a}$ & $3,54 a$ & $3,30 a$ & $3,55 a$ & $3,32 \mathrm{~b}$ & $3,38_{a}$ & $2,99 b$ & 3.48 & 3.23 \\
\hline Values and meaning & $3,53_{a}$ & $3,36 a$ & $3,52 a$ & $3,30_{a}$ & $3,43 a$ & $3,41_{a}$ & $3,58 \mathrm{a}$ & $3,34 a$ & $3,30_{a}$ & $3,05 a$ & 3.46 & 3.31 \\
\hline
\end{tabular}

Note: Values in the same row and sub-table not sharing the same subscript are significantly different at $p<.05$ in the two-sided test of equality for column means. Cells with no subscript are not included in the test. Tests assume equal variances. Tests are adjusted for all pairwise comparisons within a row of each innermost sub-table using the Bonferroni correction. 
Table 76. Age and wellbeing correlations. Inner wellbeing

\begin{tabular}{|c|c|c|}
\hline \multicolumn{3}{|c|}{ Correlations } \\
\hline & & Age \\
\hline \multirow{2}{*}{ Economic wellbeing } & Pearson Correlation &,$- 156^{* *}$ \\
\hline & Sig. (2-tailed) & .004 \\
\hline \multirow{2}{*}{$\begin{array}{l}\text { Agency and } \\
\text { participation }\end{array}$} & Pearson Correlation & .096 \\
\hline & Sig. (2-tailed) & .074 \\
\hline \multirow{2}{*}{ Social Connections } & Pearson Correlation & -.034 \\
\hline & Sig. (2-tailed) & .529 \\
\hline \multirow{2}{*}{ Close Relationships } & Pearson Correlation & -.030 \\
\hline & Sig. (2-tailed) & .576 \\
\hline \multirow{2}{*}{$\begin{array}{l}\text { Physical and mental } \\
\text { health }\end{array}$} & Pearson Correlation &,$- 186^{\star \star}$ \\
\hline & Sig. (2-tailed) & .000 \\
\hline \multirow{2}{*}{$\begin{array}{l}\text { Competence and self } \\
\text { worth }\end{array}$} & Pearson Correlation & -.016 \\
\hline & Sig. (2-tailed) & .769 \\
\hline \multirow{2}{*}{ Values and meaning } & Pearson Correlation & -.088 \\
\hline & Sig. (2-tailed) & .098 \\
\hline \multirow{2}{*}{$\begin{array}{l}\text { Inner wellbeing } \\
\text { average }\end{array}$} & Pearson Correlation & -.073 \\
\hline & Sig. (2-tailed) & .184 \\
\hline
\end{tabular}

${ }^{* *}$. Correlation is significant at the 0.01 level (2-tailed).

Economic groups based on main source of survival and IWB correlate significantly and positively with each other (at the 0.01 level), albeit not so strongly. Inner wellbeing average has a correlation of 0.371 with the livelihoods groupings, and the domain correlations are: 0.286 with economic confidence, 0.328 with agency and participation, 0.223 with social connections, 0.186 with close relationships, 0.237 with physical and mental health, 0.339 with competence and self-worth and 0.201 with values and meaning. Additionally, in Table 74 these correlations become clear as people in higher economic categories have statistically significantly higher levels of wellbeing in every domain. The biggest differences in scores from Group 5 to Group 1 are found in agency and participation and in competence and self-worth. This could mean that a higher economic status enables people to have a greater say and participate more actively in community affairs. Having a relatively stable source of survival would also seem good for the sense of competence and self-worth. In contrast, people with precarious livelihoods may not have the time to participate in community affairs due to having to spend more time in securing multiple sources of income and may also be marginalised due to their poverty. 
Table 77. Economic groups and inner wellbeing

\begin{tabular}{|c|c|c|c|c|c|c|}
\hline & \multicolumn{5}{|c|}{$\begin{array}{c}\text { Economic categories based on main source } \\
\text { of survival }\end{array}$} & \multirow[b]{2}{*}{ Total } \\
\hline & $\begin{array}{c}\text { Group } \\
1 \\
\text { ECMS }\end{array}$ & $\begin{array}{c}\text { Group } \\
2 \\
\text { ECMS }\end{array}$ & $\begin{array}{c}\text { Group } \\
3 \\
\text { ECMS }\end{array}$ & $\begin{array}{c}\text { Group } \\
4 \\
\text { ECMS }\end{array}$ & $\begin{array}{c}\text { Group } \\
5 \\
\text { ECMS }\end{array}$ & \\
\hline & Mean & Mean & Mean & Mean & Mean & Mean \\
\hline Inner wellbeing average & $3,14 \mathrm{a}$ & $3,16 a$ & $3,30_{a, b}$ & $3,42_{b}$ & $3,94_{c}$ & 3,27 \\
\hline Economic wellbeing & $2,94 a$ & $2,97 \mathrm{a}$ & $3,09_{a, b}$ & $3,36_{b, c}$ & $3,67_{c}$ & 3,09 \\
\hline Agency and participation & $2,56 a$ & $2,87_{b}$ & $2,98 b$ & $3,03_{b}$ & $3,91_{c}$ & 2,93 \\
\hline Social connections & $2,85 a$ & $2,79 a$ & $2,96 a$ & $3,00_{a}$ & $3,62_{b}$ & 2,92 \\
\hline Close relationships & $3,77_{a, b}$ & $3,72_{a}$ & $3,79_{a, b}$ & $3,96 b, c$ & $4,21_{c}$ & 3,80 \\
\hline Physical and mental health & $3,37_{\mathrm{a}, \mathrm{b}}$ & $3,34_{a}$ & $3,51_{a, b}$ & $3,66_{b, c}$ & $4,01_{\mathrm{c}}$ & 3,47 \\
\hline Competence and self-worth & $3,05_{a}$ & $3,23_{a, b}$ & $3,39_{b}$ & $3,46_{b, c}$ & $3,99_{d}$ & 3,32 \\
\hline Values and meaning & $3,34 a$ & $3,20_{a}$ & $3,35_{a}$ & $3,47_{\mathrm{a}}$ & $4,10_{b}$ & 3,35 \\
\hline
\end{tabular}

Asset groups and IWB scores correlate significantly and positively with each other, and have a stronger correlation than in the previous case. The inner wellbeing average has a correlation of 0.451 , and the domain correlations are: 0.448 with economic confidence, 0.334 with agency and participation, 0.324 with social connections, 0.130 with close relationships, 0.125 with physical and mental health, 0.408 with competence and self-worth and 0.331 with values and meaning (all correlations are significant at the 0.01 level except for close relationships and physical and mental health which are significant at the 0.05 level). In Table 75, it becomes clear that respondents with more assets have significantly higher levels of wellbeing in every domain, although the scores of Groups 4 and 5 are not as high as the ones from the economic categories based on source of survival groups. The domain with the biggest score differences between Group 5 and 1 is economic confidence where a clear and statistically significant increase can be seen in every group from 1 to $4 / 5$.

Table 78. Asset groups and inner wellbeing

\begin{tabular}{|l|r|r|r|r|r|r|}
\hline \multirow{2}{*}{} & \multicolumn{4}{|c|}{ Assets recoded into 5 groups } & \multirow{2}{*}{ Total } \\
\cline { 2 - 6 } & $\begin{array}{c}\text { Group } \\
\text { 1 Asset }\end{array}$ & $\begin{array}{c}\text { Group } \\
\text { 2 Asset }\end{array}$ & $\begin{array}{c}\text { Group } \\
\text { 3 Asset }\end{array}$ & $\begin{array}{c}\text { Group } \\
\text { 4 Asset }\end{array}$ & $\begin{array}{c}\text { Group } \\
\text { 5 Asset }\end{array}$ & \\
\cline { 2 - 6 } & Mean & Mean & Mean & Mean & Mean & Mean \\
\hline Inner wellbeing average & $3,05_{\mathrm{a}}$ & $3,25_{\mathrm{b}}$ & $3,34_{\mathrm{b}, \mathrm{c}}$ & $3,51_{\mathrm{c}, \mathrm{d}}$ & $3,68_{\mathrm{d}}$ & 3.25 \\
\hline Economic wellbeing & $2,77_{\mathrm{a}}$ & $3,06_{\mathrm{b}}$ & $3,18_{\mathrm{b}, \mathrm{c}}$ & $3,45_{\mathrm{c}, \mathrm{d}}$ & $3,68_{\mathrm{d}}$ & 3,09 \\
\hline Agency and participation & $2,64_{\mathrm{a}}$ & $2,91_{\mathrm{b}}$ & $3,03_{\mathrm{b}, \mathrm{c}}$ & $3,20_{\mathrm{b}, \mathrm{c}}$ & $3,41_{\mathrm{c}}$ & 2,93 \\
\hline Social connections & $2,68_{\mathrm{a}}$ & $2,90_{\mathrm{a}, \mathrm{b}}$ & $3,00_{\mathrm{b}}$ & $3,09_{\mathrm{b}, \mathrm{c}, \mathrm{d}}$ & $3,37_{\mathrm{d}}$ & 2,92 \\
\hline Close relationships & $3,68_{\mathrm{a}}$ & $3,85_{\mathrm{a}}$ & $3,86_{\mathrm{a}}$ & $3,89_{\mathrm{a}}$ & $3,87_{\mathrm{a}}$ & 3,80 \\
\hline Physical and mental health & $3,37_{\mathrm{a}}$ & $3,47_{\mathrm{a}}$ & $3,49_{\mathrm{a}}$ & $3,59_{\mathrm{a}}$ & $3,62_{\mathrm{a}}$ & 3,47 \\
\hline Competence and self-worth & $3,05_{\mathrm{a}}$ & $3,26_{\mathrm{b}}$ & $3,44_{\mathrm{b}, \mathrm{c}}$ & $3,57_{\mathrm{c}, \mathrm{d}}$ & $3,79_{\mathrm{d}}$ & 3,32 \\
\hline Values and meaning & $3,15_{\mathrm{a}}$ & $3,31_{\mathrm{a}}$ & $3,28_{\mathrm{a}}$ & $3,68_{\mathrm{b}}$ & $3,99_{\mathrm{b}}$ & 3,35 \\
\hline
\end{tabular}

Note: Values in the same row and sub-table not sharing the same subscript are significantly different at $p<.05$ in the twosided test of equality for column means. Cells with no subscript are not included in the test. Tests assume equal variances. Tests are adjusted for all pairwise comparisons within a row of each innermost sub-table using the Bonferroni correction.

The wellbeing scores with the most significant variables demonstrate that gender/ marital status, school level, age, wealth (as a proxy for asset groups) and income (as a proxy of economic categories based on main source of survival) are the elements that make a difference in people's wellbeing. 


\section{Conclusions}

The findings from the second round of data collection show that living conditions in Chiawa remain very poor. Whilst the younger generation is achieving higher school levels than their elders, in general terms school achievement levels are low. Families have few assets, and many experience deprived living conditions. Drilling down into the data we can see that respondents' gender and marital status are the most significant factor in differences across almost all variables. Married men are better off economically, have reached higher levels of education, have fewer health problems and report higher levels of wellbeing. Single women, on the other hand, experience the harshest conditions; they report worse living conditions, are worse off economically and experience lower levels of wellbeing.

Looking at the subjective indicators of inner wellbeing (IWB), respondents report medium/positive scores of wellbeing - an average of 3.27 out of a maximum of 5. Respondents rate their wellbeing as higher in the domains of close relationships and physical and mental health, but lower in other domains, particularly social connections. However, care needs to be exercised in interpreting these scores. Issues such as social desirability bias (saying what you think will make you look good) may affect different domains differently, and so give an underlying structure to mean scores. A more robust form of analysis is to look at how scores within domains differ by different respondent characteristics. This shows that gender and marital status, age, school level, assets and economic position affect inner wellbeing: what people think and feel they are able to be and do.

This report presents the preliminary analysis of the data while a more detailed analysis of the evidence will follow in forthcoming papers. 


\section{References}

White, S. C., O. Gaines, S., Jha, S., Marshall, N., Graveling, E. (2012a). Wellbeing Pathways Report: Zambia Round 1. University of Bath: Centre for Development Studies.

White, S. C., O. Gaines, S., Jha, S., Marshall, N. (2012b). Wellbeing Pathways Report: India Round 1. University of Bath: Centre for Development Studies.

White, S., Gaines, S., Jr., \& Jha, S. (2013). Inner Wellbeing: Concept and Validation of a New Approach to Subjective Perceptions of Wellbeing_India. Social Indicators Research, 1-24. doi: 10.1007/s11205013-0504-7 


\section{Brunel UNIVERSITY

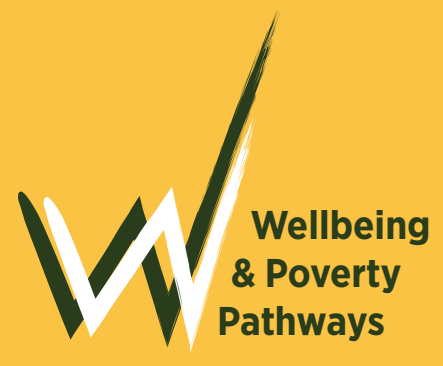

An ESRC/DFID Research Project
Wellbeing and Poverty Pathways is an international research partnership exploring the links between poverty and wellbeing through research in rural communities in Zambia and India. The partnership involves:

- University of Bath, UK

- $\quad$ Brunel University, UK

- G.B.Pant Institute, India

- Oxfam Hong Kong

- HODI, Zambia

- Chaupal, India

For further information, visit www.wellbeingpathways.org or email wellbeing-pathways@bath.ac.uk
This work was supported by the Economic and Social Research Council/ Department for International Development Joint Scheme for Research on International Development (Poverty Alleviation) grant number RES-167-25-0507 ES/H033769/1 